Review

\title{
Applications of Technological Solutions in Primary Ways of Preventing Transmission of Respiratory Infectious Diseases- A Systematic Literature Review
}

\author{
Gleidson Sobreira Leite*(D), Adriano Bessa Albuquerque and Plácido Rogerio Pinheiro (D)
}

check for

updates

Citation: Leite, G.S.; Albuquerque, A.B.; Pinheiro, P.R. Applications of Technological Solutions in Primary Ways of Preventing Transmission of Respiratory Infectious Diseases-A Systematic Literature Review. Int. J Environ. Res. Public Health 2021, 18, 10765. https://doi.org/10.3390/ ijerph182010765

Academic Editor: Paul B. Tchounwou

Received: 11 August 2021

Accepted: 11 October 2021

Published: 14 October 202

Publisher's Note: MDPI stays neutral with regard to jurisdictional claims in published maps and institutional affiliations.

Copyright: (c) 2021 by the authors. Licensee MDPI, Basel, Switzerland. This article is an open access article distributed under the terms and conditions of the Creative Commons Attribution (CC BY) license (https:// creativecommons.org/licenses/by/ $4.0 /)$.
UNIFOR, Department of Computer Science, University of Fortaleza, Fortaleza 60811-905, CE, Brazil; adrianoba@unifor.br (A.B.A.); placido@unifor.br (P.R.P.)

* Correspondence: gleidson.sleite@gmail.com

\begin{abstract}
With the growing concern about the spread of new respiratory infectious diseases, several studies involving the application of technology in the prevention of these diseases have been carried out. Among these studies, it is worth highlighting the importance of those focused on the primary forms of prevention, such as social distancing, mask usage, quarantine, among others. This importance arises because, from the emergence of a new disease to the production of immunizers, preventive actions must be taken to reduce contamination and fatalities rates. Despite the considerable number of studies, no records of works aimed at the identification, registration, selection, and rigorous analysis and synthesis of the literature were found. For this purpose, this paper presents a systematic review of the literature on the application of technological solutions in the primary ways of respiratory infectious diseases transmission prevention. From the 1139 initially retrieved, 219 papers were selected for data extraction, analysis, and synthesis according to predefined inclusion and exclusion criteria. Results enabled the identification of a general categorization of application domains, as well as mapping of the adopted support mechanisms. Findings showed a greater trend in studies related to pandemic planning and, among the support mechanisms adopted, data and mathematical application-related solutions received greater attention. Topics for further research and improvement were also identified such as the need for a better description of data analysis and evidence.
\end{abstract}

Keywords: healthcare; infectious disease; information technology; literature review; transmission prevention

\section{Introduction}

According to Baldominus et al. [1], infectious diseases are the result of the invasive action of microscopic organisms (e.g., bacteria or viruses) in the body, and may be presented in many different types with different effect ranges. For example, while some infected bodies can remain asymptomatic, others can reach high risks of death.

Given the importance of the issue and its impact on human life, medicine has developed a variety of mechanisms for the prevention, prediction, diagnosing and treatment of infections [1]. However, over the years, new microorganisms have emerged, generating constant challenges for science in combating the action of these organisms towards humanity.

An important example of this scenario is the current pandemic crisis brought about by the new coronavirus (SARS-CoV-2), responsible for COVID-19 disease. Discovered in Wuhan and rapidly spread since December 2019 within China to other countries of the world [2,3], the newly identified coronavirus has generated considerable challenges both in terms of safety in public health, as well as economic and social impacts to society [4]. 
Due to the high occurrence rate, as well as severe health symptoms and high fatalities worldwide, on 31 January 2020, the World Health Organization (WHO) announced a global pandemic and on 11th March, the COVID-19 disease was recognized as a pandemic [5].

Since then, the number of cases and fatalities have been constantly making headlines around the world, where on 9 August 2021, the number of confirmed COVID-19 cases reached over 203 million with more than 213 countries and regions affected by the pandemic $[6,7]$.

Figure 1 presents the evolution of the total cumulative count of identified COVID-19 cases around the world in the period of 22 January 2020 to 1 August 2021, and Figure 2 presents the evolution of the total number of deaths around the world in the period of 23 January 2020 to 1 August 2021.

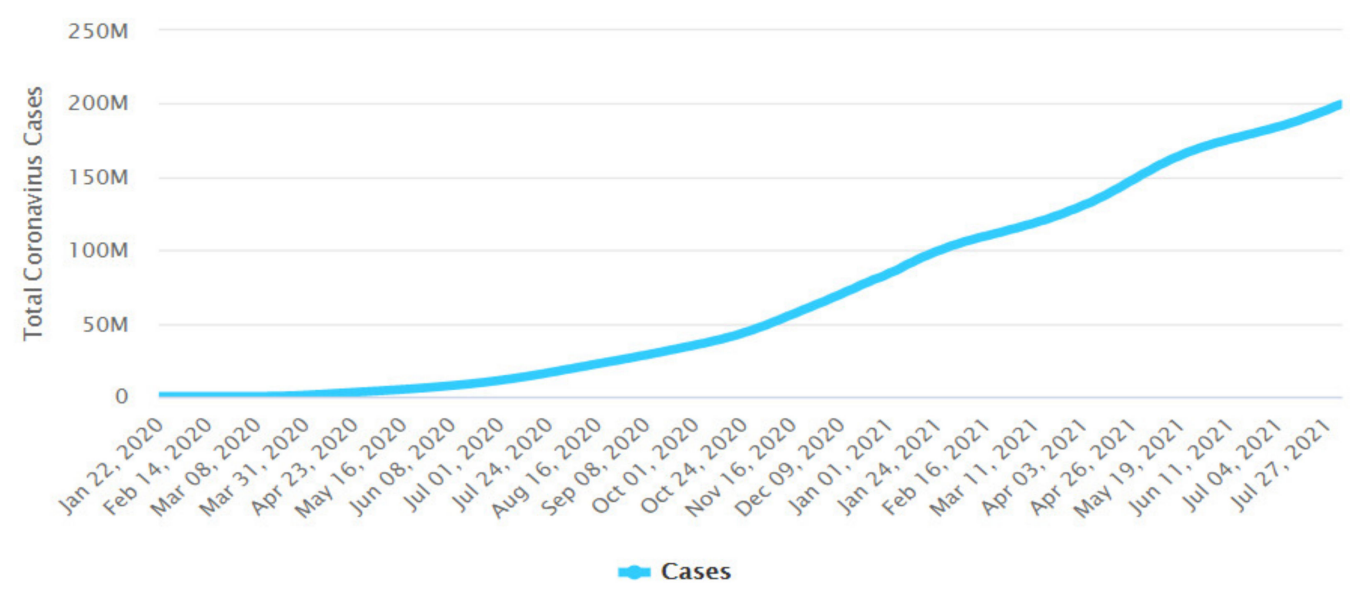

Figure 1. Total cumulative count of coronavirus cases $(199,560,514)$ worldwide. Period: 22 January 2020 to 1 August 2021. Publication date: 2 August 2021. Source: https:/ / www.worldometers.info/ coronavirus/worldwide-graphs/\#case-distribution (accessed on 4 August 2021).

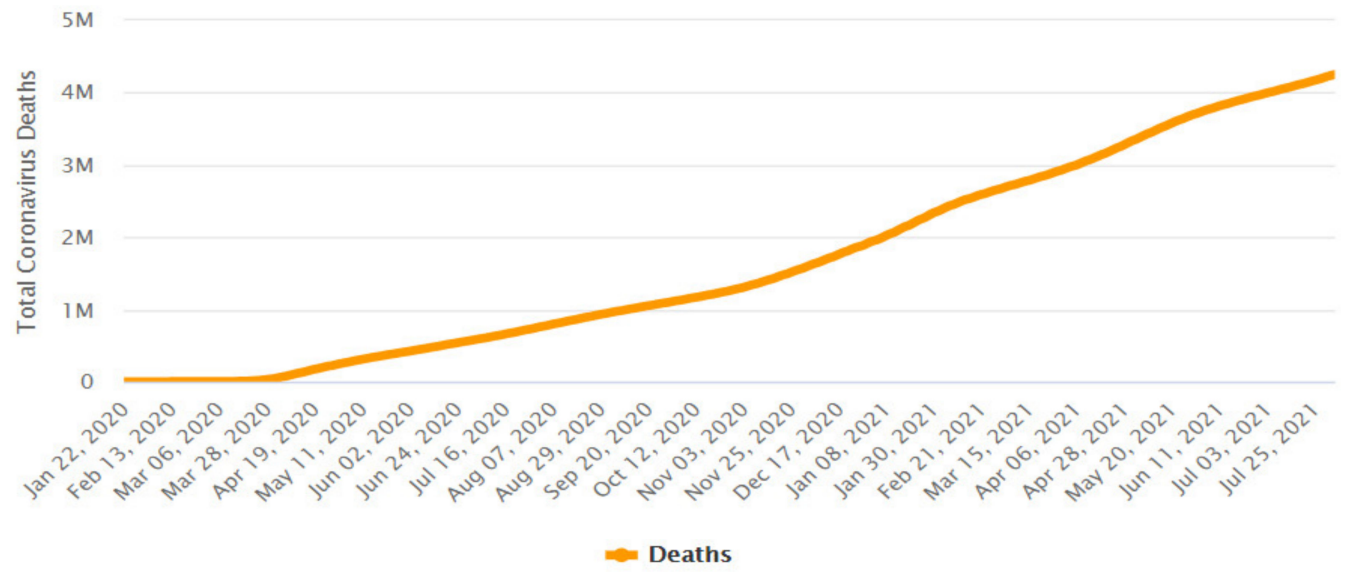

Figure 2. Total cumulative count of deaths caused by coronavirus $(4,240,374)$ worldwide. Period: 23 January 2020 to 1 August 2021. Publication date: 2 August 2021. Source: https:/ / www.worldometers. info/coronavirus/worldwide-graphs/\#case-distribution (accessed on 4 August 2021).

From the emergence of new infectious diseases, new research studies are also being carried out in order to contribute to their treatment motivated not only because of health crisis, but also social and economic impacts. However, until new medications or vaccines are produced, preventive measures are recommended by health organizations in order to reduce transmission among the population, such as social distancing, mask usage, isolation and quarantine [8-10].

Being a topic of considerable importance, especially due to the social, health and economic impacts to society, studies focused on the application of technology in the 
primary forms of prevention of new infectious diseases have attracted much attention and concern from institutions and researchers.

Despite the existence of several publications presenting approaches and different uses of technology in this context, to the best of our knowledge, there are no records of research aimed at the identification, registration, selection, and rigorous analysis and synthesis of this literature.

Additionally, due to the large volume of studies, and the fact that they are published in several conferences and journals, it is difficult to locate these works.

To assist current and future researchers in discovering these studies, as well as to identify, select, rigorously analyze, and synthesize this literature, a systematic literature review (SLR) is presented in this paper.

The scope of this SLR was to identify relevant studies that adopt information technology solutions in the primary ways of preventing respiratory infectious diseases transmission/spread.

This study also aims to assist in understanding what is being carried out and studied, discovering new directions, as well as having a better understanding of how technologies are being used in the context proposed in this work, its main objectives, support mechanisms adopted, level of evidence reported, gaps that need to be deepened in research, as well as to organize the knowledge to support the technological transition.

In this paper, the design, execution and findings of a systematic review of the literature are presented, aiming at a systematic identification, selection and summarization of a comprehensive set of approaches that adopt technological solutions in the primary ways of respiratory infectious diseases transmission prevention.

In this review, 219 relevant papers (from 1139 initially retrieved) were selected and rigorously analyzed performing data extraction, analysis, and synthesis according to predefined inclusion and exclusion criteria, in order to answer a set of research questions that motivated this review.

The SLR took place in three stages. In the first one, a proposed search string (see Section 3.2.2) was executed in four digital libraries obtaining 1139 papers. In the second stage, an initial filter was performed in the title, keywords and abstract of the studies, applying the inclusion and exclusion criteria (see Section 3.3) resulting in 239 articles. Finally, performing a full text reading of the remaining articles, the inclusion and exclusion criteria were applied again, resulting in the 219 relevant studies.

From the findings, it was possible to identify six application domain categories in which there was a greater trend in studies related to pandemic planning and, among the support mechanisms adopted, data and mathematical application-related solutions received greater attention.

The two significant contributions of this study are:

- This work presents the design, execution, and results of a comprehensive systematic literature review of relevant studies on information technology applications in the primary ways of new respiratory infectious diseases transmission prevention. The study was based on predefined selection criteria, where rigorous analysis and synthesis of the approaches and associated support mechanisms were carried out, reporting the evidence in an easily accessible format.

- In this study, the approaches, support mechanisms and available evidence were structured and classified using different formats that are expected to be useful to practitioners and researchers. It is also expected that the findings will also identify issues relevant to interested researchers, and that can be used as an evidence-based guide to select appropriate technologies, approaches, solutions, or support mechanisms based on the different needs or scenarios. 


\section{Background and Related Work}

Having an important role in several actions in support of treatment, combat and prevention of new infectious diseases, the adoption of information technology in this scenario has attracted great attention and concern from researchers and practitioners.

However, concerning new infectious diseases that may emerge, until the production of immunizers or medications that will make their treatment possible, preventive actions must be taken by the population to reduce the rates of contamination and fatalities, such as social distancing, mask usage, isolation, or quarantine [8-10].

To this end, several research studies have been proposed and carried out regarding the application of technology in this context, as mentioned by Chen et al. [11], who conducted a review on the developments and challenges of current contact tracing technologies. According to Chen et al. [11], contact tracking is one of the key technologies that may be adopted in the prevention and control of infectious diseases, which may be helpful in the location and isolation of infected people and high-risk individuals, preventing further spread of the diseases.

Also, in the line of contact tracing study, Ahmed et al. [12] presented an overview of proposed tracing app examples adopted in the fight against COVID-19, discussing the concerns reported by users regarding their usage, and outlining potential research directions for next-generation app design. Regarding challenges and future directions of contact tracing in the assistance of the fight against coronavirus, Chowdhury et al. [13] reviewed data-driven solutions and apps to identify their strength and weakness, and Hasaini et al. [14] presented a literature review of contact tracing approaches and applications adopted in governments around the world to monitor and control the spread of the COVID-19 disease.

According to Ricci et al. [15], several blockchain studies are also emerging in order to assist in the fight against COVID-19. In a survey conducted by the author, ways in which blockchain technology can be useful in supporting health actions were presented, including in contact tracing and vaccine support.

Regarding machine learning applications, Chamola et al. [16] provided a review of several machine learning algorithms that can be adopted in disaster and pandemic management, also presenting a tutorial on machine learning algorithms. Mathematical models, including compartment, statistical and machine learning models for COVID-19 transmission and diagnosis were also reviewed in a work presented by John et al. [17].

Other researches related to data science are also emerging in terms of applications in the prevention of infectious diseases. Regarding Big data, Sudana et al. [18] performed an analysis of the use of Big Data in the health domain in order to identify the benefits of its application in preventing the spread of infectious diseases such as Tuberculosis. A survey of the state of the art of researches based on data science process application for Dengue infection combat was also carried out by Siriyasatien et al. [19]. The work presented some issues to be explored and analyzed such as data sources, data preparation and representation techniques, and forecasting models.

Deep learning-based techniques were analyzed in a survey performed by Ikram et al. [20], which are classical techniques that can be used to detect COVID-19 Standard Operating Procedures (SOP), such as wearing masks or social distancing, were explored.

Studies that adopt Internet of Things Technologies have also been gaining space in actions applied in the health domain and prevention of infectious diseases. In a review carried out by Manavi et al. [21], the authors explored various Internet of Things technologies and applications adopted in contact tracing, screening, and surveillance, aiming to provide an overall understanding of the identified solutions in the fight against COVID-19.

Regarding Computational Intelligence applications, Baldominos et al. [1] performed a systematic literature review aiming to find studies that adopted computational intelligence to predict infections in patients using physiological data as features. The study analyzed 101 relevant documents between the period of 2003 and 2019, showed that automatic diagnosis of these diseases is well documented in medical literature and concluded that 
sepsis, Clostridium difficile infection and surgical site infections were the most addressed. Most of the identified studies adopted machine learning techniques.

Focusing on wearable devices, unobtrusive sensing systems and telehealth technologies, Ding et al. [22] presented a review on technologies and systems with various application scenarios for handling the COVID-19, and, regarding applications (apps and systems) developed by Government Institutions, Private Firms, and Individual Citizens across the world, Gupta et al. [23] performed a survey encompassing more than 100 apps to identify the different categories where technology is being used for decision making. The major areas of application covered in the study were Contact Tracing, Social Distancing, Mask Detection, Information Searching, Big Data, among others.

Regarding digital interventions for fighting COVID-19, Nazrul and Najmul Islam [24] performed a review to compare the Bangladeshi perspective with other countries. As the topic was still emerging and there was not much academic literature available, the authors reviewed online content using Google and Yahoo search engines. A total of 57 online e-resources were found, including news and blogs articles, web contents of organizations and online press releases. After identifying some digital interventions in the fight against COVID-19, both in different parts of the world and in Bangladesh, a comparative analysis was carried out and areas were proposed where Bangladesh could focus to strengthen the fight against COVID-19.

Also considering applications of technology in the COVID-19 pandemic scenario, Whitelaw et al. [25] made available a viewpoint with a framework for the application of digital technologies in pandemic management and response. The authors highlighted successful technologies applications in different countries regarding pandemic planning, surveillance, quarantine, health care, contact tracing and testing.

Thus, over time, several surveys and reviews focused on technical solutions to provide assistance in the fight against infectious diseases have appeared in conferences or journals. However, to the best of our knowledge, there were no records of works aimed at systematic reviewing (identifying, selecting, rigorously analyzing and synthesizing) the literature focusing on the application of technological solutions in the primary ways of respiratory infectious diseases transmission prevention.

Through this systematic literature review, we are interested in finding out what technological solutions and support mechanisms are available in scientific works, and how they can contribute to the primary forms of prevention of the spread of new respiratory infectious diseases.

This work is structured as follows: in Section 3, the systematic literature review method is described and the review protocol is defined. Demographic information, quality assessment and research questions analysis are presented in Section 4. Threats to the validity, implications and limitations are discussed in Section 5 and, finally, conclusions are presented in Section 6.

\section{Research Method}

Being one of the most widely used research methods in Evidence-Based Software Engineering (EBSE), the Systematic Literature Review (SLR) provides a well-defined process for identifying, evaluating, and interpreting all available evidence relevant to a specific research question or topic, as well as evaluates existing studies on a specific phenomenon in a fair and credible manner [26].

This study was performed following the guidelines of Kitchenhamet et al. [26] involving three main phases: definition of a review protocol, conduction of the review and the review report. The adopted review protocol consists of the following elements: (i) research questions, (ii) search strategy, (iii) inclusion and exclusion criteria, (iv) study selection, (v) evaluation of study quality and (vi) data extraction and synthesis, which will be discussed in the following subsections. 


\subsection{Research Questions}

Through this systematic literature review, the aim is to summarize and provide an overview of current research on "which approaches that adopted information technology in the primary ways of prevention of respiratory infectious diseases were reported in the peer-reviewed literature?". For this, a set of research questions (RQs) were formulated (see Table 1) in order to be answered through this SLR.

Table 1. Proposed research questions (RQ).

\begin{tabular}{|c|c|}
\hline Research Question & Motivation \\
\hline $\begin{array}{l}\text { RQ1: Which approaches have been adopted or } \\
\text { suggested in the primary ways of preventing } \\
\text { respiratory infectious diseases using } \\
\text { information technology solutions? }\end{array}$ & $\begin{array}{l}\text { The purpose is to identify infectious diseases } \\
\text { transmission prevention approaches that are } \\
\text { proposed or applied with the use of } \\
\text { information technology }\end{array}$ \\
\hline & $\begin{array}{l}\text { Identify the application domains of the } \\
\text { approaches. With this information, researchers }\end{array}$ \\
\hline $\begin{array}{l}\text { RQ2: What are the application domains of the } \\
\text { identified approaches? }\end{array}$ & $\begin{array}{c}\text { and practitioners can identify the application } \\
\text { domains that have gained the most interest in } \\
\text { the primary forms of prevention of } \\
\text { infectious diseases }\end{array}$ \\
\hline & $\begin{array}{l}\text { What technologies, systems, techniques, } \\
\text { among other mechanisms have been proposed } \\
\text { or adopted to support or achieve the objectives }\end{array}$ \\
\hline $\begin{array}{l}\text { RQ3: Which support mechanisms are proposed } \\
\text { or used? }\end{array}$ & $\begin{array}{l}\text { of the approaches? This knowledge can help } \\
\text { practitioners and/or researchers in the } \\
\text { identification of trends in the use of } \\
\text { technological solutions as } \\
\text { support mechanisms. }\end{array}$ \\
\hline $\begin{array}{l}\text { RQ4: How much evidence to support the } \\
\text { adoption of the approaches is available? }\end{array}$ & $\begin{array}{l}\text { Obtain knowledge about the maturity of the } \\
\text { identified approaches, in order to assist } \\
\text { researchers and practitioners in further } \\
\text { adoption or evaluation of existing approaches } \\
\text { in this systematic review, maturity was } \\
\text { measured based on levels of evidence } \\
\text { (see Section 3.4). }\end{array}$ \\
\hline RQ5: Which contexts are addressed? & $\begin{array}{c}\text { Identify the contexts (academy or industry) in } \\
\text { which the studies were applied, validated or } \\
\text { evaluated. For industrial context, real case data } \\
\text { or evaluation in real case scenarios is } \\
\text { considered. If validations were described in } \\
\text { both contexts, the industrial context is } \\
\text { considered for the purpose of evaluating } \\
\text { the works. }\end{array}$ \\
\hline
\end{tabular}

The questions were defined in order to cover the objectives of this SLR, which are: identifying what approaches have been adopted or suggested in the primary ways of preventing respiratory infectious diseases using information technology solutions (RQ1), identification of the application domains of the approaches (RQ2), identification of which support mechanisms are proposed or used (RQ3), how much evidence to support the adoption of the approaches is available (RQ4), and the addressed contexts (RQ5).

The answers to these questions can provide systematic insight and overview to researchers and practitioners regarding approaches and support mechanisms proposed in scientific studies, also helping to identify missing gaps and opportunities for improvement.

\subsection{Search Strategy}

According to Kitchenhamet et al. [26], in order to help researchers to get as many relevant studies as possible, the search strategy is essential. In this SLR, the research was conducted with various combinations of derivative terms related to the subject of the 
study, where the adopted search strategy was composed of the following elements: search method, search items and data sources.

\subsubsection{Search Method}

For the search strategy, automatic searches on electronic database engines or digital libraries (listed in Table 2) were performed using the search terms presented in Section 3.2.2.

Table 2. Electronic databases adopted in the automatic searches.

\begin{tabular}{cccc}
\hline $\begin{array}{c}\text { Electronic } \\
\text { Database }\end{array}$ & $\begin{array}{c}\text { Search Terms } \\
\text { Matched With }\end{array}$ & Web Address & $\begin{array}{c}\text { Publications } \\
\text { Found }\end{array}$ \\
\hline $\begin{array}{c}\text { IEEE Xplore Digital } \\
\text { Library }\end{array}$ & $\begin{array}{c}\text { Paper title, keywords, } \\
\text { abstract }\end{array}$ & http://ieeexplore.ieee.org & 117 \\
$\begin{array}{c}\text { ACM Digital } \\
\text { Library }\end{array}$ & $\begin{array}{c}\text { Paper title, keywords, } \\
\text { abstract }\end{array}$ & http://dl.acm.org & 94 \\
El Compendex & $\begin{array}{c}\text { Paper title, keywords, } \\
\text { abstract }\end{array}$ & http://engineeringvillage.com & 487 \\
Elsevier Scopus & $\begin{array}{c}\text { Paper title, keywords, } \\
\text { abstract }\end{array}$ & http://www.scopus.com & 441 \\
\hline
\end{tabular}

\subsubsection{Search Terms}

The search terms adopted in this study, which were used to match paper titles, keywords and abstracts in the performed automatic search, followed the guidelines proposed Kitchenhamet et al. [26]. To define the most relevant search terms for the search, the following strategies were performed:

- Definition of terms from research questions and study topics

- Identification of synonyms, plurals and related terms

- Adoption of the logical operator "OR" to incorporate synonyms

- Concatenate parameters using the logical operator "AND"

- Check the terms in the titles of papers, keywords and abstracts

The resulted search string is composed of synonyms and terms related to "infectious diseases" AND "transmission" AND "prevention" AND “technology", as presented as follows:

("infectious disease" OR "infectious diseases" OR "COVID" OR “COVID-19" OR "SARSCoV-2") AND ("spread" OR "transmission" OR "propagation") AND ("prevention" OR "prevent") AND ("technology" OR "information technology")

The terms related to "COVID-19" were also added since the inclusion of these terms was also of interest to the research.

\subsubsection{Data Sources}

As presented in Table 2, four electronic data sources were selected. Being cited by Kitchenhamet et al. [26] and Chen et al. [27] as relevant sources, the digital libraries were also selected because of the ease of access, the possibility of obtaining full text publications, and the fact that they are used for indexing journals and conference proceedings.

In order to allow a broader scope of the SLR, no limitations for the period of the publications were defined and only papers in English were selected for been considered the standard language of most international journal and conference proceedings.

It should be added that Google Scholar was not included as a data source because of the high possibility of returning inaccurate results and the considerable overlap with ACM and IEEE electronic databases [27]. Table A1 (Appendix A) presents the selected studies retrieved after the execution of the research string, and Table A2 (Appendix A) the mapping regarding the selected digital libraries. 


\subsection{Inclusion and Exclusion Criteria}

In order to allow only relevant studies that met the objectives of the SLR to be returned after the execution of the search string, the inclusion and exclusion criteria presented in Table 3 were adopted.

Table 3. Adopted inclusion and exclusion criteria.

\section{Inclusion Criteria}

I1: Infectious diseases transmission/spread prevention-related works/approaches addressing the use of information technology solutions.

\section{Exclusion Criteria}

E1: Duplicate publications (including different references) E2: Standards, models, industry standards

E3: Editorials, reports, position papers, keynotes, reviews, perspectives, surveys, summaries tutorials, books, courses or workshops, panel discussions

E4: Non-scientific publications

E5: Publications not related to infectious diseases transmission/spread prevention in humans E6: Publications that do not cover "respiratory infectious diseases", or whose approaches could not be applied in the primary ways of preventing transmission of these diseases

E7: Publications that do not have sufficient information to solidly answer the research questions E8: Publications that do not meet the inclusion criteria

\subsection{Study Selection and Data Extraction}

Regarding the publication's selection process, three stages were performed. In the first stage, the electronic bases were selected, the research string was executed in each digital library (on 30 June 2021), and the returned publications were compiled resulting in 1139 papers. Figure 3 presents the steps of the performed study selection and data extraction.

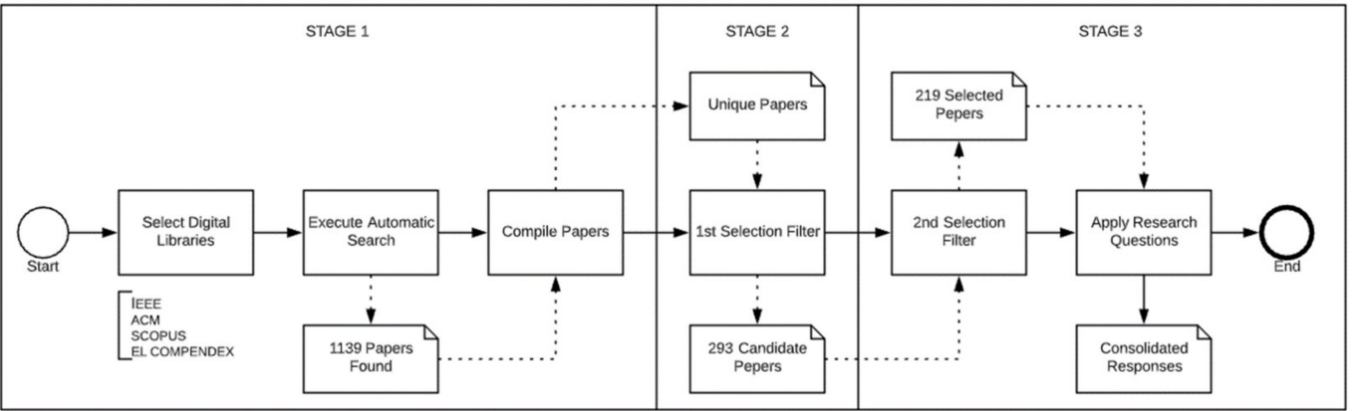

Figure 3. Publication's selection process stages.

In the second stage of the publication's selection process, duplicate papers were discarded, and the first filter was performed, where title, keywords and abstract were read and inclusion and exclusion criteria were applied, resulting in 293 candidate publications.

In the third stage, a second filter was performed where, after all papers were downloaded, a full-text reading of each article was performed applying the inclusion and exclusion criteria, which resulted in 219 papers. Finally, the proposed research questions were applied in all studies where data extraction and answers recording were performed based on the terms presented in Table 4 (results and discussions are presented in Section 4). 
Table 4. Summary of items extracted from each study including research questions and quality criteria.

\begin{tabular}{cccc}
\hline Objective & Item & Objective & Item \\
\hline & Title & RQ5 & Context \\
General & Author(s) & Q1 & Objective of the Study \\
Data & Publication Year & Q2 & Description of the Context \\
& Venue & Q3 & Description of the Research Project \\
RQ1 & Paper Summary & Q4 & Analysis of the Data \\
RQ2 & Approach & Q5 & Conclusions Presentation \\
RQ3 & Application Domain & Q6 & Critical Analysis Description \\
RQ4 & Levted Support Mechanisms & Q7 & Description of Limitations and Bias \\
\hline
\end{tabular}

Table 4 presents the items adopted in the study in order to document the work, meet the research questions and evaluate the quality of the studies. The adopted quality criteria (Q1 to Q7) are described in Section 4.2 and the evidence levels, adopted in order to evaluate the maturity of the techniques described in the selected publications, are listed in Table 5.

Table 5. Levels of Evidence.

\begin{tabular}{|c|c|c|}
\hline Level & Classification & Description \\
\hline 0 & No evidence & $\begin{array}{c}\text { No evidence was presented regarding evaluation } \\
\text { or validation }\end{array}$ \\
\hline 1 & Example or demonstration & $\begin{array}{l}\text { Application description is provided with an } \\
\text { example to aid its description }\end{array}$ \\
\hline 2 & Specialists Notes & $\begin{array}{c}\text { Qualitative or textual assessments are provided. } \\
\text { Example: advantages and disadvantages } \\
\text { contrasts/comparation }\end{array}$ \\
\hline 3 & Experiment in laboratory & $\begin{array}{l}\text { Results are reached from simulations with } \\
\text { artificial data in real experiments. Evidence } \\
\text { collection is performed formally or informally. }\end{array}$ \\
\hline 4 & Empirical Investigation & $\begin{array}{c}\text { Real context investigation of the behavior of the } \\
\text { proposed approach }\end{array}$ \\
\hline 5 & Strict analysis & $\begin{array}{l}\text { Evaluation/validation of the study is performed } \\
\text { using a formal methodology. Example: questions } \\
\text { and variables definition for analysis after the } \\
\text { application of the approach }\end{array}$ \\
\hline
\end{tabular}

Based on the work presented by Chen et al. [28], Table 5 presents the classification items in which the selected publications were validated or evaluated in order to identify the level of evidence of the solutions described.

During the execution of the publication's selection process, the selected studies were presented to another two research studies where, after selection agreement, the publications were classified and categorized (divergences cases in paper selection and/or classification were solved after discussions in order to ensure the inclusion of relevant papers in this study).

\section{Results and Discussions}

In this section, results and discussions regarding the synthesis and analysis of the data extracted from the selected studies to answer the research questions are presented (including demographic data information).

\subsection{Demographic Data}

In order to provide an overview of the studies regarding publication venues, citation count, distribution by year of publication and countries, this section presents the demo- 
graphic information on the selected studies. All included publications are listed in Table A1 (Appendix A).

\section{Publication Venues and Citation Count}

Information regarding publication venues and citations may be potentially useful for researchers interested in conducting research on a relevant topic, as well as partially show the impact of a study, the quality or the maturity of the proposed techniques. This is why it is also important to provide information on the distribution of the selected works on publication venues (as presented in Table A3-Appendix A), as well as an overview of the citation count.

Table A4 (Appendix A) presents an overview of the citation count of the selected publications sorted in descending order (information obtained from Google Scholar on 1 August 2021).

From the descending ordered list in Table A4, it is possible to identify the publications which were most cited where, comparing the 10 most cited studies with the application domain categories as presented in Section 4.3.1, it is possible to identify that six publications (S5, S101, S102, S116, S125, and S132) adopted approaches focusing on pandemic planning application domain (CD4). Tracking, surveillance and Contact tracing (CD6) application domain contained three studies (S114, S208, and S212), and Healthcare and Clinical management (CD1) one study (S104).

Regarding adopted support mechanisms, analyzing the table mapping presented in Section 4.3.2, from the 10 most cited studies, seven publications (S5, S101, S102, S104, S116, S125, and S132) adopted data and mathematical application related solutions, two studies (S114 and S212) adopted internet of things and hardware, and three studies adopted Software/Systems/Apps/Programing languages as support mechanisms (some studies used more than one category of support mechanism).

In Figure 4, the number of selected papers published per year is presented where, from 2020 onwards, a considerable increase in studies can be observed which, as mentioned before, is the period that the COVID-19 pandemic began. In other words, based on these data, it is possible to note that only after a global epidemic crisis emerged that the number of studies focused on the application of technology in primary ways of preventing the transmission of respiratory infectious diseases increased.

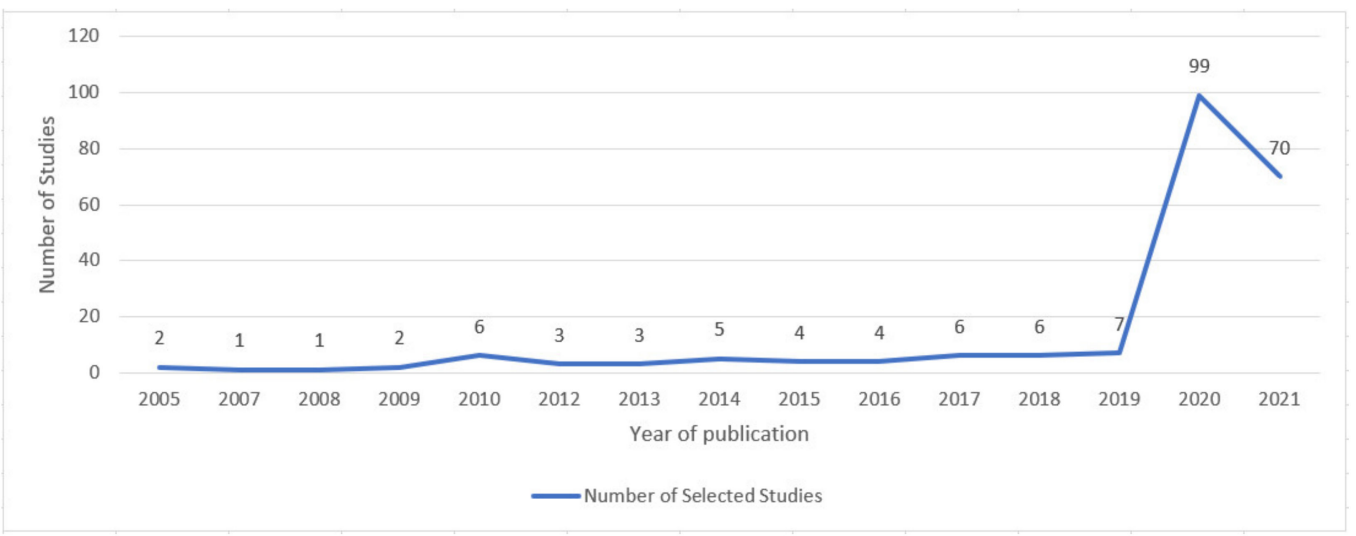

Figure 4. Number of selected papers published per year.

Table A5 (Appendix A) presents the distribution of the papers regarding the domain application categories (see Section 4.3.1) and the authors' institution country. China, United States and India were the countries that presented the largest number of papers (48, 38 and 31 , respectively), representing $53.42 \%$ of the publications selected in this study. 


\subsection{Study Quality Assessment}

To perform the study quality assessment, the 219 studies were evaluated by the authors adopting the set of questions listed in Table 6, which were adopted and adjusted from the work presented by Chen et al. [28] and Dyba et al. [29]. Unlike the quality study proposed by the authors, the questions were not used to select the studies, but to validate the results.

Table 6. Quality assessment questions.

\begin{tabular}{|c|c|c|c|c|}
\hline ID & Quality Assessment Question & Yes & Partially & No \\
\hline Q1 & Are the study objectives and goals clearly specified? & $\begin{array}{c}218 \\
(99.5 \%)\end{array}$ & $\begin{array}{c}1 \\
(0.5 \%)\end{array}$ & $\begin{array}{c}0 \\
(0.0 \%)\end{array}$ \\
\hline Q2 & Is the study context clearly defined? & $\begin{array}{c}113 \\
(51.6 \%)\end{array}$ & $\begin{array}{c}89 \\
(40.6 \%)\end{array}$ & $\begin{array}{c}17 \\
(7.8 \%)\end{array}$ \\
\hline Q3 & $\begin{array}{l}\text { Does the research design support the } \\
\text { objectives/goals of the study? }\end{array}$ & $\begin{array}{c}135 \\
(61.6 \%)\end{array}$ & $\begin{array}{c}71 \\
(32.4 \%)\end{array}$ & $\begin{array}{c}13 \\
(5.9 \%)\end{array}$ \\
\hline Q4 & $\begin{array}{l}\text { Does the study have an adequate description of the } \\
\text { analysis of the data? }\end{array}$ & $\begin{array}{c}96 \\
(43.8 \%)\end{array}$ & $\begin{array}{c}67 \\
(30.6 \%)\end{array}$ & $\begin{array}{c}56 \\
(25.6 \%)\end{array}$ \\
\hline Q5 & $\begin{array}{l}\text { Does the study present a clear statement of the } \\
\text { findings and provide enough data to support them? }\end{array}$ & $\begin{array}{c}79 \\
(36.1 \%)\end{array}$ & $\begin{array}{c}81 \\
(37.0 \%)\end{array}$ & $\begin{array}{c}59 \\
(26.9 \%)\end{array}$ \\
\hline Q6 & $\begin{array}{l}\text { Do researchers critically examine potential bias } \\
\text { and/or influence in the study? }\end{array}$ & $\begin{array}{c}3 \\
(1.4 \%)\end{array}$ & $\begin{array}{c}33 \\
(15.1 \%)\end{array}$ & $\begin{array}{c}183 \\
(83.6 \%)\end{array}$ \\
\hline Q7 & Study limitations are discussed explicitly? & $\begin{array}{c}51 \\
(23.3 \%)\end{array}$ & $\begin{array}{c}66 \\
(30.1 \%)\end{array}$ & $\begin{array}{c}102 \\
(46.6 \%)\end{array}$ \\
\hline
\end{tabular}

During the analysis of the studies (see Section 3.4), each of the questions was answered according to a ratio scale ("Yes," "No" and "Partially"), in order to obtain information about the credibility of the results. As mentioned by Kitchenhamet et al. [26] and Chen et al. [28], the result of quality assessment may also reveal potential limitations of current research and guide future field studies.

As presented in Table 6, the answers regarding the objectives and goals of the studies (Q1) were all positive and, regarding the context definition (Q2), more than $92 \%$ of the studies defined them clearly.

Information regarding the nature and type of the organization, adopted software, team experience and research design to achieve the objectives (Q3) was provided in almost $94 \%$ of the studies, and about $75 \%$ presented an adequate description of the data analysis (Q4) as well as presented a clear statement of the findings (Q5).

However, the greatest concern was about the examination of bias or influence in the study (Q6), where about 83\% did not provide enough (or any) information, as well as in discussions about the study limitations (Q7), where $46.6 \%$ of the papers did not present discussions.

\subsection{Question Analysis}

In the following sub-sections, the analysis and discussions of the research questions will be presented.

\subsubsection{Available Approaches (RQ1) and Application Domains (RQ2)}

During the studies analysis and information extraction phase, the proposed approaches were identified (descriptions presented in Table A1), and the application domains were recognized and grouped into six main categories. Table 7 presents the proposed application domain categories (the number of studies for each category is presented in parentheses after the category name). 
Table 7. Application Domain Categories.

\begin{tabular}{|c|c|}
\hline Category & Studies \\
\hline $\begin{array}{l}\text { CD1: Healthcare and Clinical } \\
\text { management (59) }\end{array}$ & $\begin{array}{l}\text { S4, S11, S14, S21, S24, S25, S27, S31, S37, S38, S39, S40, S56, S57, } \\
\text { S58, S59, S60, S61, S64, S70, S77, S80, S88, S89, S92, S93, S95, } \\
\text { S103, S104, S112, S123, S126, S127, S133, S137, S139, S140, S141, } \\
\text { S150, S151, S157, S158, S160, S168, S171, S181, S182, S183, S187, } \\
\text { S191, S192, S197, S202, S203, S205, S206, S207, S218, S219 }\end{array}$ \\
\hline $\begin{array}{l}\text { CD2: Infection } \\
\text { Testing/Screening (14) }\end{array}$ & $\begin{array}{l}\text { S26, S35, S65, S82, S118, S122, S128, S148, S159, S163, S177, } \\
\text { S185, S193, S198 }\end{array}$ \\
\hline CD3: Mask Detection (16) & $\begin{array}{c}\text { S6, S8, S47, S63, S74, S75, S76, S106, S107, S108, S121, S142, } \\
\text { S143, S144, S152, S178 }\end{array}$ \\
\hline $\begin{array}{l}\text { CD4: Pandemic Planning } \\
\text { (75) }\end{array}$ & $\begin{array}{c}\text { S1, S2, S3, S5, S7, S15, S17, S23, S28, S29, S32, S36, S41, S43, S44, } \\
\text { S45, S46, S48, S51, S53, S54, S55, S62, S66, S68, S71, S78, S81, } \\
\text { S83, S85, S91, S96, S97, S98, S99, S100, S101, S102, S105, S111, } \\
\text { S113, S116, S117, S120, S124, S125, S129, S130, S132, S138, S145, } \\
\text { S146, S147, S153, S155, S156, S161, S164, S165, S169, S170, S173, } \\
\text { S180, S186, S188, S189, S190, S199, S200, S201, S204, S209, S211, } \\
\text { S215, S216 }\end{array}$ \\
\hline $\begin{array}{l}\text { CD5: Quaran- } \\
\text { tine/isolation/containment/ } \\
\text { social distancing }(24)\end{array}$ & $\begin{array}{l}\text { S10, S16, S19, S22, S30, S50, S52, S69, S79, S84, S90, S109, S110, } \\
\text { S119, S131, S135, S167, S172, S174, S179, S184, S194, S195, S213 }\end{array}$ \\
\hline $\begin{array}{l}\text { CD6: Tracking, surveillance, } \\
\text { and Contact tracing (31) }\end{array}$ & $\begin{array}{c}\text { S9, S12, S13, S18, S20, S33, S34, S42, S49, S67, S72, S73, S86, S87, } \\
\text { S94, S114, S115, S134, S136, S149, S154, S162, S166, S175, S176, } \\
\text { S196, S208, S210, S212, S214, S217 }\end{array}$ \\
\hline
\end{tabular}

The categories descriptions are presented below:

- Healthcare and clinical management (CD1): Category that covers approaches that seek to adopt technological solutions focusing on healthcare, case investigation, medical supplies, among others like the ones that seek to diagnose infected individuals, monitor clinical status, predict clinical outcomes, and provide capacity for telemedicine services, virtual care, and hygiene surveillance.

- Infection testing/screening (CD2): A category that covers approaches focusing on screening/testing individuals for diseases, either assessing for signs of disease in an apparently asymptomatic population, for example, or adopting technology with medical procedures to confirm the diagnosis in individuals.

- Mask detection (CD3): Covers approaches that adopt information technology solutions aiming to detect people who are (or are not) using the protective mask.

- Pandemic Planning (CD4): Covers approaches that aim at the identification/obtainment of new information that can be used or contribute to the prevention and/or control of transmission of infectious diseases, including anticipation of behaviors, transmissions, new outbreaks of epidemics, among others.

- Quarantine/isolation/containment/social distancing (CD5): Category of approaches involving the application of technology in order to restrict the spread of infection through the contribution to social distancing, containment or isolation of indeciduous; for example, monitoring quarantine patients, restricting social contact using global positioning systems or mobile phone applications, among others.

- Tracking, surveillance, and Contact tracing (CD6): Include approaches that aim at the identification, tracking or tracing of individuals who might have come into contact with an infected person in order to tracks viral spread; for example, monitors the spread of infection across locations, or to prevent onward transmission by alerting those who came in contact with the positive case. 
Of the selected studies, we can highlight that most of the works (about $61.19 \%$ ) focused on pandemic planning (CD4) and healthcare and clinical management (CD1) related application domains, obtaining a percentage of about $34.25 \%$ for the CD4 category, and $26.94 \%$ for the CD1 category.

Regarding tracking, surveillance, and contact tracing (CD6)-related approaches, 31 studies $(14.15 \%)$ were found and, with respect to Quarantine/isolation/containment/social distancing (CD5) application domain, 24 studies (10.96\%) were identified.

Mask detection (CD3) and infection testing/screening (CD2)-related application domains were the ones with the fewest studies with only $7.31 \%$ and $6.39 \%$, respectively.

Figure 5 presents the quantitative distribution of studies by application domain category regarding the period of publication, where it is possible to observe that studies related to the categories CD3 and CD5 only appeared after 2020 and it was only in 2019 that studies related to the CD2 category emerged in publications.

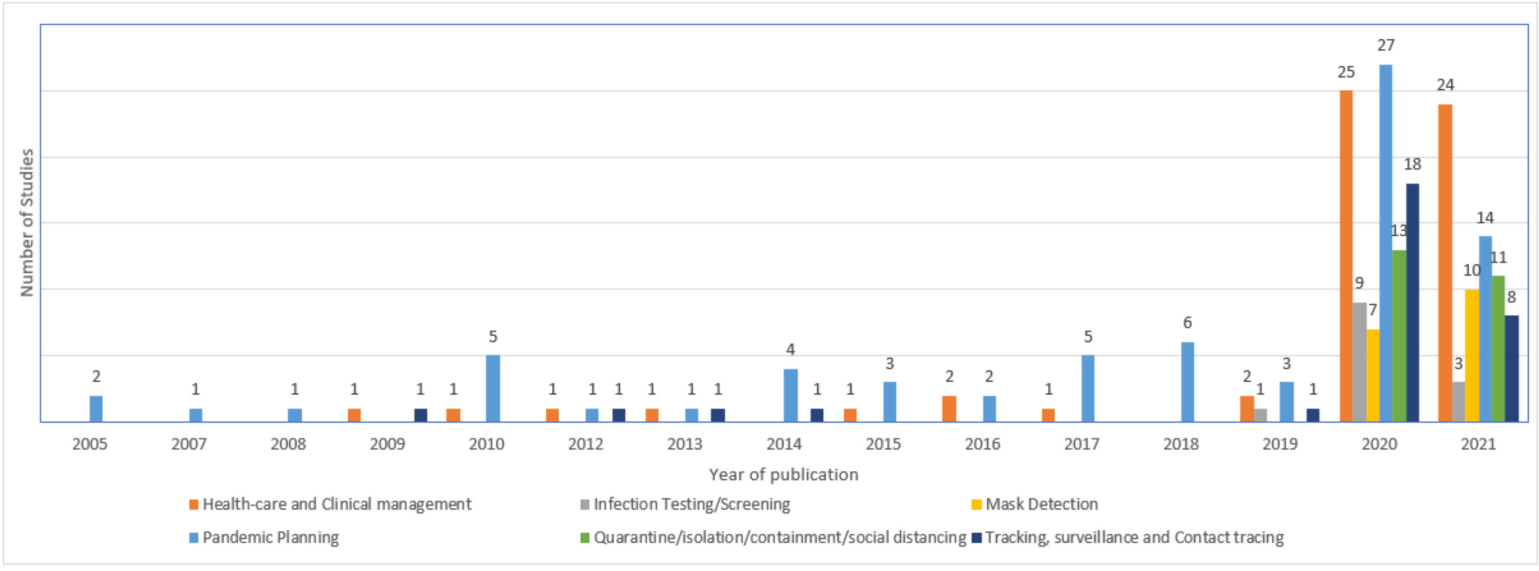

Figure 5. Distribution of studies by application domain and year of publication.

It should be added that the studies were categorized regarding application domains that received greater prominence; although, in some cases, some fell into more than one category. Studies with more than one application domain were: S10 and S693 (CD3 and CD5); S53 and S79 (CD5 and CD6); S82 and S185 (CD2 and CD3); S109 (CD2 and CD5); and S121 (CD1 and CD3).

\subsubsection{Adopted Support Mechanisms (RQ3)}

After the identification of application domain categories of the selected studies, another important step would be the identification and categorization of the adopted/proposed support mechanisms. The mapping of the identified mechanisms according to the proposed categories (and sub-categories) is presented in Table 8 (the number of studies for each support mechanism is presented in parentheses).

Finishing the studies analysis and extraction of the support mechanisms information, four general categories (and nine sub-categories) were identified and adopted in order to group the selected studies. It should be added that it is common that some studies adopted more than one support mechanism, so they were included in more than one category. 
Table 8. Support Mechanisms.

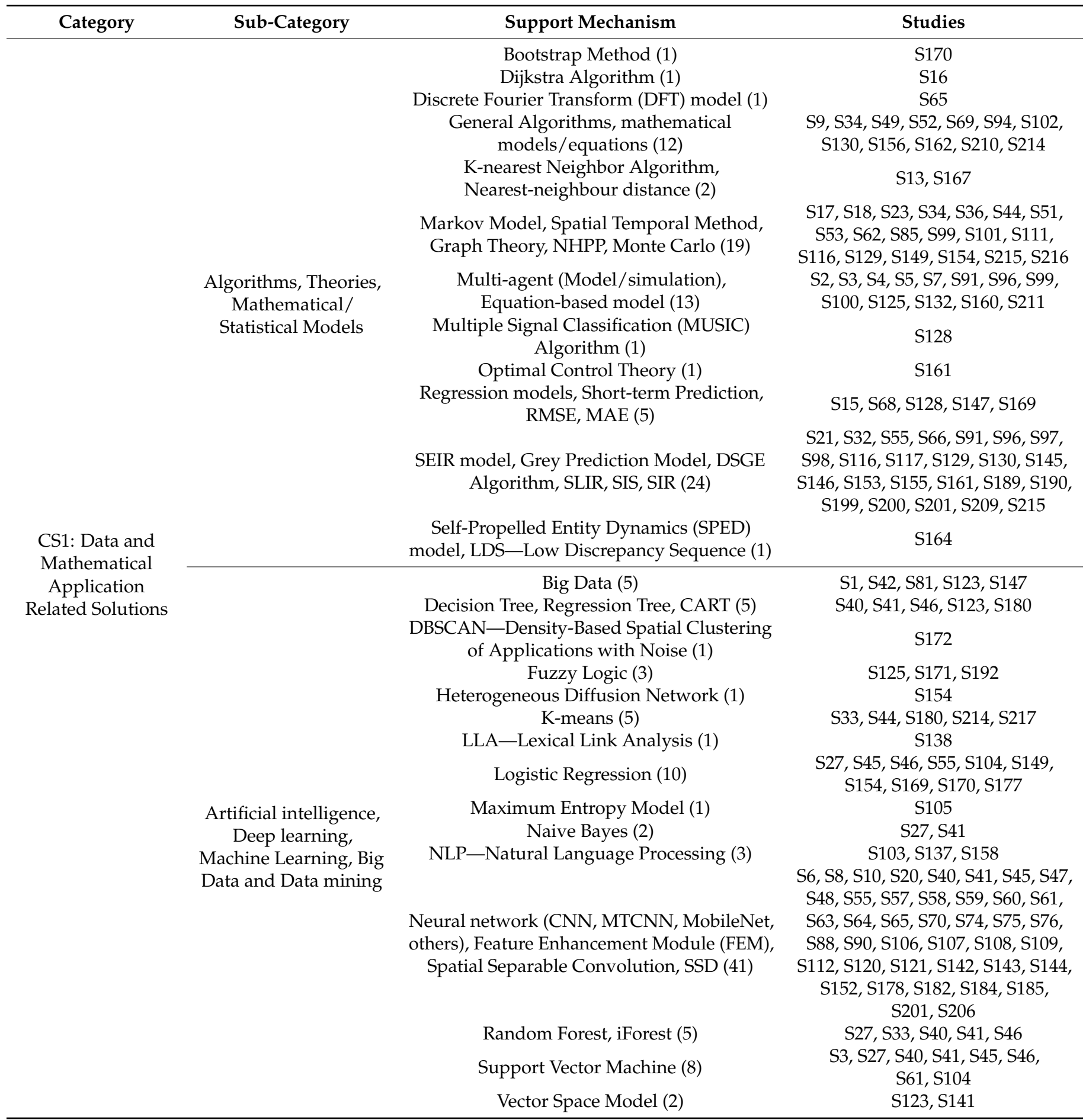


Table 8. Cont.

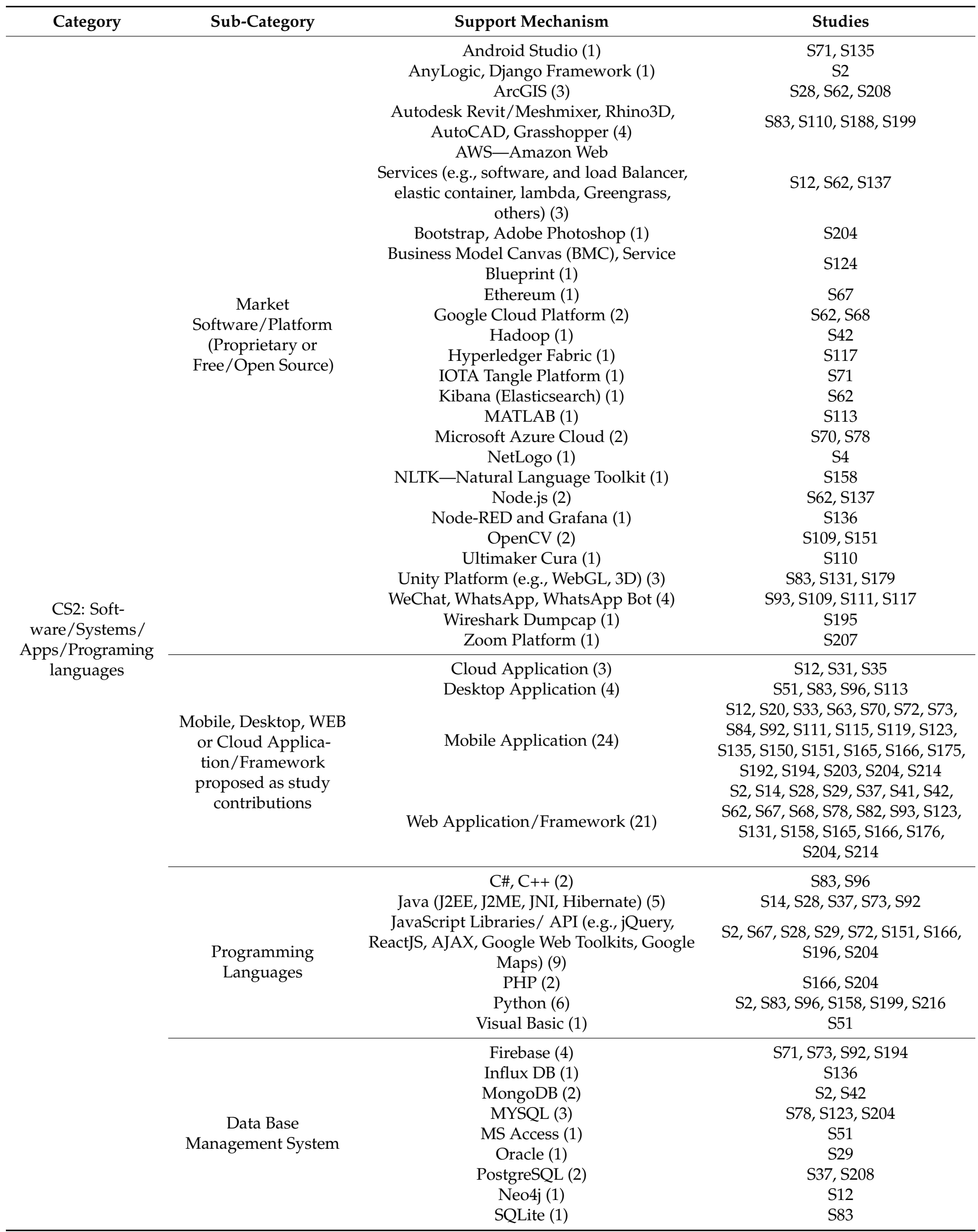


Table 8. Cont.

\begin{tabular}{|c|c|c|c|}
\hline Category & Sub-Category & Support Mechanism & Studies \\
\hline \multirow{11}{*}{$\begin{array}{l}\text { CS3: Internet of } \\
\text { Things and } \\
\text { Hardware }\end{array}$} & $* 1$ & $\begin{array}{l}\text { Wearable devices (e.g.,smartwatches, } \\
\text { smartphones, smartbelt, and others) (17) }\end{array}$ & $\begin{array}{l}\text { S19, S27, S40, S54, S56, S69, S70, } \\
\text { S79, S111, S115, S139, S157, S163, } \\
\text { S175, S181, S195, S213 }\end{array}$ \\
\hline & & $\begin{array}{l}\text { Cameras-photo and video } \\
\text { (Fixed and mobile) (11) }\end{array}$ & $\begin{array}{c}\text { S30, S74, S82, S106, S109, S118, } \\
\text { S121, S122, S128, S193, S194 } \\
\text { S11. S16, S21 S30, S38, S47. S50 }\end{array}$ \\
\hline & $\begin{array}{l}\text { Sensors (mobile or } \\
\text { fixed), Cameras, RFID }\end{array}$ & $\begin{array}{l}\text { Environment Sensors (e.g., Passive Infrared } \\
\text { (PIR) Sensor, and others) (26) }\end{array}$ & $\begin{array}{l}\text { S54, S74, S77, S82, S89, S109, S114, } \\
\text { S121, S122, S126, S127, S135, S136, } \\
\text { S172, S177, S185, S191, S192, S193 }\end{array}$ \\
\hline & $\begin{array}{l}\text { (Radio Frequency } \\
\text { Identification) }\end{array}$ & $\begin{array}{c}\text { RFID (Radio Frequency Identification) } \\
\text { devices (9) }\end{array}$ & $\begin{array}{c}\text { S13, S27, S30, S35, S50, S182, S185, } \\
\text { S192, S196 }\end{array}$ \\
\hline & & $\begin{array}{l}\text { Wearable and/or mobile body sensors (e.g., } \\
\text { temperature, cough, oxygen, pressure, heart } \\
\text { rate measurement) (14) }\end{array}$ & $\begin{array}{c}\text { S21, S25, S26, S27, S31, S35, S44, } \\
\text { S69, S86, S87, S118, S157, } \\
\text { S159, S181 }\end{array}$ \\
\hline & \multirow{5}{*}{$\begin{array}{l}\text { Others (e.g., Printers, } \\
\text { Spray, Chips, } \\
\text { GPS/GSM/Bluetooth } \\
\text { devices, WIFI routers, } \\
\text { UV tech, WBAN, } \\
\text { and others) }\end{array}$} & $\begin{array}{l}\text { Bluetooth/WIFI/GPS/Wireless devices (e.g., } \\
\text { module, routers, access point, receivers, SMS } \\
\text { gateways, GPS chips, and others) (21) }\end{array}$ & $\begin{array}{c}\text { S9, S18, S26, S31, S44, S50, S84, } \\
\text { S86, S123, S124, S134, S136, S142, } \\
\text { S148, S172, S175, S194, S196, S207, } \\
\text { S212, S219 }\end{array}$ \\
\hline & & $\begin{array}{c}\text { Desktops, Laptops, and computer accessories } \\
\text { (e.g., memory cards, processors, and other } \\
\text { boards) (21) }\end{array}$ & $\begin{array}{c}\text { S25, S31, S39, S47, S74, S86, S109, } \\
\text { S114, S121, S123, S134, S136, S137, } \\
\text { S139, S185, S191, S192, S197, S198, } \\
\text { S207, S219 }\end{array}$ \\
\hline & & Printer and scan devices ( 3 ) & S110, S174, S218 \\
\hline & & Spray/Dispenser devices (6) & S11, S82, S168, S191, S205, S219 \\
\hline & & $\begin{array}{l}\text { UV technology (e.g., UVC, UV Chip, UV Led, } \\
\text { UV Light, UV ray) (7) }\end{array}$ & S11, S24, S38, S95, S127, S133, S148 \\
\hline & Robot/Drones & $\begin{array}{l}\text { Robot/Drones/Unmanned Aerial Vehicles } \\
\qquad(\text { UAV) (14) }\end{array}$ & $\begin{array}{c}\text { S18, S22, S43, S80, S90, S127, S140, } \\
\text { S167, S173, S183, S187, S198, } \\
\text { S205, S218 }\end{array}$ \\
\hline CS4: Blockchain & $* 1$ & Blockchain (7) & $\begin{array}{c}\text { S43, S67, S71, S117, S162, } \\
\text { S173, S186 }\end{array}$ \\
\hline
\end{tabular}

*1 Fields with “*” have no value.

Regarding studies that adopted algorithms, theories, mathematical/statistical models, a greater tendency was observed in the application of SEIR model, Gray Prediction Model, DSGE Algorithm, SLIR, SIS, SIR (24 studies), followed by Markov Model, Spatial Temporal Method, Graph Theory, NHPP, and Monte Carlo (19 studies). This grouping of studies was due to the fact that these studies used most of these mathematical models in their approaches or evaluations.

Regarding studies that applied artificial intelligence, deep learning, machine learning, big data and data mining, the greatest trend of the approaches applications was in neural network, feature enhancement module (FEM), spatial separable convolution, and SSD with a total of 41 studies.

Most of the studies that adopted mathematical models or machine learning focused on prediction for decision-making (or simulations) regarding present or future actions in pandemics, such as vaccination, social isolation, disease transmission and control, among others (see Table A1 for descriptions of the proposed approaches). In addition to assistance in increasing the capacity and accuracy of identification of infectious diseases cases and their expansion, artificial intelligence, machine learning, and big data also received a lot of attention from studies that focused on screening, contact tracing, and diagnosis of infectious diseases.

Regarding support mechanisms related to software/systems/apps/programing languages (CS2) category (with 66 papers), studies were included that used existing market 
paid/free software or developed software/mobile apps as research contributions (programming languages and database management systems were also included).

With regard to studies that proposed Mobile, Desktop, WEB or Cloud applications or frameworks (see Table A1 for details of the approaches), for the case of Web and Cloud applications, there was a trend towards solutions focused on support for decision making, disease surveillance, and issuing alerts of critical areas with higher incidences of disease cases.

For Mobile applications, there was a greater tendence in contact tracing, social distancing, and body-symptoms detection/analysis. Regarding Desktop application, the proposed solutions focused on the containment of infectious disease outbreaks using geographical information with mathematical methods/models' application.

Although many studies have proposed software or mobile apps as contributions in their approaches, there was a lack of detailed information regarding the adopted programming languages and database management systems (see Table 8). These situations usually occurred more in studies that also proposed the application of algorithms, theories, mathematical/statistical models and/or artificial intelligence, deep learning, machine learning, big data and data mining (CS2).

Regarding mobile applications, despite the lack of detail in the adopted programming languages or database management systems, most studies reported that the applications were developed with versions available for smartphones with Android and IoS (Apple), except for studies S72, S73, S92, S150, S151, and S194.

Regarding the adoption of internet of things and hardware (category CS3), most studies adopted sensors like environment (26 studies) and body (14 studies) sensors. In the case of environment sensors, there was a greater trend in the adoption for screening potential infectious diseases carriers from distance (e.g., temperature measurement/scanning), local position or movement measurement, automation of devices for hygiene (e.g., hand hygiene), and monitoring occupancy of places (e.g., monitoring elevator occupancy using a Passive Infrared (PIR) sensor).

Regarding studies that adopted wearable and/or mobile body sensors (14 studies), there was a greater tendence towards the verification of a Pearson's heart rate, temperature, blood oxygen level and blood pressure. Video and photo cameras (11 studies) were used in devices such as smartphones, tablets, smart gates, cabins, doors, among other places, in order to collect video and/or image for purposes such as detecting use of masks, population monitoring, among others.

To enable communication between various IoT devices (e.g., mobile devices communicating among each other or with a centralized access point or server), devices with bluetooth/wifi/wireless technology ( 21 studies) or with RFID technology (9 studies) were adopted.

Desktops, laptops and computer accessories such as memory cards, processors, and other boards (e.g., Raspberry pi, Arduino Uno, BeagleBoard-Xm, AT89S52 microcontroller, and others) have been adopted in 21 studies as accessories for the proposed approaches (see Table A1 for descriptions of the proposed approaches) or to be adopted with others support mechanisms, as well as printers and scan devices (3 studies). Manufacturer names and device versions were not considered for the mapping of the identified hardware.

Along with sensors and cameras, drones and/or unmanned aerial vehicles were adopted in 14 studies, with a greater tendency in population monitoring for purposes such as information collection of social distancing and contact tracing.

Regarding surface disinfection in private or public spaces (including hand hygiene), automatic sprays and robots were adopted (see Table A1 for descriptions of the proposed approaches) and, with regard to studies that adopted Blockchain (7 studies), there was also a greater concern with the security in the sending and storage of the user data.

In Figure 6, the quantitative distribution of the selected papers by sub-categories of support mechanisms is presented. 


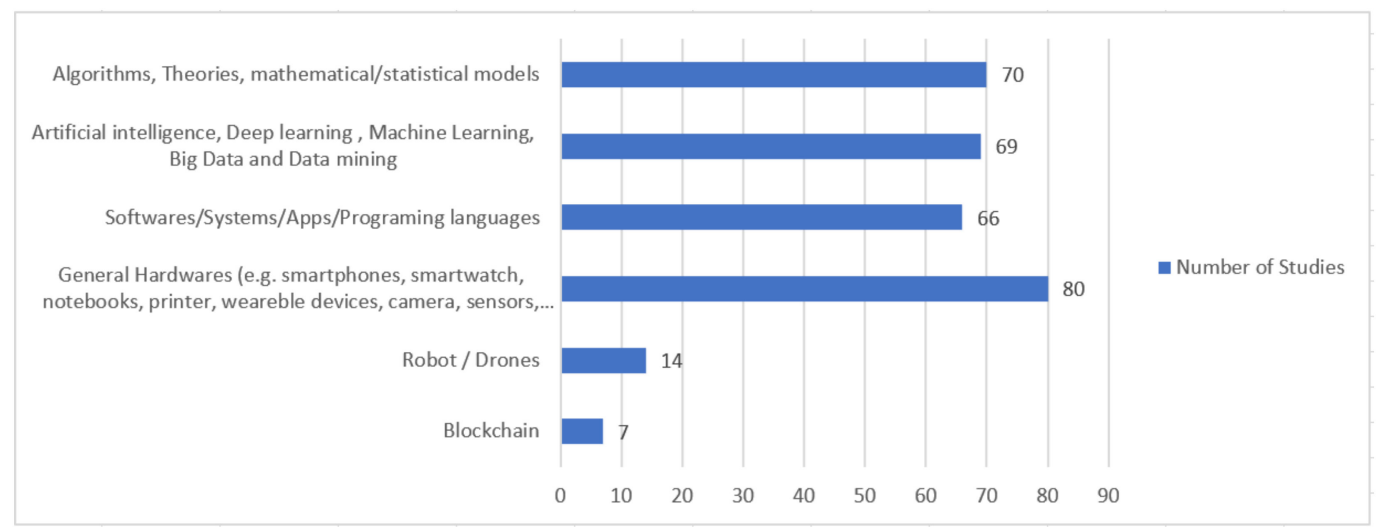

Figure 6. Quantitative distribution of the studies by support mechanisms.

Of the selected studies, there was a greater tendency (139 studies) to adopt data and mathematical application related solutions (CS1), where most studies focused on the application of algorithms mathematical/statistical models (70 studies), and artificial intelligence, deep learning, machine learning, big data and data mining (69 studies).

The second category that showed greater adherence (94 studies) regarding the use/ proposal of support mechanisms was related to the general use of internet of things and hardware (CS3) such as, for example, drones, robots, smartphones, smartwatch, wearable devices, camera, sensors, among others.

\subsubsection{Available Evidence (RQ4) and Context Application (RQ5)}

In order to obtain information regarding available evidence (RQ4) and context application (RQ5), data extraction was performed based on the items presented in Table 4, also aiming to investigate the maturity of the selected studies.

In Table 9, the distribution of the studies regarding the evidence levels (as described in Table 5) and context application (academic or industrial) is presented (the number of studies for each context/evidence level is presented in parentheses).

Table 9. Study distribution regarding evidence level and context.

\begin{tabular}{|c|c|c|}
\hline \multirow{2}{*}{ Evidence Level } & \multicolumn{2}{|c|}{ Context } \\
\hline & Academic (121) & Industrial (98) \\
\hline $\begin{array}{l}\text { 0: No evidence } \\
\quad(13) \\
\text { 1: Example or } \\
\text { demonstration } \\
\quad(36)\end{array}$ & $\begin{array}{l}\text { S3, S11, S20, S25, S53, S56, S70, } \\
\text { S124, S126, S141, S150, S177, S181, } \\
\text { S1, S5, S9, S12, S26, S30, S31, S33, } \\
\text { S36, S50, S67, S69, S79, S81, S82, } \\
\text { S84, S87, S101, S107, S127, S133, } \\
\text { S134, S140, S146, S163, S165, S166, } \\
\text { S175, S179, S185, S191, S193, S197, } \\
\text { S208, S213, S214, }\end{array}$ & $* 1$ \\
\hline 2: Specialists Notes (7) & $\begin{array}{c}\text { S14, S47, S71, S72, S86, S174, S194, } \\
\text { S2, S7, S8, S10, S13, S16, S18, S34, } \\
\text { S40, S43, S44, S49, S51, S52, S54, } \\
\text { S59, S62, S64, S66, S75, S80, S89, }\end{array}$ & $\begin{array}{c}* 1 \\
\text { S4, S6, S17, S23, S37, S38, S39, } \\
\text { S41, S60, S61, S65, S68, S74, } \\
\text { S76, S77, S92, S95, S106, S108, }\end{array}$ \\
\hline $\begin{array}{l}\text { 3: Experiment in } \\
\text { laboratory } \\
(117)\end{array}$ & $\begin{array}{l}\text { S90, S91, S94, S96, S98, S99, S100, } \\
\text { S102, S103, S104, S105, S109, S112, } \\
\text { S115, S119, S121, S122, S129, S132, } \\
\text { S142, S145, S151, S153, S156, S158, } \\
\text { S159, S161, S162, S164, S171, S172, } \\
\text { S173, S180, S182, S186, S190, S200, } \\
\text { S206, S209, S210, S211, S215, S219 }\end{array}$ & $\begin{array}{l}\text { S110, S111, S113, S116, S117, } \\
\text { S118, S120, S123, S125, S128, } \\
\text { S136, S138, S143, S147, S148, } \\
\text { S152, S155, S160, S167, S170, } \\
\text { S183, S184, S187, S188, S189, } \\
\text { S195, S196, S198, S199, S202, } \\
\text { S204, S216, S218 }\end{array}$ \\
\hline
\end{tabular}


Table 9. Cont.

\begin{tabular}{|c|c|c|}
\hline \multirow{2}{*}{ Evidence Level } & \multicolumn{2}{|c|}{ Context } \\
\hline & Academic (121) & Industrial (98) \\
\hline $\begin{array}{l}\text { 4: Empirical Investigation } \\
\qquad(24)\end{array}$ & $* 1$ & $\begin{array}{l}\text { S19, S22, S27, S28, S29, S32, } \\
\text { S46, S55, S73, S83, S85, S88, } \\
\text { S93, S130, S131, S135, S139, } \\
\text { S154, S169, S176, S203, S205, } \\
\text { S207, S212, }\end{array}$ \\
\hline 5: Strict analysis (22) & $* 1$ & $\begin{array}{l}\text { S15, S21, S24, S35, S42, S45, } \\
\text { S48, S57, S58, S63, S78, S97, } \\
\text { S114, S137, S144, S149, S157, } \\
\text { S168, S178, S192, S201, S217 }\end{array}$ \\
\hline
\end{tabular}

*1 Fields with "*" have no value.

From the distribution presented in Table 9, only 13 studies did not present any evidence and, regarding demonstrations or examples, 36 studies presented application descriptions in the academic context.

Most studies carried out experiments both in academic contexts (65 studies) with fictitious data, and in industrial contexts (52 studies) with data obtained from real case scenarios. Expert observations such as textual, qualitative or opinion evaluations were provided in eight studies limited to the academic context.

Adding the studies carried out in laboratories (117 papers) with the studies that carried out both empirical investigation (46 papers) and strict analysis (22 papers), it can be seen that studies aimed at preventing the transmission of infectious diseases through the use of technology have, for the most part, some evidence with tests (total of 163 papers).

As the studies analyzed in this systematic review focus on the application of technologies in the primary ways of preventing the transmission of respiratory infectious diseases, it is also interesting to identify the context in relation to the diseases. Thus, Table 10 presents the distribution of studies regarding diseases in which the use of technology was proposed to contribute to their prevention (the number of studies for each disease category is presented in parentheses).

Table 10. Papers distribution according to the studied diseases.

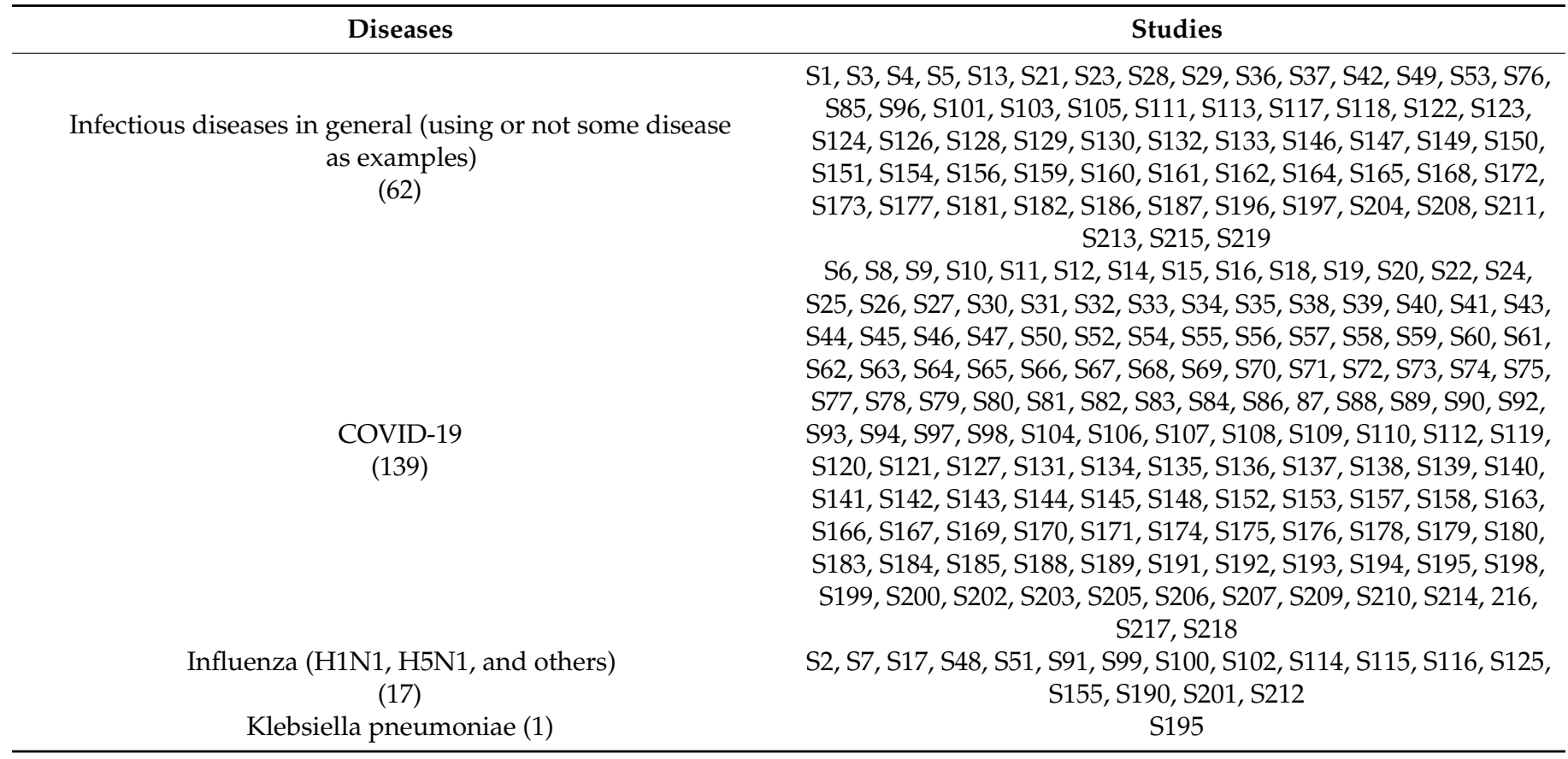


It should be added that the use of the term "Infectious diseases in general" was adopted to group studies that, despite using or not diseases as an example, have their approach generalized to infectious diseases in general, whose transmission can be reduced through primary forms of prevention, such as social distancing, mask usage, isolation and quarantine. Therefore, they were grouped separately from those studies whose approaches were proposed specifically for the diseases listed in Table 10.

As presented in Table 10, it is possible to identify a greater concentration of studies focused on the use of technology in the primary ways of preventing COVID-19 (139 studies), followed by infectious diseases in general (62 studies).

\section{Research Implications and Limitations}

As mentioned earlier, in order to obtain the greatest possible number of relevant studies in the systematic review, a comprehensive search was performed with automatic searches in digital libraries adopting terms related to the subject matter of the search. To contribute to the selection of relevant studies, inclusion and exclusion criteria were applied in two stages.

Regarding possible threats to the validity of this systematic review, we can mention the possibility of bias in the selection of publications and in data extraction where, due to the possibility of subjectivity in decision making, researchers' bias can affect the results of the work.

To contribute to the reduction in bias in the selection of publications, the review protocol was initially developed by a researcher, and validated by two other researchers with extensive knowledge and experience in software engineering and in works related to systematic literature reviews. After completion of the review protocol, it was strictly followed.

The selection process of the studies was then conducted in three stages (see Section 3.4) to reduce the chances of exclusion of relevant studies, and to contribute to bias reduction. The study selection process was conducted by one researcher, and all included and excluded studies were examined by two other researchers (inclusion and exclusion motivations were recorded and disagreements were resolved through discussions).

The option of adopting only automatic searches in digital libraries was also chosen as a way to contribute to the reduction in bias in the search and selection of studies. The terms adopted in the searches were iteratively improved based on the evaluation searches and were carefully tested before the execution of the systematic review.

In order to reduce threats regarding data extraction inaccuracies, a data extraction form was created (as presented in Table 4) to enable a more consistent extraction and analysis of data to answer the proposed research questions of this systematic review.

To contribute to bias reduction, the data extraction procedure was performed by two researchers who executed the data extraction and verification of the selected studies performing a complete reading of the works and answering the research questions and the quality criteria according to Table 4 . After recording and analyzing the extracted information, similar positions and conclusions were unified, and disagreements were resolved through discussions.

After obtaining the results, the third researcher validated them, acting as the final decision-maker for discussions when no agreement was made.

The quality assessment of the papers also contributed to the increase in accuracy and precision of data extraction process, giving more credibility to the fact that extracted data comes from reliable studies.

The major limitations of the studies are the limited number of selected sources (only four digital libraries), and the fact that only automatic searches were performed, where the use of keywords may not cover all studies that use technology in the primary forms of prevention of transmission of infectious diseases. 
This may happen because the searched terms may not be explicit in the title, keywords, or abstracts of the studies, as well as the string search, which may not contain the full set of terms required to obtain all the relevant works available in the digital libraries.

Another limitation that should be added is that, although the guidelines suggested by Kitchenhamet et al. [26] were adopted in this systematic review, instead of having the participation of a group of researchers in the data extraction, only three participated. Although the performance of analysis activity by a single researcher is common in many studies, it can also lead to questions regarding the description or classification of the collected data. To contribute to the reduction in bias in this scenario, three researchers participated in the study.

\section{Conclusions}

In the race against the spread of transmissible infectious diseases, there has been a growing interest in the use of technological solutions in the primary ways of preventing the transmission of these diseases.

Due to the importance of the subject, mainly due to its economic and social impact to society, it is equally important to systematically identify, analyze and document what is being carried out and studied, discovering new directions, as well as having a better understanding of how technologies are being used in this scenario, its main objectives, adopted support mechanisms, level of evidence reported, gaps that need to be deepened in research, as well as to organize the knowledge to support the technological transition.

For this purpose, this work presented the design, execution, and results of a comprehensive systematic literature review of relevant studies on information technology applications in the primary ways of prevention of new infectious diseases transmission.

Based on the findings, it was possible to identify issues relevant to interested researchers and practitioners, as well as contributing to the availability of an evidence-based guide to select appropriate technologies, approaches, solutions, or support mechanisms based on the different needs or scenarios.

From the results presented in this literature review, it was possible to identify six application domain categories of the selected studies in which there was a greater trend in studies related to pandemic planning and, among the support mechanisms adopted, data and mathematical application related solutions received greater attention.

From the mapping of support mechanisms carried out, it was also possible to identify a trend towards the application of artificial intelligence, deep learning, and machine learning technologies in primary ways of preventing transmission of respiratory infectious diseases. Thus, a thorough analysis and comparison of these algorithms (e.g., analysis of the success rate of the algorithms) is proposed as future works.

Regarding quality assessment analysis, most of the studies did not provide enough (or any) information about the examination of bias or influence in the study, as well as in discussions about the study limitations. Regarding available evidence, most of the studies presented some evidence (with tests).

From the findings, a greater tendency of studies focused on the use of technology in the primary ways of preventing COVID-19 was identified, followed by infectious diseases in general.

While it cannot be said that the study is exhaustive, it is believed to be a useful resource for interested researchers and practitioners regarding the use of technological solutions in the primary ways of preventing the transmission of infectious diseases.

For future works, it is recommended to expand the scope of this study with manual searches, including with searches in the references of the selected studies (through snowball techniques). 
Author Contributions: Conceptualization, G.S.L., A.B.A. and P.R.P.; data curation, G.S.L.; formal analysis, G.S.L., A.B.A. and P.R.P.; investigation, G.S.L. and P.R.P.; methodology, G.S.L., A.B.A. and P.R.P.; project administration, G.S.L., A.B.A. and P.R.P.; resources, G.S.L. and P.R.P.; software, G.S.L.; supervision, A.B.A. and P.R.P.; validation, G.S.L., A.B.A. and P.R.P.; visualization, G.S.L., A.B.A. and P.R.P.; writing — original draft, G.S.L. and A.B.A.; writing-review and editing, A.B.A. and P.R.P. All authors have read and agreed to the published version of the manuscript.

Funding: This research received no external funding.

Institutional Review Board Statement: Not applicable.

Informed Consent Statement: Not applicable.

Data Availability Statement: Not applicable.

Conflicts of Interest: The authors declare no conflict of interest.

\section{Appendix A}

See Tables A1-A5.

Table A1. Selected Publications.

\begin{tabular}{|c|c|c|c|c|c|}
\hline ID & Reference & Title & Approach & $\begin{array}{l}\text { Venue } \\
\text { Acronym }\end{array}$ & Year \\
\hline $\mathrm{S} 1$ & [30] & $\begin{array}{l}\text { A big data architecture to a multiple } \\
\text { purpose in healthcare surveillance: the } \\
\text { Brazilian syphilis case }\end{array}$ & $\begin{array}{l}\text { Big data architecture to a multiple } \\
\text { purpose in healthcare surveillance }\end{array}$ & EATIS & 2020 \\
\hline $\mathrm{S} 2$ & [31] & $\begin{array}{l}\text { A computational paradigm for the } \\
\text { simulation of complex epidemic diseases }\end{array}$ & $\begin{array}{l}\text { Paradigm for modeling and } \\
\text { simulation of complex system using } \\
\text { agent-based model }\end{array}$ & SoICT & 2016 \\
\hline S3 & [32] & $\begin{array}{l}\text { A development of an efficient information } \\
\text { collecting and retrieval system using an } \\
\text { Agent Technology for infectious disease }\end{array}$ & $\begin{array}{l}\text { Information retrieval system with } \\
\text { agent technology for the field of } \\
\text { infection disease }\end{array}$ & Healthcom & 2005 \\
\hline $\mathrm{S} 4$ & [33] & $\begin{array}{l}\text { A dynamic patient network model of } \\
\text { hospital-acquired infections }\end{array}$ & $\begin{array}{l}\text { Agent-based model to simulate the } \\
\text { effect of network density and patient } \\
\text { sharing on transmission }\end{array}$ & WSC & 2010 \\
\hline S5 & [34] & $\begin{array}{l}\text { A hybrid epidemic model: combining the } \\
\text { advantages of agent-based and } \\
\text { equation-based approaches }\end{array}$ & $\begin{array}{l}\text { Model and initial examples of a } \\
\text { threshold hybrid model that switches } \\
\text { between agent-based and } \\
\text { equation-based descriptions }\end{array}$ & WSC & 2017 \\
\hline S6 & [35] & $\begin{array}{c}\text { A Mask Detection Method for Shoppers } \\
\text { Under the Threat of COVID-19 } \\
\text { Coronavirus }\end{array}$ & $\begin{array}{l}\text { Single-shot detector (SSD) based } \\
\text { method for face masks detection in } \\
\text { the supermarket }\end{array}$ & CVIDL & 2020 \\
\hline S7 & [36] & $\begin{array}{c}\text { A multi-agent model for adaptive } \\
\text { vaccination during infectious disease } \\
\text { outbreaks }\end{array}$ & $\begin{array}{l}\text { Age-structured multi-agent model to } \\
\text { simulate an epidemic spread }\end{array}$ & ICCTIDE & 2016 \\
\hline S8 & [37] & $\begin{array}{l}\text { A Network for Detecting Facial Features } \\
\text { During the COVID-19 Epidemic }\end{array}$ & $\begin{array}{c}\text { Facial feature detection algorithm } \\
\text { based on Mtcnn + Mobilenet + GDBT }\end{array}$ & CCEAI & 2021 \\
\hline S9 & [38] & $\begin{array}{c}\text { A note on blind contact tracing at scale } \\
\text { with applications to the COVID-19 } \\
\text { pandemic }\end{array}$ & $\begin{array}{l}\text { Cryptographic approach to contact } \\
\text { tracing based on secure two-party } \\
\text { computation }\end{array}$ & ARES & 2020 \\
\hline S10 & [39] & $\begin{array}{l}\text { A Novel COVID Prevention Method Using } \\
\text { Deep Learning }\end{array}$ & $\begin{array}{l}\text { PC vision and MobileNet V2 } \\
\text { architecture adoption in social } \\
\text { distancing and mask detection }\end{array}$ & ICPECTS & 2020 \\
\hline S11 & [40] & $\begin{array}{l}\text { A Novel Method of Mass Disinfection for } \\
\text { the Prevention of COVID-19 }\end{array}$ & $\begin{array}{l}\text { Technology solution that adopts } \\
\text { Ultraviolet-C light exposure along } \\
\text { with disinfectant spray }\end{array}$ & IJCRR & 2021 \\
\hline S12 & [41] & $\begin{array}{c}\text { A Privacy-Preserving Mobile and Fog } \\
\text { Computing Framework to Trace and } \\
\text { Prevent COVID-19 Community } \\
\text { Transmission }\end{array}$ & $\begin{array}{l}\text { E-government Privacy-Preserving } \\
\text { Mobile, and Fog computing } \\
\text { framework to trace infected people }\end{array}$ & $\begin{array}{l}\text { IEEE J Biomed } \\
\text { Health Inform }\end{array}$ & 2020 \\
\hline
\end{tabular}


Table A1. Cont.

\begin{tabular}{|c|c|c|c|c|c|}
\hline ID & Reference & Title & Approach & $\begin{array}{l}\text { Venue } \\
\text { Acronym }\end{array}$ & Year \\
\hline S13 & [42] & $\begin{array}{c}\text { A RFID-Based Infection Prevention and } \\
\text { Control Mechanism in Aged Care Living } \\
\text { Residences }\end{array}$ & $\begin{array}{l}\text { Visual infection control positioning } \\
\text { system for aged care facilities }\end{array}$ & $\begin{array}{l}\text { Mob. Netw. } \\
\text { Appl. }\end{array}$ & 2021 \\
\hline S14 & [43] & $\begin{array}{c}\text { A Service-oriented Framework for } \\
\text { Developing Personalized Patient Care } \\
\text { Plans for COVID-19 }\end{array}$ & $\begin{array}{l}\text { Service oriented framework that } \\
\text { allows for dynamic composition and } \\
\text { management of personalized } \\
\text { patient care }\end{array}$ & DG.O & 2021 \\
\hline S15 & {$[44]$} & $\begin{array}{c}\text { A Short-Term Prediction Model at the Early } \\
\text { Stage of the COVID-19 Pandemic Based on } \\
\text { Multisource Urban Data }\end{array}$ & $\begin{array}{l}\text { Short-term prediction model for } \\
\text { COVID-19 cases }\end{array}$ & TCSS & 2021 \\
\hline S16 & [45] & $\begin{array}{l}\text { A Social IoT-Driven Pedestrian Routing } \\
\text { Approach During Epidemic Time }\end{array}$ & $\begin{array}{l}\text { Pedestrians safely navigation } \\
\text { framework with Social IoT adoption }\end{array}$ & GCAIoT & 2020 \\
\hline S17 & [46] & $\begin{array}{c}\text { A Spatial-Temporal Method to Detect } \\
\text { Global Influenza Epidemics Using } \\
\text { Heterogeneous Data Collected from } \\
\text { the Internet }\end{array}$ & $\begin{array}{l}\text { Spatial-temporal method that } \\
\text { incorporates heterogeneous data } \\
\text { collected from the Internet to detect } \\
\text { influenza epidemics }\end{array}$ & TCBB & 2018 \\
\hline S18 & [47] & $\begin{array}{l}\text { A Spatio-GraphNet Model for Real-time } \\
\text { Contact Tracing of COVID-19 Infection in } \\
\text { Resource Limited Settings }\end{array}$ & $\begin{array}{l}\text { Spatio-GraphNet model for real-time } \\
\text { contact tracing of COVID-19 infection }\end{array}$ & ICMHI & 2020 \\
\hline S19 & [48] & $\begin{array}{l}\text { A wearable magnetic field based proximity } \\
\text { sensing system for monitoring COVID-19 } \\
\text { social distancing }\end{array}$ & $\begin{array}{l}\text { Wearable, oscillating magnetic } \\
\text { field-based proximity sensing system } \\
\text { to monitor social distancing }\end{array}$ & ISWC & 2020 \\
\hline S20 & [49] & $\begin{array}{l}\text { Active Surveillance for COVID-19 Through } \\
\text { Artificial Intelligence Using Real-Time } \\
\text { Speech-Recognition Mobile Application }\end{array}$ & $\begin{array}{c}\text { Model of active surveillance for } \\
\text { COVID-19 through artificial } \\
\text { intelligence }\end{array}$ & ICCE-Taiwan & 2020 \\
\hline $\mathrm{S} 21$ & [50] & $\begin{array}{l}\text { An Alternative Body Temperature } \\
\text { Measurement Solution: Combination of a } \\
\text { Highly Accurate Monitoring System and a } \\
\text { Visualized Public Health Cloud Platform }\end{array}$ & $\begin{array}{c}\text { Body temperature monitoring system } \\
\text { with a thermography based on IoT } \\
\text { architecture }\end{array}$ & $\begin{array}{l}\text { IEEE Internet } \\
\text { Things J }\end{array}$ & 2021 \\
\hline $\mathrm{S} 22$ & [51] & $\begin{array}{c}\text { An Autonomous Delivery Robot to Prevent } \\
\text { the Spread of Coronavirus in Product } \\
\text { Delivery System }\end{array}$ & $\begin{array}{l}\text { Prototype robot to reduce the risk of } \\
\text { infectious disease transmission in the } \\
\text { product delivery system }\end{array}$ & UEMCON & 2020 \\
\hline $\mathrm{S} 23$ & [52] & $\begin{array}{l}\text { An Efficient Immunization Strategy Using } \\
\text { Overlapping Nodes and Its Neighborhoods }\end{array}$ & $\begin{array}{l}\text { Address the effect of nodes in the } \\
\text { neighborhood of the overlapping } \\
\text { nodes on epidemics spreading }\end{array}$ & $\begin{array}{l}\text { WWW } \\
\text { Companion }\end{array}$ & 2018 \\
\hline $\mathrm{S} 24$ & [53] & $\begin{array}{c}\text { An emerging innovative uv disinfection } \\
\text { technology (Part ii): Virucide activity on } \\
\text { SARS-CoV-2 }\end{array}$ & $\begin{array}{l}\text { UV chip technology adoption in viral } \\
\text { charge reduction }\end{array}$ & IJERPH & 2021 \\
\hline $\mathrm{S} 25$ & [54] & $\begin{array}{l}\text { An enhanced, contactless, IoT based } \\
\text { operation of power appliances for } \\
\text { COVID-19 isolation zone }\end{array}$ & $\begin{array}{l}\text { IoT adoption for power appliances } \\
\text { devices without physical contact }\end{array}$ & JGE & 2020 \\
\hline S26 & [55] & $\begin{array}{c}\text { An integrated biosensor system with } \\
\text { mobile health and wastewater-based } \\
\text { epidemiology (iBMW) for COVID-19 } \\
\text { pandemic }\end{array}$ & $\begin{array}{c}\text { Integrated biosensor system with } \\
\text { mobile health and wastewater-based } \\
\text { epidemiology }\end{array}$ & JBSBE & 2020 \\
\hline $\mathrm{S} 27$ & [56] & $\begin{array}{c}\text { An Intelligent and Energy-Efficient } \\
\text { Wireless Body Area Network to Control } \\
\text { Coronavirus Outbreak }\end{array}$ & $\begin{array}{l}\text { Novel coronavirus-body area } \\
\text { network model based on IoT } \\
\text { technology monitoring system for the } \\
\text { detection of coronavirus infection }\end{array}$ & Arab J Sci Eng. & 2021 \\
\hline S28 & [57] & $\begin{array}{c}\text { An Interactive Web-based Decision } \\
\text { Support System for Mass Dispensing, } \\
\text { Emergency Preparedness, and } \\
\text { Biosurveillance }\end{array}$ & $\begin{array}{l}\text { Interactive web-based real-time } \\
\text { decision support suite that allow } \\
\text { public health emergency } \\
\text { preparedness coordinators }\end{array}$ & $\mathrm{DH}$ & 2017 \\
\hline S29 & [58] & $\begin{array}{l}\text { An Interactive, Web-Based High } \\
\text { Performance Modeling Environment for } \\
\text { Computational Epidemiology }\end{array}$ & $\begin{array}{l}\text { An integrated interactive modeling } \\
\text { environment to support public health } \\
\text { epidemiology }\end{array}$ & TMIS & 2014 \\
\hline $\mathrm{S} 30$ & [59] & $\begin{array}{c}\text { An Internet of Things Paradigm: Pandemic } \\
\text { Management (incl. COVID-19) }\end{array}$ & $\begin{array}{l}\text { IoT paradigm to strengthen the } \\
\text { old-style public health measures }\end{array}$ & ICAIS & 2021 \\
\hline
\end{tabular}


Table A1. Cont.

\begin{tabular}{|c|c|c|c|c|c|}
\hline ID & Reference & Title & Approach & $\begin{array}{l}\text { Venue } \\
\text { Acronym }\end{array}$ & Year \\
\hline S31 & {$[60]$} & $\begin{array}{l}\text { An IoT-Cloud Based Health Monitoring } \\
\text { Wearable Device for COVID Patients }\end{array}$ & $\begin{array}{l}\text { Use of mobile apps and remote health } \\
\text { monitoring system that uses IoT for } \\
\text { health diagnosis }\end{array}$ & ICACCS & 2021 \\
\hline S32 & {$[61]$} & $\begin{array}{l}\text { Analysis of 2019-nCoV epidemic situation } \\
\text { based on modified SEIR model and DSGE } \\
\text { algorithm }\end{array}$ & $\begin{array}{c}\text { Prediction model based on the SEIR } \\
\text { infectious disease transmission model } \\
\text { to help prediction of the pandemic } \\
\text { outbreak }\end{array}$ & ISCTT & 2020 \\
\hline S33 & {$[62]$} & $\begin{array}{c}\text { Analysis of COVID-19 Tracking Tool in } \\
\text { India: Case Study of Aarogya Setu Mobile } \\
\text { Application }\end{array}$ & $\begin{array}{l}\text { Exploration of a mobile technology } \\
\text { for tracking or contact tracing }\end{array}$ & DGOV & 2020 \\
\hline S34 & {$[63]$} & $\begin{array}{l}\text { Application of semantic location awareness } \\
\text { computing based on data mining in } \\
\text { COVID-19 prevention and control system }\end{array}$ & $\begin{array}{l}\text { Spatiotemporal trajectory data } \\
\text { mining method application in } \\
\text { epidemic prevention and monitoring }\end{array}$ & $\begin{array}{l}\text { J. Intell. Fuzzy } \\
\text { Syst. }\end{array}$ & 2020 \\
\hline S35 & {$[64]$} & $\begin{array}{l}\text { Apply IOT technology to practice a } \\
\text { pandemic prevention body temperature } \\
\text { measurement system: A case study of } \\
\text { response measures for COVID-19 }\end{array}$ & $\begin{array}{c}\text { Intelligent pandemic prevention } \\
\text { Temperature Measurement System } \\
\text { and Pandemic Prevention situation } \\
\text { Analysis System }\end{array}$ & IJDSN & 2021 \\
\hline S36 & {$[65]$} & $\begin{array}{l}\text { Approaching multi-dimensional cube for } \\
\text { visualization-based epidemic warning } \\
\text { system-dengue fever }\end{array}$ & $\begin{array}{c}\text { Visualization-based warning system } \\
\text { to control the development of } \\
\text { epidemic }\end{array}$ & ICUIMC & 2014 \\
\hline S37 & {$[66]$} & $\begin{array}{c}\text { Assisted Telemedicine Model for Rural } \\
\text { Healthcare Ecosystem }\end{array}$ & $\begin{array}{l}\text { Assisted Telemedicine model and app } \\
\text { for Rural Healthcare Ecosystem }\end{array}$ & WebSci & 2021 \\
\hline S38 & [67] & $\begin{array}{l}\text { AT89S52-Microcontroller Based Elevator } \\
\text { with UV-C disinfection to prevent the } \\
\text { transmission of COVID-19 }\end{array}$ & $\begin{array}{l}\text { System for the automatic disinfection } \\
\text { of elevator cabins using UV-C light }\end{array}$ & ICPS & 2020 \\
\hline S39 & [68] & $\begin{array}{c}\text { Automated AMBU Ventilator with } \\
\text { Negative Pressure Headbox and } \\
\text { Transporting Capsule for COVID-19 } \\
\text { Patient Transfer }\end{array}$ & Automated AMBU ventilator & $\begin{array}{l}\text { Front. Robot. } \\
\text { AI }\end{array}$ & 2021 \\
\hline S40 & [69] & $\begin{array}{l}\text { Avoid Touching Your Face: A Hand-to-face } \\
\text { 3D Motion Dataset (COVID-away) and } \\
\text { Trained Models for Smartwatches }\end{array}$ & $\begin{array}{l}\text { COVID-away dataset and trained } \\
\text { models }\end{array}$ & $\begin{array}{c}\text { IoT } \\
\text { Companion }\end{array}$ & 2020 \\
\hline S41 & {$[70]$} & $\begin{array}{c}\text { Be Aware of the Hot Zone: A Warning } \\
\text { System of Hazard Area Prediction to } \\
\text { Intervene Novel Coronavirus COVID-19 } \\
\text { Outbreak }\end{array}$ & $\begin{array}{l}\text { Warning system to predict hazard } \\
\text { areas in order to } \\
\text { intervene the novel coronavirus } \\
\text { COVID-19 epidemic transmission }\end{array}$ & SIGIR & 2020 \\
\hline S42 & {$[71]$} & $\begin{array}{c}\text { Big Data Analytics Framework for } \\
\text { Childhood Infectious Disease Surveillance } \\
\text { and Response System using Modified } \\
\text { MapReduce Algorithm A Case Study of } \\
\text { Tanzania }\end{array}$ & $\begin{array}{c}\text { Framework for Childhood Infectious } \\
\text { Disease Surveillance and Response } \\
\text { System }\end{array}$ & IJACSA & 2021 \\
\hline S43 & {$[72]$} & $\begin{array}{l}\text { Blockchain-enabled secure communication } \\
\text { for drone delivery: a case study in } \\
\text { COVID-like scenarios }\end{array}$ & $\begin{array}{c}\text { Blockchain-enabled secure } \\
\text { communication framework for } \\
\text { delivering the goods in COVID-19 } \\
\text { like scenarios }\end{array}$ & MobiCom & 2020 \\
\hline S44 & [73] & $\begin{array}{l}\text { Bridging Predictive Analytics and Mobile } \\
\text { Crowdsensing for Future Risk Maps of } \\
\text { Communities Against COVID-19 }\end{array}$ & $\begin{array}{c}\text { MCS-driven community risk } \\
\text { modeling solution against COVID-19 } \\
\text { pandemic }\end{array}$ & MobiWac & 2020 \\
\hline S45 & {$[74]$} & $\begin{array}{l}\text { Can artificial intelligence enable the } \\
\text { government to respond more effectively to } \\
\text { major public health emergencies? Taking } \\
\text { the prevention and control of COVID-19 in } \\
\text { China as an example }\end{array}$ & $\begin{array}{l}\text { 3S technology adoption to propose } \\
\text { the establishment of an emergency } \\
\text { command platform for public health } \\
\text { emergencies }\end{array}$ & $\begin{array}{l}\text { Socio-Econ. } \\
\text { Plan. Sci. }\end{array}$ & 2021 \\
\hline S46 & [75] & $\begin{array}{l}\text { Characterizing the spread of COVID-19 } \\
\text { from human mobility patterns and } \\
\text { SocioDemographic indicators }\end{array}$ & $\begin{array}{l}\text { Adoption of human mobility patterns } \\
\text { and SocioDemographic indicators to } \\
\text { examine the overall spread of } \\
\text { COVID-19 at local spatial scales }\end{array}$ & SIGSPATIAL & 2020 \\
\hline
\end{tabular}


Table A1. Cont.

\begin{tabular}{|c|c|c|c|c|c|}
\hline ID & Reference & Title & Approach & $\begin{array}{l}\text { Venue } \\
\text { Acronym }\end{array}$ & Year \\
\hline S47 & [76] & CNN Based COVID-19 Prevention System & $\begin{array}{c}\text { Artificial intelligent IoT system with } \\
\text { temperature monitoring and mask } \\
\text { detection }\end{array}$ & ICAIS & 2021 \\
\hline S48 & [77] & $\begin{array}{l}\text { Cola-GNN: Cross-location Attention based } \\
\text { Graph Neural Networks for Long-term ILI } \\
\text { Prediction }\end{array}$ & $\begin{array}{l}\text { Cross-location attention-based graph } \\
\text { neural network for learning time } \\
\text { series embeddings in long-term } \\
\text { influenza-like illness predictions }\end{array}$ & CIKM & 2020 \\
\hline S49 & {$[78]$} & $\begin{array}{l}\text { Contact tracing in healthcare digital } \\
\text { ecosystems for infectious disease control } \\
\text { and quarantine management }\end{array}$ & $\begin{array}{l}\text { Novel approach for contact tracing to } \\
\text { find the clusters of cases and the } \\
\text { infection tree for SARS automatically }\end{array}$ & DEST & 2009 \\
\hline S50 & [79] & $\begin{array}{c}\text { Contactless and context-aware decision } \\
\text { making for automated building access } \\
\text { systems }\end{array}$ & $\begin{array}{c}\text { Context-aware building access } \\
\text { system to improve infection control } \\
\text { measures }\end{array}$ & CAADRIA & 2021 \\
\hline S51 & {$[80]$} & Containing acute disease outbreak & $\begin{array}{c}\text { Development of a Geographical } \\
\text { Information System for the } \\
\text { containment of acute infectious } \\
\text { diseases }\end{array}$ & $\begin{array}{l}\text { Methods Inf. } \\
\text { Med. }\end{array}$ & 2005 \\
\hline S52 & [81] & $\begin{array}{l}\text { Controlling the Outbreak of COVID-19: } \\
\text { A Noncooperative Game Perspective }\end{array}$ & $\begin{array}{l}\text { noncooperative game to incentive } \\
\text { social distancing to prevent the } \\
\text { spread of COVID-19 }\end{array}$ & IEEE Access & 2020 \\
\hline S53 & [82] & $\begin{array}{l}\text { Controlling the Spreads of Infectious } \\
\text { Disease and Scare via Utilizing Location } \\
\text { and Social Networking Information }\end{array}$ & $\begin{array}{l}\text { Location and social networking } \\
\text { information adoption to control the } \\
\text { spread of infectious disease and } \\
\text { the scare }\end{array}$ & Mobidata & 2015 \\
\hline S54 & [83] & $\begin{array}{c}\text { Convergence model of } \mathrm{AI} \text { and IoT for virus } \\
\text { disease control system }\end{array}$ & $\begin{array}{c}\text { Virus disease control system using an } \\
\text { IoT / AI convergence model to } \\
\text { proactively detect and warn of risk } \\
\text { factors in response to infectious } \\
\text { diseases }\end{array}$ & $\begin{array}{l}\text { Pers. } \\
\text { Ubiquitous } \\
\text { Comput. }\end{array}$ & 2021 \\
\hline S55 & [84] & $\begin{array}{c}\text { Coronavirus Epidemic (COVID-19) } \\
\text { Prediction and Trend Analysis Based on } \\
\text { Time Series }\end{array}$ & $\begin{array}{l}\text { Machine Learning application for } \\
\text { epidemic development prediction }\end{array}$ & AIID & 2021 \\
\hline S56 & [85] & $\begin{array}{c}\text { Cost-Effective Device for Autonomous } \\
\text { Monitoring of the Vitals for COVID-19 } \\
\text { Asymptomatic Patients in Home Isolation } \\
\text { Treatment }\end{array}$ & $\begin{array}{l}\text { Healthcare system for body vitals } \\
\text { infection analysis }\end{array}$ & CoCoNet & 2021 \\
\hline S57 & [86] & $\begin{array}{l}\text { COVID Detection from Chest X-rays with } \\
\text { DeepLearning: CheXNet }\end{array}$ & $\begin{array}{l}\text { Model for COVID prediction from } \\
\text { chest X-rays using CheXNet }\end{array}$ & ICCCS & 2020 \\
\hline S58 & [87] & $\begin{array}{l}\text { COVID-19 Chest CT Image Segmentation } \\
\text { Network by Multi-Scale Fusion and } \\
\text { Enhancement Operations }\end{array}$ & $\begin{array}{l}\text { Deep convolutional neural network } \\
\text { tailored for segmenting the chest CT } \\
\text { images with COVID-19 infections }\end{array}$ & $\begin{array}{l}\text { IEEE Trans. } \\
\text { Big Data }\end{array}$ & 2021 \\
\hline S59 & [88] & $\begin{array}{l}\text { COVID-19 Chest Radiography Images } \\
\text { Analysis Based on Integration of Image } \\
\text { Preprocess, Guided Grad-CAM, Machine } \\
\text { Learning and Risk Management }\end{array}$ & $\begin{array}{l}\text { Methodology for chest radiography } \\
\text { images application, as one of } \\
\text { workable alarm and analysis systems } \\
\text { to support clinicians against } \\
\text { COVID-19 outbreak threat }\end{array}$ & ICMHI & 2020 \\
\hline S60 & [89] & $\begin{array}{l}\text { COVID-19 CT Image Recognition Based on } \\
\text { Multi-stage Transfer Learning }\end{array}$ & $\begin{array}{l}\text { Deep learning adoption to } \\
\text { automatically distinguish subjects' } \\
\text { lung CT images to assist in the } \\
\text { diagnosis of COVID-19 }\end{array}$ & ICASIT & 2020 \\
\hline S61 & [90] & $\begin{array}{c}\text { COVID-19 Detection Based on Image } \\
\text { Regrouping and Resnet-SVM Using Chest } \\
\text { X-ray Images }\end{array}$ & $\begin{array}{l}\text { Combination of image regrouping } \\
\text { and ResNet-SVM to detect COVID-19 } \\
\text { in chest X-ray images }\end{array}$ & EMBS & 2021 \\
\hline S62 & [91] & $\begin{array}{c}\text { COVID-19 Joint Pandemic Modeling and } \\
\text { Analysis Platform }\end{array}$ & $\begin{array}{c}\text { All-encompassing operational } \\
\text { platform for non-pharmaceutical } \\
\text { interventions to the COVID-19 } \\
\text { pandemic }\end{array}$ & SIGSPATIAL & 2020 \\
\hline
\end{tabular}


Table A1. Cont.

\begin{tabular}{|c|c|c|c|c|c|}
\hline ID & Reference & Title & Approach & $\begin{array}{l}\text { Venue } \\
\text { Acronym }\end{array}$ & Year \\
\hline S63 & [92] & $\begin{array}{l}\text { COVID-19 Pandemic Prevention Mobile } \\
\text { Application for on Campus Classroom }\end{array}$ & $\begin{array}{l}\text { Mobile application for COVID-19 } \\
\text { Pandemic Prevention }\end{array}$ & ICCCS & 2021 \\
\hline S64 & [93] & $\begin{array}{l}\text { COVID-19 Pneumonia Detection in Chest } \\
\text { X-ray Images Using Transfer Learning of } \\
\text { Convolutional Neural Networks }\end{array}$ & $\begin{array}{l}\text { Adopt CNN Model to diagnose the } \\
\text { chest X-ray images of patients who } \\
\text { have pneumonia by COVID-19 }\end{array}$ & DSIT & 2020 \\
\hline S65 & [94] & $\begin{array}{l}\text { COVID-19 Recognition Based on Patient's } \\
\text { Coughing and Breathing Patterns Analysis: } \\
\text { Deep Learning Approach }\end{array}$ & $\begin{array}{l}\text { Deep LSTM technique to diagnose } \\
\text { and detect COVID-19 infection from } \\
\text { cough, breath, and sneeze signals }\end{array}$ & FRUCT & 2021 \\
\hline S66 & [95] & COVID-19 Spread Prediction Model & COVID-19 Spread Prediction Model & CONFCDS & 2021 \\
\hline S67 & [96] & $\begin{array}{l}\text { COVID-19: A Novel Framework to } \\
\text { Globally Track Coronavirus Infected } \\
\text { Patients using Blockchain }\end{array}$ & $\begin{array}{c}\text { Novel blockchain-based framework } \\
\text { that integrates intercountry for } \\
\text { COVID-19 to track infected or tested } \\
\text { patients globally }\end{array}$ & ICCI & 2020 \\
\hline S68 & [97] & $\begin{array}{l}\text { COVID-19: Update, Forecast and } \\
\text { Assistant-An Interactive Web Portal to } \\
\text { Provide Real-Time Information and } \\
\text { Forecast COVID-19 Cases in Bangladesh }\end{array}$ & $\begin{array}{l}\text { Informative and prediction-based } \\
\text { web portal }\end{array}$ & ICICT4SD & 2021 \\
\hline S69 & [98] & COVID-19's Telemedicine Platform & $\begin{array}{l}\text { Telehealth solution to support social } \\
\text { distance control, effective contact } \\
\text { detection, continuous monitoring of } \\
\text { people's health status }\end{array}$ & ICISA & 2021 \\
\hline S70 & [99] & $\begin{array}{l}\text { CovidSense: A Smartphone-based } \\
\text { Initiative for Fighting COVID-19 Spreading } \\
\text { CoviReader: Using IOTA and QR Code }\end{array}$ & $\begin{array}{l}\text { Smartphone-based app to provide a } \\
\text { reliable COVID-19 risk index } \\
\text { Decentralized healthcare }\end{array}$ & DSAI & 2020 \\
\hline S71 & [100] & $\begin{array}{c}\text { Technology to Control Epidemic Diseases } \\
\text { across the US }\end{array}$ & $\begin{array}{l}\text { management system that shares } \\
\text { user's data anonymously }\end{array}$ & CCWC & 2021 \\
\hline S72 & [101] & $\begin{array}{l}\text { COVTrac: COVID-19 Tracker and Social } \\
\text { Distancing App }\end{array}$ & $\begin{array}{l}\text { COVID-19 tracker and social } \\
\text { distancing app }\end{array}$ & ICACIE & 2020 \\
\hline S73 & [102] & $\begin{array}{c}\text { COWAR: An Android Based Mobile } \\
\text { Application to Help Citizens and } \\
\text { COVID-19 Warriors }\end{array}$ & $\begin{array}{l}\text { Mobile application to track the } \\
\text { spread of the COVID-19 }\end{array}$ & CICT & 2020 \\
\hline S74 & [103] & $\begin{array}{c}\text { Deep learning based mask detection in } \\
\text { smart home entries during the epidemic } \\
\text { process }\end{array}$ & $\begin{array}{l}\text { Design of deep learning-based mask } \\
\text { detection in smart home system }\end{array}$ & SCA & 2020 \\
\hline S75 & [104] & $\begin{array}{c}\text { Deep Learning Framework for Face Mask } \\
\text { Detection }\end{array}$ & $\begin{array}{l}\text { Face detection model for face mask } \\
\text { detection in video streams }\end{array}$ & ICOEI & 2021 \\
\hline S76 & [105] & $\begin{array}{c}\text { Deep Learning Implementation of } \\
\text { Facemask Detection }\end{array}$ & Real-time mask detection method & CONFCDS & 2021 \\
\hline S77 & [106] & $\begin{array}{l}\text { Deployment of a smart handwashing } \\
\text { station in a school setting during the } \\
\text { COVID-19 pandemic: Field study }\end{array}$ & Smart handwashing station & JMIR & 2020 \\
\hline S78 & [107] & $\begin{array}{l}\text { Design and Evaluation of a System for } \\
\text { Decentralized Management of Solidarity } \\
\text { Actions during the COVID-19 Crisis }\end{array}$ & $\begin{array}{l}\text { Web system for Decentralized } \\
\text { Management of Solidarity Actions } \\
\text { during the COVID-19 Crisis }\end{array}$ & Appl. Sci. & 2020 \\
\hline S79 & [108] & $\begin{array}{l}\text { Design and implementation of a social } \\
\text { distancing and contact tracing wearable }\end{array}$ & $\begin{array}{l}\text { Implementation of a social distancing } \\
\text { and contact tracing wearable }\end{array}$ & CiSt & 2020 \\
\hline S80 & [109] & $\begin{array}{c}\text { Design of hexacopter UAV system for } \\
\text { disinfectant spraying }\end{array}$ & $\begin{array}{l}\text { UAV system as a disinfectant sprayer } \\
\text { with drone adoption }\end{array}$ & EIC & 2020 \\
\hline S81 & [110] & $\begin{array}{l}\text { Design of Infectious Disease Prevention } \\
\text { and Control Platform Based on Big Data } \\
\text { Analysis of Location Information }\end{array}$ & $\begin{array}{l}\text { Big data analysis platform for } \\
\text { individual positioning information }\end{array}$ & EITCE & 2020 \\
\hline S82 & [111] & $\begin{array}{l}\text { Design of Smart-Gate Based on Artificial } \\
\text { Intelligence Possibly for COVID-19 Early } \\
\text { Prevention at Public Area }\end{array}$ & $\begin{array}{l}\text { Artificial intelligence-based smart } \\
\text { gate and website integration }\end{array}$ & TSSA & 2020 \\
\hline S83 & [112] & $\begin{array}{l}\text { Designing a Multi-Agent Occupant } \\
\text { Simulation System to Support Facility } \\
\text { Planning and Analysis for COVID-19 }\end{array}$ & $\begin{array}{l}\text { Multi-agent occupancy simulation } \\
\text { system that helps people to } \\
\text { understand and evaluate risks } \\
\text { associated with virus transmission }\end{array}$ & DIS & 2021 \\
\hline
\end{tabular}


Table A1. Cont.

\begin{tabular}{|c|c|c|c|c|c|}
\hline ID & Reference & Title & Approach & $\begin{array}{l}\text { Venue } \\
\text { Acronym }\end{array}$ & Year \\
\hline S84 & [113] & $\begin{array}{l}\text { Designing for pandemics-A design } \\
\text { concept based on technology mediated } \\
\text { nudging for health behavior change }\end{array}$ & $\begin{array}{l}\text { Application that promotes health } \\
\text { behavior change based on Bluetooth } \\
\text { proximity estimation and } \\
\text { nudging theory }\end{array}$ & HICSS & 2021 \\
\hline S85 & [114] & $\begin{array}{l}\text { Detecting Spatial Clusters of Disease } \\
\text { Infection Risk Using Sparsely Sampled } \\
\text { Social Media Mobility Patterns }\end{array}$ & $\begin{array}{l}\text { New spatial scan methods to search } \\
\text { for spatial clusters of increased } \\
\text { infection risk }\end{array}$ & SIGSPATIAL & 2019 \\
\hline S86 & [115] & $\begin{array}{l}\text { Detection and monitoring of the } \\
\text { asymptotic COVID-19 patients using IoT } \\
\text { devices and sensors }\end{array}$ & $\begin{array}{l}\text { Detect and monitor the asymptotic } \\
\text { patients using IoT-based sensors }\end{array}$ & IJPCC & 2020 \\
\hline S87 & [116] & $\begin{array}{c}\text { Detection and Tracking Contagion using } \\
\text { IoT-Edge Technologies: Confronting } \\
\text { COVID-19 Pandemic }\end{array}$ & $\begin{array}{l}\text { Smart edge surveillance system to } \\
\text { help to detect and track the } \\
\text { contagious person }\end{array}$ & ICECCE & 2020 \\
\hline S88 & [117] & $\begin{array}{c}\text { Detection of COVID-19 in Chest X-ray } \\
\text { Image using CLAHE and Convolutional } \\
\text { Neural Network }\end{array}$ & $\begin{array}{l}\text { COVID-19 detection in Chest } \\
\text { X-ray Images }\end{array}$ & ICORIS & 2020 \\
\hline S89 & [118] & $\begin{array}{c}\text { Detection of SARS-CoV-2 in the air of two } \\
\text { hospitals in Hermosillo, Sonora, México, } \\
\text { utilizing a low-cost environmental } \\
\text { monitoring system }\end{array}$ & $\begin{array}{l}\text { Filtration system with vacuum pump } \\
\text { for detecting the COVID-19 virus }\end{array}$ & IJID & 2021 \\
\hline S90 & [119] & $\begin{array}{l}\text { Developing Smart COVID-19 Social } \\
\text { Distancing Surveillance Drone using } \\
\text { YOLO Implemented in Robot Operating } \\
\text { System simulation environment }\end{array}$ & $\begin{array}{l}\text { COVID-19 Social Distancing } \\
\text { Surveillance system }\end{array}$ & R10-HTC & 2020 \\
\hline S91 & [120] & $\begin{array}{l}\text { Development and application of } \\
\text { agent-based disease spread simulation } \\
\text { model: the case of suwon, Korea }\end{array}$ & $\begin{array}{l}\text { Agent-based disease diffusion model } \\
\text { that reflects the nature of the disease } \\
\text { and the structural and statistical } \\
\text { characteristics of population }\end{array}$ & WSC & 2017 \\
\hline S92 & [121] & $\begin{array}{c}\text { Development of The Personnel Monitoring } \\
\text { System Using Mobile Application and } \\
\text { Real-Time Database During the COVID19 } \\
\text { Pandemic }\end{array}$ & $\begin{array}{l}\text { Real-time monitoring and command } \\
\text { system using mobile applications and } \\
\text { cloud computing technology }\end{array}$ & ISRITI & 2020 \\
\hline S93 & [122] & $\begin{array}{l}\text { Digital health technologies respond to the } \\
\text { COVID-19 pandemic in a tertiary hospital } \\
\text { in China: Development and usability study }\end{array}$ & $\begin{array}{l}\text { Web-based COVID-19 service } \\
\text { platform }\end{array}$ & JMIR & 2020 \\
\hline S94 & [123] & $\begin{array}{l}\text { Digital proximity tracing on empirical } \\
\text { contact networks for pandemic control }\end{array}$ & $\begin{array}{l}\text { Framework informed by empirical } \\
\text { high-resolution contact data to } \\
\text { analyze the impact of digital contact } \\
\text { tracing in the COVID-19 pandemic }\end{array}$ & Nat. Commun. & 2021 \\
\hline S95 & [124] & $\begin{array}{c}\text { Disinfection of Klebsiella pneumoniae } \\
\text { using ultrasonic systems }\end{array}$ & $\begin{array}{l}\text { Disinfection of Klebsiella } \\
\text { pneumoniae using ultrasonic systems }\end{array}$ & J. Environ. Biol. & 2016 \\
\hline S96 & [125] & $\begin{array}{c}\text { Dynamic multiplex social network models } \\
\text { on multiple time scales for simulating } \\
\text { contact formation and patterns in } \\
\text { epidemic spread }\end{array}$ & $\begin{array}{l}\text { Model for dynamic networks of } \\
\text { physical contacts and their } \\
\text { application for reproducing complex } \\
\text { patterns in epidemic spread }\end{array}$ & WSC & 2017 \\
\hline S97 & [126] & $\begin{array}{l}\text { Dynamical SEIR Model with Information } \\
\text { Entropy Using COVID-19 as a Case Study }\end{array}$ & $\begin{array}{l}\text { SEIR model that incorporates social } \\
\text { media into disease spread dynamics, } \\
\text { and allow epidemic spread } \\
\text { simulation to facilitate prediction }\end{array}$ & $\begin{array}{l}\text { IEEE Trans. } \\
\text { Comput. Soc. } \\
\text { Syst. }\end{array}$ & 2021 \\
\hline S98 & [127] & $\begin{array}{c}\text { Economic Evaluation of Quarantine: } \\
\text { A Case Study of COVID-19 Pandemic } \\
\text { in Belgium }\end{array}$ & $\begin{array}{l}\text { SEIR-based simulation model to } \\
\text { predict the disease transmission }\end{array}$ & ICIIBMS & 2020 \\
\hline S99 & [128] & $\begin{array}{l}\text { Effective real-time allocation of pandemic } \\
\text { interventions }\end{array}$ & $\begin{array}{c}\text { Agent based model for simulating the } \\
\text { diffusion of pandemic influenza via } \\
\text { carefully calibrated inter-city } \\
\text { airline travel }\end{array}$ & WSC & 2010 \\
\hline
\end{tabular}


Table A1. Cont.

\begin{tabular}{|c|c|c|c|c|c|}
\hline ID & Reference & Title & Approach & $\begin{array}{l}\text { Venue } \\
\text { Acronym }\end{array}$ & Year \\
\hline S100 & [129] & $\begin{array}{c}\text { E-health: agent-based models to simulate } \\
\text { behavior of individuals during an } \\
\text { epidemic outbreak }\end{array}$ & $\begin{array}{l}\text { Agent based model of behavior and } \\
\text { activities of individuals }\end{array}$ & DG.O & 2018 \\
\hline S101 & [130] & $\begin{array}{c}\text { Epidemic Propagation with Positive and } \\
\text { Negative Preventive Information in } \\
\text { Multiplex Networks }\end{array}$ & $\begin{array}{l}\text { Epidemic model to explore the } \\
\text { characteristics of epidemic } \\
\text { propagation under the impact of } \\
\text { positive and negative prevention } \\
\text { information }\end{array}$ & $\begin{array}{l}\text { IEEE Trans } \\
\text { Cybern }\end{array}$ & 2021 \\
\hline S102 & [131] & $\begin{array}{l}\text { EpiSimdemics: an efficient algorithm for } \\
\text { simulating the spread of infectious disease } \\
\text { over large realistic social networks }\end{array}$ & $\begin{array}{l}\text { Scalable parallel algorithm to } \\
\text { simulate the spread of contagion in } \\
\text { large, realistic social contact networks }\end{array}$ & SC & 2008 \\
\hline S103 & [132] & $\begin{array}{c}\text { Exploiting Social Media to enhance Clinical } \\
\text { Decision Support }\end{array}$ & $\begin{array}{l}\text { Clinical Decision Support System to } \\
\text { assist diagnosing or treating patients }\end{array}$ & WI Companion & 2019 \\
\hline S104 & [133] & $\begin{array}{c}\text { Exploring Automatic Diagnosis of } \\
\text { COVID-19 from Crowdsourced } \\
\text { Respiratory Sound Data }\end{array}$ & $\begin{array}{c}\text { Crowdsource respiratory sounds and } \\
\text { study how such data may aid } \\
\text { COVID-19 diagnosis }\end{array}$ & KDD & 2020 \\
\hline S105 & [134] & $\begin{array}{c}\text { Extraction of disease events for a real-time } \\
\text { monitoring system }\end{array}$ & $\begin{array}{c}\text { Semantic rules and machine learning } \\
\text { adoption to extract infectious } \\
\text { disease events }\end{array}$ & SoICT & 2014 \\
\hline S106 & [135] & $\begin{array}{c}\text { Face Mask Detection using Convolutional } \\
\text { Neural Network (CNN) to reduce the } \\
\text { spread of COVID-19 }\end{array}$ & $\begin{array}{l}\text { Deep learning methods adoption for } \\
\text { face mask detection }\end{array}$ & ICOEI & 2021 \\
\hline S107 & [136] & Face Mask Detection Using Deep Learning & $\begin{array}{l}\text { Deep learning methods adoption for } \\
\text { face mask detection }\end{array}$ & ICCCI & 2021 \\
\hline S108 & [137] & $\begin{array}{c}\text { Face mask detection using YOLOv3 and } \\
\text { faster R-CNN models: COVID-19 } \\
\text { environment }\end{array}$ & $\begin{array}{l}\text { Face mask detection using YOLOv3 } \\
\text { and faster R-CNN models }\end{array}$ & $\begin{array}{l}\text { Multimed } \\
\text { Tools Appl }\end{array}$ & 2021 \\
\hline S109 & [138] & $\begin{array}{c}\text { FaceLock Homes: A Contactless Smart } \\
\text { Home Security System to Prevent COVID } \\
\text { Transmission }\end{array}$ & $\begin{array}{l}\text { IoT adoption to unauthorized access } \\
\text { restriction system in home security, } \\
\text { and human screening check for } \\
\text { COVID transmission prevention }\end{array}$ & WiSPNET & 2021 \\
\hline S110 & [139] & $\begin{array}{c}\text { Facing COVID-19 pandemic: Development } \\
\text { of custom-made face mask with rapid } \\
\text { prototyping system }\end{array}$ & $\begin{array}{l}\text { 3D printing technology adoption for } \\
\text { personal protective equipment } \\
\text { construction for healthcare } \\
\text { professionals }\end{array}$ & JIDC & 2021 \\
\hline S111 & [140] & $\begin{array}{c}\text { Fast Containment of Infectious Diseases } \\
\text { with E-healthcare Mobile Social Internet } \\
\text { of Things }\end{array}$ & $\begin{array}{l}\text { Healthcare mobile social internet of } \\
\text { things based targeted vaccination } \\
\text { scheme to fast contain the spread of } \\
\text { the infectious disease }\end{array}$ & $\begin{array}{l}\text { IEEE Internet } \\
\text { Things J }\end{array}$ & 2021 \\
\hline S112 & [141] & $\begin{array}{l}\text { Fine-Tuning A Lightweight Convolutional } \\
\text { Neural Networks for COVID-19 Diagnosis }\end{array}$ & $\begin{array}{l}\text { Deep learning adoption s for } \\
\text { automatic COVID-19 diagnosis in } \\
\text { chest X-ray image datasets }\end{array}$ & CSBio & 2020 \\
\hline S113 & [142] & $\begin{array}{c}\text { First prototype of the infectious diseases } \\
\text { seeker (IDS) software for prompt } \\
\text { identification of infectious diseases }\end{array}$ & $\begin{array}{l}\text { Infectious disease regressive } \\
\text { prediction tool }\end{array}$ & JEGH & 2020 \\
\hline S114 & [143] & $\begin{array}{l}\text { FluSense: A Contactless Syndromic } \\
\text { Surveillance Platform for Influenza-Like } \\
\text { Illness in Hospital Waiting Areas }\end{array}$ & $\begin{array}{l}\text { Contactless syndromic surveillance } \\
\text { platform FluSens }\end{array}$ & IMWUT & 2020 \\
\hline S115 & [144] & $\begin{array}{l}\text { Fluspot: Seasonal flu tracking app } \\
\text { exploiting wearable IoT device for } \\
\text { symptoms monitoring }\end{array}$ & $\begin{array}{l}\text { Application development and IoT } \\
\text { adoption to contribute to virus } \\
\text { prevention }\end{array}$ & $\begin{array}{l}\text { SEEDA- } \\
\text { CECNSM }\end{array}$ & 2020 \\
\hline S116 & [145] & $\begin{array}{c}\text { Forecasting Seasonal Influenza Fusing } \\
\text { Digital Indicators and a Mechanistic } \\
\text { Disease Model }\end{array}$ & $\begin{array}{c}\text { Seasonal influenza forecast } \\
\text { framework based on a stochastic, } \\
\text { spatially structured } \\
\text { mechanistic model }\end{array}$ & $\begin{array}{l}\text { WWW } \\
\text { Companion }\end{array}$ & 2017 \\
\hline
\end{tabular}


Table A1. Cont.

\begin{tabular}{|c|c|c|}
\hline ID & Reference & Title \\
\hline S117 & [146] & $\begin{array}{l}\text { GeoAI-based Epidemic Control with } \\
\text { Geo-Social Data Sharing on Blockchain }\end{array}$ \\
\hline S118 & [147] & $\begin{array}{l}\text { Handheld plasmonic biosensor for virus } \\
\text { detection in field-settings }\end{array}$ \\
\hline S119 & [148] & $\begin{array}{c}\text { Heuristic Evaluation of an African-centric } \\
\text { Mobile Persuasive Game for Promoting } \\
\text { Safety Measures Against COVID-19 }\end{array}$ \\
\hline S120 & [149] & $\begin{array}{c}\text { Hi-COVIDNet: Deep Learning Approach } \\
\text { to Predict Inbound COVID-19 Patients and } \\
\text { Case Study in South Korea }\end{array}$ \\
\hline S121 & [150] & $\begin{array}{c}\text { Human Face Recognition and Temperature } \\
\text { Measurement Based on Deep Learning for } \\
\text { COVID-19 Quarantine Checkpoint }\end{array}$ \\
\hline S122 & [151] & $\begin{array}{l}\text { Human Temperature Scanning from } \\
\text { a Distance }\end{array}$ \\
\hline S123 & [152] & $\begin{array}{l}\text { IDispenser-big data enabled } \\
\text { intelligent dispenser }\end{array}$ \\
\hline
\end{tabular}

Improving infectious diseases prevention S124 [153] system: The case study of Departement of Health Sragen

S125 [154] $\begin{gathered}\text { Individual Decision Making Can Drive } \\ \text { Epidemics: A Fuzzy Cognitive Map Study }\end{gathered}$

Indoor air quality monitoring system for S126 [155] proactive control of respiratory infectious diseases: poster abstract
Infection Prevention and Control using UV-Disinfectant Bot for COVID

Infection Screening System Using Thermography and CCD Camera with

Good Stability and Swiftness for Non-contact Vital-Signs Measurement by Feature Matching and MUSIC Algorithm

\section{Infectious Diseases Spreading on an} Adaptive Metapopulation Network

Inferring Metapopulation Propagation Network for Intra-city Epidemic Control and Prevention

Initial development of "Infection defender": A children's educational game for pandemic prevention measurements
Infectious disease information sharing platform by combining the Blockchain, social apps, and Geospatial Artificial Intelligence

Biosensor that employs a plasmonic chip based on nanohole arrays integrated to a lensfree-imaging framework for label-free detection of viruses

Mobile game aimed at raising awareness on the importance of social distancing and other precautionary measures

Novel approach to address the problem of predicting imported COVID-19 cases

Method that combines body temperature measurement, facial recognition, and masking based on deep learning

Solution of measuring human temperature from a distance

Approach to prevent spread of airborne diseases through the application of Big Data Technologies and IoT Sensing

Early warning system for infectious diseases prevention

HEALTHCOM

Sens. Actuators

AfriCHI

KDD

ICFNDS

CSCI

BigDataService

Fuzzy cognitive map (FCM)

denotative model to consider individual behavior and its influence on individual decision making to prevent infections

Low-cost indoor air quality monitoring devices and systems to tackle the disease surveillance problem

Infection prevention method and Ultraviolet rays disinfection robots adoption for hospital sterilization

ICITSI

IEEE Trans Fuzzy Syst

Infectious diseases screening system using feature matching and MUSIC algorithm

Adaptive metapopulation network and risk indicator according to the relative infection density definition

Two-step method for intra-city epidemic propagation modeling on a metapopulation base

Game to promote children's awareness in spread of infectious diseases prevention measurements
IEEE Access

KDD

VISIGRAPP 
Table A1. Cont.

\begin{tabular}{|c|c|c|c|c|c|}
\hline ID & Reference & Title & Approach & $\begin{array}{l}\text { Venue } \\
\text { Acronym }\end{array}$ & Year \\
\hline S132 & [161] & $\begin{array}{l}\text { Integrated agent-oriented modeling and } \\
\text { simulation of population and healthcare } \\
\text { delivery network: application to COPD } \\
\text { chronic disease in a Canadian region }\end{array}$ & $\begin{array}{l}\text { Framework for integrated } \\
\text { agent-oriented modeling and } \\
\text { simulation of the population with a } \\
\text { specific chronic disease }\end{array}$ & WSC & 2010 \\
\hline S133 & [162] & $\begin{array}{c}\text { Intelligent Lighting System Design Based } \\
\text { on UV LED Technology with the Functions } \\
\text { of Air Sterilization, Disinfection, } \\
\text { Purification and Mosquito Control }\end{array}$ & $\begin{array}{l}\text { Integration of air elimination, } \\
\text { purification, and mosquito control } \\
\text { into commonly used lighting fixtures }\end{array}$ & $\begin{array}{l}\text { SSLChina: } \\
\text { IFWS }\end{array}$ & 2020 \\
\hline S134 & [163] & $\begin{array}{l}\text { IoT based COVID De-Escalation System } \\
\text { using Bluetooth Low Level Energy }\end{array}$ & $\begin{array}{l}\text { Monitor real time cases and prevent } \\
\text { the contagious spread of COVID }\end{array}$ & ICICT & 2021 \\
\hline S135 & [164] & $\begin{array}{c}\text { IoT Telemonitoring System for COVID-19 } \\
\text { Quarantine }\end{array}$ & $\begin{array}{l}\text { IoT telemonitoring system for } \\
\text { quarantine }\end{array}$ & TEM & 2021 \\
\hline S136 & [165] & $\begin{array}{l}\text { IoT-based GPS assisted surveillance system } \\
\text { with inter-WBAN geographic routing for } \\
\text { pandemic situations }\end{array}$ & $\begin{array}{l}\text { Surveillance system with IoT } \\
\text { applications and an inter-WBAN } \\
\text { geographic routing algorithm }\end{array}$ & JBI & 2021 \\
\hline S137 & [166] & $\begin{array}{c}\text { IVACS: Intelligent Voice Assistant for } \\
\text { Coronavirus Disease (COVID-19) } \\
\text { Self-Assessment }\end{array}$ & $\begin{array}{l}\text { Intelligent voice-based assistant for } \\
\text { COVID-19 self-assessment }\end{array}$ & ICAIMAT & 2020 \\
\hline S138 & [167] & $\begin{array}{c}\text { Link Analysis to Discover Insights from } \\
\text { Structured and Unstructured Data on } \\
\text { COVID-19 }\end{array}$ & $\begin{array}{l}\text { Mining method to answer the call to } \\
\text { action and help the science } \\
\text { community answer high-priority } \\
\text { scientific questions related to } \\
\text { SARS-CoV-2 }\end{array}$ & $\mathrm{BCB}$ & 2020 \\
\hline S139 & [168] & $\begin{array}{l}\text { Longitudinal remotely mentored } \\
\text { self-performed lung ultrasound } \\
\text { surveillance of paucisymptomatic } \\
\text { COVID-19 patients at risk of disease } \\
\text { progression }\end{array}$ & $\begin{array}{l}\text { Remotely tele mentored } \\
\text { self-performed ultrasound to monitor } \\
\text { people with COVID-19 risk } \\
\text { progression }\end{array}$ & J. Ultrasound & 2021 \\
\hline S140 & [169] & $\begin{array}{c}\text { Low-cost Robot Assistance Design for } \\
\text { Health Area to Help Prevent COVID-19 } \\
\text { in Honduras }\end{array}$ & $\begin{array}{l}\text { Robots design to perform simple } \\
\text { tasks in hospitals }\end{array}$ & ICRAI & 2020 \\
\hline S141 & [170] & $\begin{array}{l}\text { Machine learning framework for } \\
\text { COVID-19 diagnosis }\end{array}$ & $\begin{array}{l}\text { Machine learning application for } \\
\text { early diagnosis of disease and } \\
\text { continuous monitoring of } \\
\text { infected patients }\end{array}$ & DATA & 2021 \\
\hline S142 & [171] & $\begin{array}{l}\text { Mask Detection and Epidemic } \\
\text { Prevention System }\end{array}$ & $\begin{array}{l}\text { Face mask recognition and epidemic } \\
\text { prevention system }\end{array}$ & ICMSP & 2020 \\
\hline S143 & [172] & Mask Wearing Classification using CNN & $\begin{array}{l}\text { Deep learning based image } \\
\text { classification model to detect whether } \\
\text { a person is wearing a mask or not }\end{array}$ & ICAICTA & 2020 \\
\hline S144 & [173] & $\begin{array}{l}\text { Mask wearing detection method based on } \\
\text { SSD-Mask algorithm }\end{array}$ & $\begin{array}{l}\text { Method of face mask wearing } \\
\text { detection in natural scenes }\end{array}$ & ICCSMT & 2020 \\
\hline S145 & [174] & $\begin{array}{l}\text { MAS-SEIR-II Simulation on COVID-19 } \\
\text { in China }\end{array}$ & $\begin{array}{l}\text { Model based on regional geographic } \\
\text { information to hypothetically } \\
\text { simulate different epidemic } \\
\text { prevention and control scenarios }\end{array}$ & ICBDM & 2020 \\
\hline S146 & [175] & $\begin{array}{l}\text { Mathematical analysis of an SIR network } \\
\text { model with imperfect vaccination and } \\
\text { varying size of population }\end{array}$ & $\begin{array}{l}\text { Modified } \\
\text { susceptible-infected-recovered model } \\
\text { on homogeneous networks regarding } \\
\text { epidemic spreading }\end{array}$ & ICCMS & 2017 \\
\hline S147 & [176] & $\begin{array}{l}\text { Measles Metapopulation Modeling using } \\
\text { Ideal Flow of Transportation Networks }\end{array}$ & $\begin{array}{l}\text { Big data adoption in the monitoring } \\
\text { of measles propagation }\end{array}$ & ICSIM & 2019 \\
\hline S148 & [177] & $\begin{array}{c}\text { Medical imaging engineering and } \\
\text { technology branch of the chinese society of } \\
\text { biomedical engineering expert consensus } \\
\text { on the application of emergency mobile } \\
\text { cabin CT }\end{array}$ & $\begin{array}{l}\text { Emergency mobile cabin CT for scan } \\
\text { and diagnostic }\end{array}$ & $\begin{array}{l}\text { Quant Imaging } \\
\text { Med Surg }\end{array}$ & 2020 \\
\hline
\end{tabular}


Table A1. Cont.

\begin{tabular}{|c|c|c|c|c|c|}
\hline ID & Reference & Title & Approach & $\begin{array}{l}\text { Venue } \\
\text { Acronym }\end{array}$ & Year \\
\hline S149 & [178] & $\begin{array}{c}\text { Mining Spatiotemporal Diffusion Network: } \\
\text { A New Framework of Active Surveillance } \\
\text { Planning }\end{array}$ & $\begin{array}{l}\text { Framework of active surveillance } \\
\text { planning of infectious disease spread }\end{array}$ & IEEE Access & 2019 \\
\hline S150 & [179] & $\begin{array}{l}\text { Mobile support for diagnosis of } \\
\text { communicable diseases in remote locations }\end{array}$ & $\begin{array}{l}\text { Mobile system adoption to assist } \\
\text { health professionals with diagnosis of } \\
\text { emerging and neglected diseases }\end{array}$ & CHINZ & 2012 \\
\hline S151 & [180] & $\begin{array}{l}\text { Mobile tools for point-of-care diagnostics } \\
\text { in the developing world }\end{array}$ & $\begin{array}{l}\text { Smartphone application for rapid } \\
\text { diagnostic tests }\end{array}$ & ACM DEV & 2013 \\
\hline S152 & [181] & $\begin{array}{l}\text { Mobilenet mask: A multi-phase face mask } \\
\text { detection model to prevent } \\
\text { person-to-person transmission of } \\
\text { SARS-CoV-2 }\end{array}$ & $\begin{array}{l}\text { Deep learning-based multi-phase face } \\
\text { mask detection model }\end{array}$ & TCCE & 2020 \\
\hline S153 & [182] & $\begin{array}{l}\text { Mobility-guided modeling of the } \\
\text { COVID-19 pandemic in Metro Manila }\end{array}$ & Model to simulate the pandemic & PJS & 2020 \\
\hline S154 & [183] & $\begin{array}{l}\text { Modeling and mining spatiotemporal } \\
\text { patterns of infection risk from } \\
\text { heterogeneous data for active } \\
\text { surveillance planning }\end{array}$ & $\begin{array}{l}\text { Method to active surveillance } \\
\text { planning via modeling and mining } \\
\text { spatiotemporal patterns of infection } \\
\text { risks from heterogeneous } \\
\text { data sources }\end{array}$ & AAAI & 2014 \\
\hline S155 & [184] & $\begin{array}{l}\text { Modeling Individual-Level Infection } \\
\text { Dynamics Using Social Network } \\
\text { Information }\end{array}$ & $\begin{array}{c}\text { Non-invasive } \\
\text { disease monitoring system that } \\
\text { accurately identifies the specific } \\
\text { people who are sick, without } \\
\text { explicitly diagnosing them }\end{array}$ & CIKM & 2015 \\
\hline S156 & [185] & $\begin{array}{l}\text { Modelling the response of a public health } \\
\text { department to infectious disease }\end{array}$ & $\begin{array}{l}\text { Discrete-event simulation model of } \\
\text { the response of a local public health } \\
\text { department to pertussis cases }\end{array}$ & WSC & 2010 \\
\hline S157 & [186] & $\begin{array}{l}\text { Monitoring health care workers at risk for } \\
\text { COVID-19 using wearable sensors and } \\
\text { smartphone technology: Protocol for an } \\
\text { observational mHealth study }\end{array}$ & $\begin{array}{l}\text { Physiological data monitoring of } \\
\text { healthcare workers }\end{array}$ & JMIR & 2021 \\
\hline S158 & [187] & $\begin{array}{c}\text { Multilingual COVID-QA: Learning } \\
\text { towards Global Information Sharing via } \\
\text { Web Question Answering in } \\
\text { Multiple Languages }\end{array}$ & $\begin{array}{l}\text { Multilingual COVID-QA } \\
\text { model to answer people's questions } \\
\text { in their own languages }\end{array}$ & $\begin{array}{l}\text { WWW } \\
\text { Companion }\end{array}$ & 2021 \\
\hline S159 & [188] & $\begin{array}{l}\text { NanoSPC: A scalable, portable, cloud } \\
\text { compatible viral nanopore metagenomic } \\
\text { data processing pipeline }\end{array}$ & $\begin{array}{l}\text { Pipeline for analyzing Nanopore } \\
\text { sequencing data to identify } \\
\text { potentially pathogenic viruses } \\
\text { and bacteria }\end{array}$ & NAR & 2020 \\
\hline S160 & [189] & $\begin{array}{l}\text { On calibrating a microsimulation of patient } \\
\text { movement through a healthcare network }\end{array}$ & $\begin{array}{l}\text { Microsimulation to simulate } \\
\text { pathogen transmission among } \\
\text { individuals }\end{array}$ & WSC & 2019 \\
\hline S161 & [190] & $\begin{array}{l}\text { Optimal control strategy for a } \\
\text { multi-regional epidemic model }\end{array}$ & $\begin{array}{l}\text { Multi-regional model for the global } \\
\text { spread of an emerging and } \\
\text { re-emerging infectious disease }\end{array}$ & WCICA & 2012 \\
\hline S162 & [191] & $\begin{array}{c}\text { P2B-Trace: Privacy-Preserving } \\
\text { Blockchain-based Contact Tracing to } \\
\text { Combat Pandemics }\end{array}$ & $\begin{array}{c}\text { P2B-Trace, a privacy-preserving } \\
\text { contact tracing initiative based } \\
\text { on blockchain }\end{array}$ & SIGMOD & 2021 \\
\hline S163 & [192] & Pandemic Stabilizer using Smartwatch & $\begin{array}{l}\text { Smartwatch adoption to screen } \\
\text { individuals for body temperature, } \\
\text { heart rate and blood pressure }\end{array}$ & DASA & 2020 \\
\hline S164 & [193] & $\begin{array}{l}\text { Parallel low discrepancy parameter sweep } \\
\text { for public health policy }\end{array}$ & $\begin{array}{l}\text { Approach that pre-computes } \\
\text { simulations of passenger movement, } \\
\text { performing only the disease-specific } \\
\text { analysis in real time }\end{array}$ & CCGrid & 2018 \\
\hline
\end{tabular}


Table A1. Cont.

\begin{tabular}{|c|c|c|c|c|c|}
\hline ID & Reference & Title & Approach & $\begin{array}{l}\text { Venue } \\
\text { Acronym }\end{array}$ & Year \\
\hline S165 & [194] & $\begin{array}{l}\text { Participatory disease detection through } \\
\text { digital volunteerism: how the doctorme } \\
\text { application aims to capture data for faster } \\
\text { disease detection in thailand }\end{array}$ & $\begin{array}{l}\text { Disease Detection through Digital } \\
\text { Volunteerism and Mobile } \\
\text { application adoption }\end{array}$ & $\begin{array}{c}\text { WWW } \\
\text { Companion }\end{array}$ & 2014 \\
\hline S166 & [195] & $\begin{array}{c}\text { People Under Surveillance Tracker } \\
\text { Prototype Development with Bluetooth } \\
\text { Low Energy to Suppress the } \\
\text { COVID-19 Spread }\end{array}$ & Mobile-based tracking application & ICORIS & 2020 \\
\hline S167 & [196] & $\begin{array}{c}\text { Physical distancing and risk of COVID-19 } \\
\text { in small-scale fisheries: a remote sensing } \\
\text { assessment in coastal Ghana }\end{array}$ & $\begin{array}{l}\text { Unmanned Aerial Vehicle technology } \\
\text { adoption for policy direction and } \\
\text { intervention in pandemic }\end{array}$ & Sci Rep & 2020 \\
\hline S168 & [197] & $\begin{array}{l}\text { Potential application of novel technology } \\
\text { developed for instant decontamination of } \\
\text { personal protective equipment before the } \\
\text { doffing step }\end{array}$ & $\begin{array}{l}\text { Spray disinfection technology } \\
\text { (chamber) }\end{array}$ & PLoS ONE & 2021 \\
\hline S169 & [198] & $\begin{array}{c}\text { Predicting COVID-19 infections and deaths } \\
\text { in Bangladesh using Machine Learning } \\
\text { Algorithms }\end{array}$ & $\begin{array}{l}\text { Prediction of COVID-19 pandemic } \\
\text { future cases by the adoption and } \\
\text { exploration of machine learning } \\
\text { algorithms }\end{array}$ & ICICT4SD & 2021 \\
\hline S170 & [199] & $\begin{array}{l}\text { Prediction on COVID-19 via Logit Model } \\
\text { for the Five Worst-Affected Countries } \\
\text { in Global }\end{array}$ & $\begin{array}{c}\text { Prediction on COVID-19 spread via } \\
\text { Logit Model }\end{array}$ & CONFCDS & 2021 \\
\hline S171 & [200] & $\begin{array}{l}\text { Prevention from COVID-19 in India: Fuzzy } \\
\text { Logic Approach }\end{array}$ & $\begin{array}{l}\text { Fuzzy Logic approach application to } \\
\text { identify possible infections by } \\
\text { symptom analysis }\end{array}$ & ICACITE & 2021 \\
\hline S172 & [201] & $\begin{array}{c}\text { Privacy-preserving People Counting with } \\
\text { Channel State Information }\end{array}$ & $\begin{array}{l}\text { Method of counting the number of } \\
\text { people in the space }\end{array}$ & ICTC & 2020 \\
\hline S173 & [202] & $\begin{array}{l}\text { Private blockchain-envisioned security } \\
\text { framework for AI-enabled IoT-based } \\
\text { drone-aided healthcare services }\end{array}$ & $\begin{array}{c}\text { Private-blockchain based framework } \\
\text { for secure communication in an } \\
\text { IoT-enabled drone-aided healthcare } \\
\text { environment }\end{array}$ & DroneCom & 2020 \\
\hline S174 & [203] & $\begin{array}{l}\text { Protecting healthcare workers during } \\
\text { COVID-19 pandemic with nanotechnology: } \\
\text { A protocol for a new device from Egypt }\end{array}$ & $\begin{array}{l}\text { Design for antimicrobial and antiviral } \\
\text { respirator facial mask with } \\
\text { nanotechnology }\end{array}$ & $\begin{array}{l}\text { J. Infect. Public } \\
\text { Health }\end{array}$ & 2020 \\
\hline S175 & [204] & $\begin{array}{l}\text { Proximity tracing method to reduce } \\
\text { community spread of COVID } 19\end{array}$ & $\begin{array}{l}\text { Mobile app wherein a user who is } \\
\text { infected or detected with corona } \\
\text { positive can be backward traced }\end{array}$ & JET & 2020 \\
\hline S176 & [205] & $\begin{array}{l}\text { Rapid deployment of a free, } \\
\text { privacy-assured COVID-19 symptom } \\
\text { tracker for public safety during reopening: } \\
\text { System development and feasibility study }\end{array}$ & $\begin{array}{c}\text { Develop a monitoring and reporting } \\
\text { system for COVID-19 to support } \\
\text { institutions conducting monitoring } \\
\text { activities }\end{array}$ & JMIR & 2020 \\
\hline S177 & [206] & $\begin{array}{l}\text { Realization of Temperature Measurement } \\
\text { by Passive Terahertz Imaging }\end{array}$ & $\begin{array}{c}\text { Temperature Measurement by } \\
\text { Passive Terahertz Imaging }\end{array}$ & UCMMT & 2020 \\
\hline S178 & [207] & $\begin{array}{l}\text { Real-time Mask Identification for } \\
\text { COVID-19: An Edge Computing-based } \\
\text { Deep Learning Framework }\end{array}$ & $\begin{array}{l}\text { ECMask-Edge computing-based } \\
\text { mask identification framework }\end{array}$ & $\begin{array}{l}\text { IEEE Internet } \\
\text { Things J }\end{array}$ & 2021 \\
\hline S179 & [208] & $\begin{array}{l}\text { Rebirth-20-Relive After the COVID-19 } \\
\text { and Keep Preventing Against it }\end{array}$ & $\begin{array}{l}\text { Software for teaching gestures and } \\
\text { actions that contribute to the } \\
\text { prevention of COVID and also } \\
\text { provide exercises for recovery after } \\
\text { contracting COVID }\end{array}$ & VRW & 2021 \\
\hline S180 & [209] & $\begin{array}{l}\text { Recommendation rules mining for } \\
\text { reducing the spread of COVID-19 cases }\end{array}$ & $\begin{array}{l}\text { Recommendation rules building for } \\
\text { appropriated state policy for } \\
\text { reducing the spread of new } \\
\text { COVID-19 cases }\end{array}$ & IDDM & 2020 \\
\hline
\end{tabular}


Table A1. Cont.

\begin{tabular}{|c|c|c|c|c|c|}
\hline ID & Reference & Title & Approach & $\begin{array}{l}\text { Venue } \\
\text { Acronym }\end{array}$ & Year \\
\hline S181 & [210] & $\begin{array}{l}\text { Remote sensing of vital signs: A Wearable, } \\
\text { Wireless "band-Aid" sensor with } \\
\text { personalized analytics for improved ebola } \\
\text { patient care and worker safety }\end{array}$ & $\begin{array}{c}\text { Wearable, Wireless "band-Aid" } \\
\text { sensor with personalized analytics for } \\
\text { improved Ebola patient care and } \\
\text { worker safety }\end{array}$ & GHSP & 2015 \\
\hline S182 & [211] & $\begin{array}{c}\text { RFWash: a weakly supervised tracking of } \\
\text { hand hygiene technique }\end{array}$ & $\begin{array}{l}\text { Radio-based device-free system for } \\
\text { monitoring Hand Hygiene technique }\end{array}$ & SenSys & 2020 \\
\hline S183 & [212] & $\begin{array}{l}\text { Role of 5G-powered remote robotic } \\
\text { ultrasound during the COVID-19 outbreak: } \\
\text { Insights from two cases }\end{array}$ & $\begin{array}{l}\text { Robotic ultrasound based on } \\
\text { 5G-powered technology adoption }\end{array}$ & $\begin{array}{l}\text { Eur Rev Med } \\
\text { Pharmacol Sci }\end{array}$ & 2020 \\
\hline S184 & [213] & SD-Measure: A Social Distancing Detector & $\begin{array}{l}\text { Novel framework for detecting social } \\
\text { distancing from video footages }\end{array}$ & $\mathrm{CICN}$ & 2020 \\
\hline S185 & [214] & $\begin{array}{c}\text { Secured College Bus Management System } \\
\text { using IoT for COVID-19 Pandemic } \\
\text { Situation }\end{array}$ & $\begin{array}{l}\text { Secured College Bus Management } \\
\text { System (SCBMS) for student } \\
\text { screening and mask detection }\end{array}$ & ICICV & 2021 \\
\hline S186 & [215] & $\begin{array}{c}\text { Security Control Components for Epidemic } \\
\text { Prevention Donation Management } \\
\text { Blockchain }\end{array}$ & $\begin{array}{c}\text { Blockchain adoption in order to } \\
\text { improve security in information } \\
\text { control of donations management in } \\
\text { pandemic scenarios }\end{array}$ & BSCI & 2020 \\
\hline S187 & [216] & $\begin{array}{c}\text { Seeing is Comforting: Effects of } \\
\text { Teleoperator Visibility in Robot-Mediated } \\
\text { Health Care }\end{array}$ & $\begin{array}{l}\text { Robot teleoperator adoption in } \\
\text { patients' medical care }\end{array}$ & HRI & 2016 \\
\hline S188 & [217] & $\begin{array}{l}\text { Simulating the Evolution of Infectious } \\
\text { Agents Through Human Interaction }\end{array}$ & $\begin{array}{l}\text { Software simulation method for } \\
\text { spread prevention }\end{array}$ & SIITME & 2020 \\
\hline S189 & [218] & $\begin{array}{l}\text { Simulation Analysis of Epidemic Trend for } \\
\text { COVID-19 Based on SEIRS Model }\end{array}$ & $\begin{array}{l}\text { Model to simulate and forecast the } \\
\text { trend of COVID-19 epidemic }\end{array}$ & $\mathrm{ICCI}^{*} \mathrm{CC}$ & 2020 \\
\hline S190 & [219] & $\begin{array}{l}\text { Simulation of strategies for containing } \\
\text { pandemic influenza }\end{array}$ & $\begin{array}{l}\text { Stochastic simulation model of } \\
\text { pandemic influenza to investigate } \\
\text { realistic intervention strategies in } \\
\text { reaction to developing outbreaks }\end{array}$ & WSC & 2010 \\
\hline S191 & [220] & $\begin{array}{l}\text { Smart epidemic tunnel: IoT-based } \\
\text { sensor-fusion assistive technology for } \\
\text { COVID-19 disinfection }\end{array}$ & $\begin{array}{l}\text { IoT-based sensor-fusion assistive } \\
\text { technology for COVID-19 disinfection }\end{array}$ & IJPCC & 2020 \\
\hline S192 & [221] & $\begin{array}{l}\text { Smart homes that detect sneeze, cough, } \\
\text { and face touching }\end{array}$ & $\begin{array}{c}\text { Smart home monitoring system to } \\
\text { detect coughing, sneezing, face } \\
\text { touching, and } \\
\text { entering/leaving a room }\end{array}$ & Smart Health & 2021 \\
\hline S193 & [222] & $\begin{array}{l}\text { SmartGate system: Automating the } \\
\text { detection and control of COVID-19 }\end{array}$ & $\begin{array}{l}\text { SmartGate to detect the potential of } \\
\text { the virus in patients without human } \\
\text { intervention }\end{array}$ & ICFNDS & 2020 \\
\hline S194 & [223] & $\begin{array}{l}\text { Social Distancing using Bluetooth Low } \\
\text { Energy to Prevent the Spread of COVID-19 }\end{array}$ & $\begin{array}{c}\text { Development of an Android } \\
\text { Application for Social Distancing } \\
\text { Alert System }\end{array}$ & Confluence & 2021 \\
\hline S195 & [224] & $\begin{array}{l}\text { Social distancing warning system at public } \\
\text { transportation by analyzing wi-fi signal } \\
\text { from mobile devices }\end{array}$ & Social distancing warning system & ISWC & 2020 \\
\hline S196 & [225] & $\begin{array}{l}\text { SociTrack: infrastructure-free interaction } \\
\text { tracking through mobile sensor networks }\end{array}$ & $\begin{array}{l}\text { Platform for autonomous social } \\
\text { interaction tracking via wireless } \\
\text { distance measurements }\end{array}$ & MobiCom & 2020 \\
\hline S197 & [226] & $\begin{array}{c}\text { Solar Power based Intelligent System for } \\
\text { Hand wash cum Dryer to Conflict the } \\
\text { Outbreak of COVID-19 }\end{array}$ & $\begin{array}{l}\text { Solar Powered automatic hand } \\
\text { dryer system }\end{array}$ & ICISS & 2020 \\
\hline S198 & [227] & $\begin{array}{l}\text { Sonography of the Lungs: Diagnosis and } \\
\text { Surveillance of Patients with COVID-19 }\end{array}$ & $\begin{array}{l}\text { Use of sonography to evaluate the } \\
\text { lungs for COVID-19 infection } \\
\text { identification }\end{array}$ & JDMS & 2020 \\
\hline S199 & [228] & $\begin{array}{c}\text { System design of safety road network in } \\
\text { urban morphology prevention during } \\
\text { COVID-19 based on digital simulation } \\
\text { technology }\end{array}$ & $\begin{array}{l}\text { System design of public } \\
\text { transportation, prevention, and } \\
\text { control of urban pandemics }\end{array}$ & $\mathrm{BDE}$ & 2020 \\
\hline
\end{tabular}


Table A1. Cont.

\begin{tabular}{|c|c|c|c|c|c|}
\hline ID & Reference & Title & Approach & $\begin{array}{l}\text { Venue } \\
\text { Acronym }\end{array}$ & Year \\
\hline S200 & [229] & $\begin{array}{l}\text { Targeted Vaccination for COVID-19 Using } \\
\text { Mobile Communication Networks }\end{array}$ & $\begin{array}{l}\text { Targeted vaccination mathematical } \\
\text { method to allocate a limited number } \\
\text { of vaccines }\end{array}$ & IKT & 2020 \\
\hline S201 & [230] & $\begin{array}{l}\text { TDEFSI: Theory-guided Deep } \\
\text { Learning-based Epidemic Forecasting with } \\
\text { Synthetic Information }\end{array}$ & $\begin{array}{l}\text { Theory-guided Deep Learning-based } \\
\text { Epidemic Forecasting }\end{array}$ & TSAS & 2020 \\
\hline S202 & [231] & $\begin{array}{l}\text { Telehealth mask wearing training for } \\
\text { children with autism during the } \\
\text { COVID-19 pandemic }\end{array}$ & $\begin{array}{l}\text { Telehealth mask wearing training for } \\
\text { children with autism }\end{array}$ & $\begin{array}{l}\text { J. Appl. Behav. } \\
\text { Anal. }\end{array}$ & 2021 \\
\hline S203 & [232] & $\begin{array}{l}\text { The Application of Mobile Telehealth } \\
\text { System to Facilitate Patient Information } \\
\text { Presentation and Case Discussion }\end{array}$ & $\begin{array}{l}\text { Mobile Telehealth System to Facilitate } \\
\text { Patient Information Presentation and } \\
\text { Case Discussion }\end{array}$ & $\begin{array}{l}\text { Telemed } \\
\text { E-Health }\end{array}$ & 2020 \\
\hline S204 & [233] & $\begin{array}{c}\text { The development of the geographical } \\
\text { information system (GIS)-based mapping } \\
\text { of infectious diseases using spatial } \\
\text { data analysis }\end{array}$ & $\begin{array}{l}\text { Web-based Decision Support System } \\
\text { with Android Mobile Support, } \\
\text { Mapping and Short Message Service } \\
\text { development and adoption }\end{array}$ & IJATCSE & 2019 \\
\hline S205 & [234] & $\begin{array}{l}\text { The effectiveness of disinfectant spraying } \\
\text { based on drone technology }\end{array}$ & $\begin{array}{l}\text { Disinfectant spraying application and } \\
\text { testing based on drone technology }\end{array}$ & EIC & 2020 \\
\hline S206 & [235] & $\begin{array}{l}\text { The Impact of Histogram Equalization and } \\
\text { Color Mapping on ResNet-34's Overall } \\
\text { Performance for COVID-19 Detection }\end{array}$ & $\begin{array}{l}\text { Methodology to assess the overall } \\
\text { performance of a deep CNN } \\
\text { architecture for COVID-19 detection }\end{array}$ & DSDE & 2021 \\
\hline S207 & [236] & $\begin{array}{c}\text { The Implementation of an Emergency } \\
\text { Medicine Telehealth System during } \\
\text { a Pandemic }\end{array}$ & $\begin{array}{l}\text { Emergency medicine telehealth } \\
\text { system implementation }\end{array}$ & JEM & 2021 \\
\hline S208 & [237] & $\begin{array}{l}\text { The picture of health: map-based, } \\
\text { collaborative spatio-temporal } \\
\text { disease tracking }\end{array}$ & $\begin{array}{l}\text { System adoption for disease detection } \\
\text { and tracking by geotagging } \\
\text { ProMED-mail postings }\end{array}$ & HealthGIS & 2012 \\
\hline S209 & [238] & $\begin{array}{c}\text { The study of colleges students returning to } \\
\text { campus under the epidemic situation } \\
\text { based on GIS }\end{array}$ & $\begin{array}{l}\text { Formulate a strategy for } \\
\text { college students returning to campus } \\
\text { in batches after the epidemic }\end{array}$ & EMGIS & 2020 \\
\hline S210 & [239] & $\begin{array}{c}\text { To quarantine, or not to quarantine: } \\
\text { A theoretical framework for disease control } \\
\text { via contact tracing }\end{array}$ & $\begin{array}{l}\text { Compartmental model for COVID19 } \\
\text { disease progression, in a modeling } \\
\text { framework that captures testing } \\
\text { and digital contact tracing }\end{array}$ & Epidemics & 2021 \\
\hline S211 & [240] & $\begin{array}{l}\text { Toward optimal resource-allocation for } \\
\text { control of epidemics: an } \\
\text { agent-based-simulation approach }\end{array}$ & $\begin{array}{l}\text { Agent-based simulation model } \\
\text { of epidemics }\end{array}$ & WSC & 2010 \\
\hline S212 & [241] & $\begin{array}{l}\text { Tracking and visualization of space-time } \\
\text { activities for a micro-scale flu } \\
\text { transmission study }\end{array}$ & $\begin{array}{l}\text { Use of tracking devices to collect data } \\
\text { of space-time trajectories and the } \\
\text { spatiotemporal processing of such } \\
\text { data to facilitate flu } \\
\text { transmission study }\end{array}$ & IJHG & 2013 \\
\hline S213 & [242] & $\begin{array}{l}\text { Tracking Urban Mobility and Occupancy } \\
\text { under Social Distancing Policy }\end{array}$ & $\begin{array}{l}\text { Multi-scale map of urban mobility } \\
\text { and space occupancy under social } \\
\text { distancing policy }\end{array}$ & DGOV & 2020 \\
\hline S214 & [243] & $\begin{array}{l}\text { Tracy: Smartphone-based Contact Tracing } \\
\text { Solution that Supports Self-investigation to } \\
\text { Limit the Spread of COVID-19 }\end{array}$ & $\begin{array}{c}\text { innovative privacy preserving } \\
\text { smartphone-based contact tracing } \\
\text { solution }\end{array}$ & NILES & 2020 \\
\hline S215 & [244] & $\begin{array}{c}\text { Two Approximate Dynamic Programming } \\
\text { Algorithms for Managing Complete } \\
\text { SIS Networks }\end{array}$ & $\begin{array}{l}\text { Dynamic Programming Algorithms } \\
\text { for Managing Complete SIS } \\
\text { Networks inspired by the case study } \\
\text { of mosquito Aedes albopictus }\end{array}$ & COMPASS & 2018 \\
\hline S216 & [245] & $\begin{array}{c}\text { Understanding the Urban Pandemic } \\
\text { Spreading of COVID-19 with Real World } \\
\text { Mobility Data }\end{array}$ & $\begin{array}{l}\text { Data-driven epidemic simulator with } \\
\text { COVID-19 specific features }\end{array}$ & KDD & 2020 \\
\hline
\end{tabular}


Table A1. Cont.

\begin{tabular}{|c|c|c|c|c|c|}
\hline ID & Reference & Title & Approach & $\begin{array}{c}\text { Venue } \\
\text { Acronym }\end{array}$ & Year \\
\hline S217 & [246] & $\begin{array}{c}\text { Using a sharing-platform to prevent a new } \\
\text { outbreak of COVID-19 pandemic in } \\
\text { rural areas }\end{array}$ & $\begin{array}{c}\text { Develop an exchange platform to } \\
\text { track the spread of COVID-19 in } \\
\text { rural areas }\end{array}$ & GJESM & 2021 \\
\hline S218 & [247] & $\begin{array}{l}\text { Using machine vision for functionality } \\
\text { expansion of mini robots decontaminating } \\
\text { medical personnel premises in conditions } \\
\text { of COVID-19 epidemic }\end{array}$ & $\begin{array}{l}\text { Mobile autonomous robots' adoption } \\
\text { to reduce risks of infections of } \\
\text { medical personnel }\end{array}$ & ISPRS Archives & 2021 \\
\hline S219 & [248] & $\begin{array}{l}\text { Wireless applications for hospital } \\
\text { epidemiology }\end{array}$ & $\begin{array}{l}\text { Low-cost wireless system to } \\
\text { instrument hand-hygiene events }\end{array}$ & WiMD & 2019 \\
\hline
\end{tabular}

Table A2. Mapping of studies regarding digital libraries.

\begin{tabular}{|c|c|c|c|c|c|c|c|c|c|c|c|c|c|c|c|c|c|c|c|}
\hline ID & $\mathrm{ACM}$ & IEEE & $\begin{array}{l}\text { Scop- } \\
\text { us }\end{array}$ & $\begin{array}{l}\text { Comp- } \\
\text { endex }\end{array}$ & ID & $\mathrm{ACM}$ & IEEE & $\begin{array}{l}\text { Scop- } \\
\text { us }\end{array}$ & $\begin{array}{l}\text { Comp- } \\
\text { endex }\end{array}$ & ID & ACM & IEEE & $\begin{array}{l}\text { Scop- } \\
\text { us }\end{array}$ & $\begin{array}{l}\text { Comp- } \\
\text { endex }\end{array}$ & ID & $\mathrm{ACM}$ & IEEE & $\begin{array}{l}\text { Scop- } \\
\text { us }\end{array}$ & $\begin{array}{l}\text { Comp- } \\
\text { endex }\end{array}$ \\
\hline S1 & $x$ & & & & S56 & & & $x$ & $x$ & S111 & & $x$ & & & S166 & & $x$ & & \\
\hline S2 & $X$ & & & & S57 & & $x$ & & & S112 & $X$ & & & & S167 & & & $x$ & \\
\hline S3 & & $x$ & $X$ & $X$ & S58 & & $X$ & & & S113 & & & $X$ & & S168 & & & $X$ & \\
\hline S4 & $X$ & & & & S59 & $X$ & & & & S114 & $X$ & & & & S169 & & $X$ & & \\
\hline S5 & $x$ & $X$ & & & S60 & $X$ & & & & S115 & & $X$ & $X$ & $X$ & S170 & $X$ & & & \\
\hline S6 & & $X$ & & & S61 & & $X$ & & & S116 & $X$ & & & & S171 & & $X$ & & \\
\hline S7 & & $x$ & & & S62 & $x$ & & & & S117 & & $X$ & & & S172 & & $X$ & & \\
\hline S8 & $X$ & & & & S63 & & $x$ & & & S118 & & & $X$ & $X$ & S173 & $x$ & & & \\
\hline S9 & $x$ & & & & S64 & $x$ & & & & S119 & $X$ & & & & S174 & & & $X$ & \\
\hline S10 & & $x$ & & & S65 & & $X$ & $X$ & $x$ & S120 & $X$ & & & & S175 & & & $X$ & \\
\hline S11 & & & $X$ & & S66 & $X$ & & & & S121 & $x$ & & & & S176 & & & $x$ & \\
\hline $\mathrm{S} 12$ & & $x$ & $X$ & $X$ & S67 & & $X$ & $X$ & $X$ & S122 & & $X$ & & & S177 & & $X$ & $X$ & $x$ \\
\hline $\mathrm{S} 13$ & & & $x$ & & S68 & & $X$ & $x$ & $X$ & $\mathrm{~S} 123$ & & $X$ & $X$ & & S178 & & $x$ & & \\
\hline S14 & $X$ & & & & S69 & & & $x$ & $X$ & S124 & & $X$ & $X$ & $X$ & S179 & & $x$ & & \\
\hline S15 & & $X$ & & & S70 & $X$ & & & & S125 & & $X$ & & & S180 & & & $X$ & \\
\hline S16 & & $x$ & $X$ & & S71 & & $X$ & $X$ & $X$ & S126 & $X$ & & & & S181 & & & $X$ & \\
\hline S17 & $x$ & $x$ & & & S72 & & & $X$ & $X$ & S127 & & $X$ & & & S182 & $x$ & & & \\
\hline S18 & $x$ & & & & S73 & & $x$ & & & S128 & & $X$ & & & S183 & & & $x$ & \\
\hline S19 & $x$ & & & & S74 & & & $X$ & $X$ & S129 & & $X$ & & & S184 & & $X$ & & \\
\hline S20 & & $x$ & & & S75 & & $X$ & & & S130 & $X$ & & & & S185 & & $x$ & & \\
\hline S21 & & $x$ & & & S76 & $X$ & & & & S131 & & & & $X$ & S186 & $X$ & & & \\
\hline S22 & & $X$ & & & S77 & & & $X$ & & S132 & $X$ & & & & S187 & $x$ & $X$ & & \\
\hline $\mathrm{S} 23$ & $x$ & & & & S78 & & & $X$ & & $\mathrm{~S} 133$ & & $X$ & $X$ & $X$ & S188 & & $X$ & & \\
\hline S24 & & & $X$ & & S79 & & $x$ & $X$ & & $\mathrm{~S} 134$ & & $X$ & $X$ & $X$ & S189 & & $X$ & & \\
\hline S25 & & & $X$ & & S80 & & & $X$ & $X$ & S135 & & & $X$ & & S190 & $X$ & & & \\
\hline S26 & & & $X$ & $x$ & S81 & $X$ & & & & S136 & & & $X$ & $X$ & S191 & & & $X$ & \\
\hline S27 & & & $X$ & & S82 & & $X$ & & & S137 & & $X$ & & & S192 & & & $X$ & \\
\hline S28 & $x$ & & & & S83 & $X$ & & & & S138 & $X$ & & & & S193 & $X$ & & $X$ & \\
\hline S29 & $x$ & & & & S84 & & & $X$ & $X$ & S139 & & & $X$ & & S194 & & $X$ & $x$ & $x$ \\
\hline S30 & & $x$ & & & S85 & $x$ & & & & S140 & $X$ & & & & S195 & $x$ & & & \\
\hline S31 & & $x$ & & & S86 & & & $X$ & & S141 & $x$ & & $X$ & & S196 & $X$ & & & \\
\hline S32 & & $x$ & & & S87 & & $X$ & $X$ & & S142 & & & $X$ & $X$ & S197 & & $x$ & $X$ & \\
\hline S33 & $X$ & & & & S88 & & $x$ & $X$ & $X$ & S143 & & $X$ & & & S198 & & & $X$ & \\
\hline S34 & & & $X$ & $X$ & S89 & & & $X$ & & S144 & & $X$ & & & S199 & $X$ & & $X$ & $X$ \\
\hline S35 & & & & $X$ & S90 & $X$ & & & & S145 & $X$ & & & & S200 & & $X$ & & \\
\hline S36 & $X$ & & & & S91 & $x$ & $X$ & & & S146 & $X$ & & & & S201 & $X$ & & & \\
\hline S37 & $X$ & & & & S92 & & $x$ & $X$ & $X$ & S147 & $X$ & & & & $\mathrm{~S} 202$ & & & $X$ & \\
\hline S38 & & $x$ & & & S93 & & & $X$ & & S148 & & & $X$ & & S203 & & & $x$ & $X$ \\
\hline S39 & & & $X$ & & S94 & & & $X$ & & S149 & & $X$ & & & S204 & & & $x$ & \\
\hline S40 & $x$ & & & & S95 & & & $X$ & & S150 & $X$ & & & & S205 & & & $X$ & $x$ \\
\hline S41 & $x$ & & & & S96 & $X$ & $x$ & & & S151 & $x$ & & & & S206 & $X$ & & & \\
\hline S42 & & & $X$ & & S97 & & $x$ & & & S152 & & & $x$ & $X$ & S207 & & & $X$ & \\
\hline S43 & $x$ & & & & S98 & & $X$ & & & S153 & & & $x$ & & S208 & $x$ & & & \\
\hline S44 & $x$ & & & & S99 & $x$ & & & & S154 & $X$ & & & $X$ & S209 & $X$ & & & \\
\hline S45 & & & $X$ & & S100 & $X$ & & & & S155 & $X$ & & & & S210 & & & $X$ & \\
\hline S46 & $X$ & & & & S101 & & $X$ & & & S156 & $X$ & & & & S211 & $X$ & & & \\
\hline S47 & & $x$ & $X$ & $x$ & $\mathrm{~S} 102$ & $X$ & X & & & S157 & & & $X$ & & S212 & & & $X$ & \\
\hline $\mathrm{S} 48$ & $X$ & & & & $\mathrm{~S} 103$ & $X$ & $x$ & & & S158 & $X$ & & & & S213 & $x$ & & & \\
\hline S49 & & $x$ & $X$ & $X$ & S104 & $X$ & & & & S159 & & & $X$ & & S214 & & $X$ & $X$ & \\
\hline S50 & & & $X$ & $X$ & S105 & $X$ & & & & S160 & $X$ & $X$ & & & S215 & $X$ & & & \\
\hline S51 & & & $X$ & & S106 & & $X$ & & & S161 & & $X$ & & & S216 & $X$ & & & \\
\hline S52 & & $x$ & & & S107 & & $X$ & & & S162 & $x$ & & & & S217 & & & $x$ & \\
\hline S53 & $x$ & & & & S108 & & & $x$ & $X$ & S163 & & $X$ & $X$ & & S218 & & & $x$ & \\
\hline S54 & & & $X$ & & S109 & & $x$ & & & S164 & $X$ & $X$ & & & S219 & $x$ & & & \\
\hline S55 & & $X$ & & & S110 & & & $X$ & & S165 & $X$ & & & & & & & & \\
\hline
\end{tabular}


Table A3. Distribution of selected papers on publication venues.

\begin{tabular}{|c|c|c|c|c|c|c|c|c|c|c|c|}
\hline $\begin{array}{l}\text { Publication } \\
\text { Venue }\end{array}$ & $\#$ & $\%$ & $\begin{array}{l}\text { Publication } \\
\text { Venue }\end{array}$ & $\#$ & $\%$ & $\begin{array}{c}\text { Publication } \\
\text { Venue }\end{array}$ & $\#$ & $\%$ & $\begin{array}{l}\text { Publication } \\
\text { Venue }\end{array}$ & $\#$ & $\%$ \\
\hline WSC & 10 & 4.57 & $\mathrm{CICN}$ & 1 & 0.46 & ICCTIDE & 1 & 0.46 & JEM & 1 & 0.46 \\
\hline JMIR & 4 & 1.82 & CICT & 1 & 0.46 & ICECCE & 1 & 0.46 & JET & 1 & 0.46 \\
\hline KDD & 4 & 1.82 & CiSt & 1 & 0.46 & ICICT & 1 & 0.46 & JGE & 1 & 0.46 \\
\hline $\begin{array}{c}\text { WWW } \\
\text { Companion }\end{array}$ & 4 & 1.82 & CoCoNet & 1 & 0.46 & ICICV & 1 & 0.46 & JIDC & 1 & 0.46 \\
\hline CONFCDS & 3 & 1.37 & COMPASS & 1 & 0.46 & ICIIBMS & 1 & 0.46 & $\begin{array}{l}\text { Methods Inf. } \\
\text { Med. }\end{array}$ & 1 & 0.46 \\
\hline IEEE Access & 3 & 1.37 & Confluence & 1 & 0.46 & ICISA & 1 & 0.46 & $\begin{array}{c}\text { Mob. Netw. } \\
\text { Appl. }\end{array}$ & 1 & 0.46 \\
\hline $\begin{array}{c}\text { IEEE Internet } \\
\text { Things J. }\end{array}$ & 3 & 1.37 & CSBio & 1 & 0.46 & ICISS & 1 & 0.46 & Mobidata & 1 & 0.46 \\
\hline SIGSPATIAL & 3 & 1.37 & CSCI & 1 & 0.46 & ICITSI & 1 & 0.46 & MobiWac & 1 & 0.46 \\
\hline ISWC & 2 & 0.91 & CVIDL & 1 & 0.46 & ICMSP & 1 & 0.46 & $\begin{array}{l}\text { Multimed } \\
\text { Tools Appl }\end{array}$ & 1 & 0.46 \\
\hline ICMHI & 2 & 0.91 & DASA & 1 & 0.46 & ICPECTS & 1 & 0.46 & NAR & 1 & 0.46 \\
\hline CIKM & 2 & 0.91 & DATA & 1 & 0.46 & ICPS & 1 & 0.46 & $\begin{array}{c}\text { Nat. } \\
\text { Commun. }\end{array}$ & 1 & 0.46 \\
\hline DG.O & 2 & 0.91 & DEST & 1 & 0.46 & ICRAI & 1 & 0.46 & $\begin{array}{l}\text { NILES } \\
\text { Pers. }\end{array}$ & 1 & 0.46 \\
\hline DGOV & 2 & 0.91 & $\mathrm{DH}$ & 1 & 0.46 & ICSIM & 1 & 0.46 & $\begin{array}{l}\text { Ubiquitous } \\
\text { Comput. }\end{array}$ & 1 & 0.46 \\
\hline EIC & 2 & 0.91 & DIS & 1 & 0.46 & ICTC & 1 & 0.46 & PJS & 1 & 0.46 \\
\hline Healthcom & 2 & 0.91 & DroneCom & 1 & 0.46 & ICUIMC & 1 & 0.46 & $\begin{array}{c}\text { PLoS ONE } \\
\text { Quant }\end{array}$ & 1 & 0.46 \\
\hline ICAIS & 2 & 0.91 & DSAI & 1 & 0.46 & IDDM & 1 & 0.46 & $\begin{array}{l}\text { Imaging Med } \\
\text { Surg }\end{array}$ & 1 & 0.46 \\
\hline ICCCS & 2 & 0.91 & DSDE & 1 & 0.46 & $\begin{array}{l}\text { IEEE J } \\
\text { Biomed } \\
\text { Health } \\
\text { Inform }\end{array}$ & 1 & 0.46 & R10-HTC & 1 & 0.46 \\
\hline ICFNDS & 2 & 0.91 & DSIT & 1 & 0.46 & $\begin{array}{l}\text { IEEE Trans } \\
\text { Cybern }\end{array}$ & 1 & 0.46 & SC & 1 & 0.46 \\
\hline ICICT4SD & 2 & 0.91 & EATIS & 1 & 0.46 & $\begin{array}{l}\text { IEEE Trans } \\
\text { Fuzzy Syst }\end{array}$ & 1 & 0.46 & SCA & 1 & 0.46 \\
\hline ICOEI & 2 & 0.91 & EITCE & 1 & 0.46 & $\begin{array}{l}\text { IEEE Trans. } \\
\text { Big Data }\end{array}$ & 1 & 0.46 & Sci Rep & 1 & 0.46 \\
\hline ICORIS & 2 & 0.91 & EMGIS & 1 & 0.46 & $\begin{array}{c}\text { IEEE Trans. } \\
\text { Comput. Soc. } \\
\text { Syst. }\end{array}$ & 1 & 0.46 & $\begin{array}{l}\text { SEEDA- } \\
\text { CECNSM }\end{array}$ & 1 & 0.46 \\
\hline IJPCC & 2 & 0.91 & EMBS & 1 & 0.46 & IJACSA & 1 & 0.46 & $\begin{array}{c}\text { Sens. } \\
\text { Actuators }\end{array}$ & 1 & 0.46 \\
\hline MobiCom & 2 & 0.91 & $\begin{array}{c}\text { Epidemics } \\
\text { Eur Rev Med }\end{array}$ & 1 & 0.46 & IJATCSE & 1 & 0.46 & SIGIR & 1 & 0.46 \\
\hline SenSys & 2 & 0.91 & $\begin{array}{l}\text { Pharmacol } \\
\text { Sci }\end{array}$ & 1 & 0.46 & IJCRR & 1 & 0.46 & SIGMOD & 1 & 0.46 \\
\hline SoICT & 2 & 0.91 & $\begin{array}{c}\text { Front. Robot. } \\
\text { AI }\end{array}$ & 1 & 0.46 & IJDSN & 1 & 0.46 & SIITME & 1 & 0.46 \\
\hline WebSci & 1 & 0.46 & FRUCT & 1 & 0.46 & IJERPH & 1 & 0.46 & Smart Health & 1 & 0.46 \\
\hline AAAI & 1 & 0.46 & GCAIoT & 1 & 0.46 & IJHG & 1 & 0.46 & $\begin{array}{l}\text { Socio-Econ. } \\
\text { Plan. Sci. }\end{array}$ & 1 & 0.46 \\
\hline Appl. Sci. & 1 & 0.46 & GHSP & 1 & 0.46 & IJID & 1 & 0.46 & $\begin{array}{l}\text { SSLChina: } \\
\text { IFWS }\end{array}$ & 1 & 0.46 \\
\hline ACM DEV & 1 & 0.46 & GJESM & 1 & 0.46 & IKT & 1 & 0.46 & TCBB & 1 & 0.46 \\
\hline AfriCHI & 1 & 0.46 & HICSS & 1 & 0.46 & IMWUT & 1 & 0.46 & TCCE & 1 & 0.46 \\
\hline EMBC & 1 & 0.46 & HRI & 1 & 0.46 & INCET & 1 & 0.46 & TCSS & 1 & 0.46 \\
\hline AIID & 1 & 0.46 & ICACCS & 1 & 0.46 & $\begin{array}{c}\text { IoT } \\
\text { Companion }\end{array}$ & 1 & 0.46 & $\begin{array}{l}\text { Telemed } \\
\text { E-Health }\end{array}$ & 1 & 0.46 \\
\hline
\end{tabular}


Table A3. Cont.

\begin{tabular}{|c|c|c|c|c|c|c|c|c|c|c|c|}
\hline $\begin{array}{c}\text { Publication } \\
\text { Venue }\end{array}$ & $\#$ & $\%$ & $\begin{array}{c}\text { Publication } \\
\text { Venue }\end{array}$ & $\#$ & $\%$ & $\begin{array}{l}\text { Publication } \\
\text { Venue }\end{array}$ & $\#$ & $\%$ & $\begin{array}{l}\text { Publication } \\
\text { Venue }\end{array}$ & $\#$ & $\%$ \\
\hline $\begin{array}{c}\text { Arab J } \\
\text { Sci Eng. }\end{array}$ & 1 & 0.46 & ICACIE & 1 & 0.46 & ISCTT & 1 & 0.46 & TEM & 1 & 0.46 \\
\hline ARES & 1 & 0.46 & ICACITE & 1 & 0.46 & $\begin{array}{c}\text { ISPRS } \\
\text { Archives }\end{array}$ & 1 & 0.46 & TMIS & 1 & 0.46 \\
\hline HealthGIS & 1 & 0.46 & ICAICTA & 1 & 0.46 & ISRITI & 1 & 0.46 & TSAS & 1 & 0.46 \\
\hline $\mathrm{BCB}$ & 1 & 0.46 & ICAIMAT & 1 & 0.46 & $\begin{array}{c}\text { J. Appl. } \\
\text { Behav. Anal. }\end{array}$ & 1 & 0.46 & TSSA & 1 & 0.46 \\
\hline $\mathrm{BDE}$ & 1 & 0.46 & ICASIT & 1 & 0.46 & $\begin{array}{l}\text { J. Environ. } \\
\text { Biol. }\end{array}$ & 1 & 0.46 & UCMMT & 1 & 0.46 \\
\hline BigDataService & 1 & 0.46 & ICBDM & 1 & 0.46 & $\begin{array}{c}\text { J. Infect. } \\
\text { Public Health }\end{array}$ & 1 & 0.46 & UEMCON & 1 & 0.46 \\
\hline BSCI & 1 & 0.46 & ICCCI & 1 & 0.46 & $\begin{array}{c}\text { J. Intell. } \\
\text { Fuzzy Syst. }\end{array}$ & 1 & 0.46 & VISIGRAPP & 1 & 0.46 \\
\hline CAADRIA & 1 & 0.46 & ICCE-Taiwan & 1 & 0.46 & J. Ultrasound & 1 & 0.46 & VRW & 1 & 0.46 \\
\hline CCEAI & 1 & 0.46 & ICCI & 1 & 0.46 & JBI & 1 & 0.46 & WCICA & 1 & 0.46 \\
\hline CCGrid & 1 & 0.46 & $\mathrm{ICCI}^{*} \mathrm{CC}$ & 1 & 0.46 & JBSBE & 1 & 0.46 & $\begin{array}{c}\text { WI } \\
\text { Companion }\end{array}$ & 1 & 0.46 \\
\hline CCWC & 1 & 0.46 & ICCMS & 1 & 0.46 & JDMS & 1 & 0.46 & WiMD & 1 & 0.46 \\
\hline CHINZ & 1 & 0.46 & ICCSMT & 1 & 0.46 & JEGH & 1 & 0.46 & WiSPNET & 1 & 0.46 \\
\hline
\end{tabular}

Table A4. Citation counts overview.

\begin{tabular}{|c|c|c|c|c|c|c|c|c|c|c|c|c|c|c|c|c|c|}
\hline ID & $\begin{array}{l}\text { Citation } \\
\text { Count }\end{array}$ & ID & $\begin{array}{l}\text { Citation } \\
\text { Count }\end{array}$ & ID & $\begin{array}{l}\text { Citation } \\
\text { Count }\end{array}$ & ID & $\begin{array}{l}\text { Citation } \\
\text { Count }\end{array}$ & ID & $\begin{array}{l}\text { Citation } \\
\text { Count }\end{array}$ & ID & $\begin{array}{l}\text { Citation } \\
\text { Count }\end{array}$ & ID & $\begin{array}{l}\text { Citation } \\
\text { Count }\end{array}$ & ID & $\begin{array}{l}\text { Citation } \\
\text { Count }\end{array}$ & ID & $\begin{array}{l}\text { Citation } \\
\text { Count }\end{array}$ \\
\hline S102 & 338 & $\mathrm{~S} 12$ & 13 & S210 & 7 & S152 & 3 & S21 & 1 & S215 & & S60 & 0 & S115 & 0 & $\mathrm{~S} 170$ & 0 \\
\hline S5 & 138 & S29 & 13 & S17 & 6 & S153 & 3 & S22 & 1 & $\mathrm{~S} 1$ & 0 & S63 & 0 & S117 & 0 & S171 & 0 \\
\hline S104 & 82 & $\mathrm{~S} 123$ & 13 & S36 & 6 & S160 & 3 & S25 & 1 & S2 & 0 & S65 & 0 & S118 & 0 & S177 & 0 \\
\hline S116 & 64 & $\mathrm{~S} 150$ & 13 & S48 & 6 & S182 & 3 & S30 & 1 & S8 & 0 & S66 & 0 & S119 & 0 & S179 & 0 \\
\hline S101 & 45 & S155 & 13 & S184 & 6 & S183 & 3 & S61 & 1 & $\mathrm{~S} 10$ & 0 & S69 & 0 & S121 & 0 & S186 & 0 \\
\hline S212 & 38 & S165 & 13 & S198 & 6 & S196 & 3 & S68 & 1 & S11 & 0 & S70 & 0 & S122 & 0 & S188 & 0 \\
\hline $\mathrm{S} 114$ & 37 & S49 & 12 & $\mathrm{~S} 28$ & 5 & S7 & 2 & S71 & 1 & S13 & 0 & S72 & 0 & S124 & 0 & S189 & 0 \\
\hline $\mathrm{S} 125$ & 37 & S154 & 12 & S46 & 5 & S34 & 2 & S73 & 1 & S14 & 0 & S74 & 0 & S126 & 0 & S193 & 0 \\
\hline S208 & 28 & S201 & 12 & S96 & 5 & S57 & 2 & S82 & 1 & S16 & 0 & S75 & 0 & S127 & 0 & S194 & 0 \\
\hline $\mathrm{S} 132$ & 27 & S9 & 11 & S96 & 5 & S59 & 2 & S95 & 1 & S24 & 0 & S76 & 0 & S131 & 0 & S195 & 0 \\
\hline $\mathrm{S} 211$ & 22 & S202 & 11 & S134 & 5 & S64 & 2 & S100 & 1 & S27 & 0 & S78 & 0 & S133 & 0 & S197 & 0 \\
\hline S174 & 20 & S19 & 10 & S159 & 5 & S67 & 2 & S110 & 1 & S31 & 0 & S79 & 0 & S135 & 0 & S199 & 0 \\
\hline S187 & 20 & S94 & 10 & S41 & 4 & S77 & 2 & S111 & 1 & S32 & 0 & S80 & 0 & $\mathrm{~S} 138$ & 0 & S200 & 0 \\
\hline S4 & 19 & S167 & 10 & S43 & 4 & S91 & 2 & S129 & 1 & S35 & 0 & S81 & 0 & S140 & 0 & S204 & 0 \\
\hline S151 & 18 & S52 & 9 & S105 & 4 & S103 & 2 & S137 & 1 & S37 & 0 & S83 & 0 & S141 & 0 & S205 & 0 \\
\hline S191 & 18 & $\mathrm{~S} 120$ & 8 & S149 & 4 & S113 & 2 & S139 & 1 & S38 & 0 & S84 & 0 & S142 & 0 & S206 & 0 \\
\hline S26 & 17 & S156 & 8 & S176 & 4 & S136 & 2 & S146 & 1 & S39 & 0 & S88 & 0 & S143 & 0 & S209 & 0 \\
\hline S181 & 17 & S164 & 8 & S190 & 4 & S147 & 2 & S163 & 1 & S42 & 0 & S90 & 0 & S144 & 0 & S217 & 0 \\
\hline $\mathrm{S} 130$ & 16 & S178 & 8 & S216 & 4 & S162 & 2 & S168 & 1 & S45 & 0 & S92 & 0 & S145 & 0 & S218 & 0 \\
\hline S23 & 15 & S51 & 7 & S20 & 3 & S180 & 2 & S172 & 1 & S47 & 0 & S97 & 0 & S148 & 0 & & \\
\hline S40 & 15 & S85 & 7 & S44 & 3 & S185 & 2 & S175 & 1 & S50 & 0 & S98 & 0 & S157 & 0 & & \\
\hline S86 & 15 & S87 & 7 & S58 & 3 & S3 & 1 & S192 & 1 & S53 & 0 & S106 & 0 & S158 & 0 & & \\
\hline S219 & 15 & S99 & 7 & S62 & 3 & S6 & 1 & S207 & 1 & S54 & 0 & S107 & 0 & S161 & 0 & & \\
\hline S33 & 14 & $\mathrm{~S} 128$ & 7 & S89 & 3 & S15 & 1 & S213 & 1 & S55 & 0 & $\mathrm{~S} 109$ & 0 & S166 & 0 & & \\
\hline S203 & 14 & S173 & 7 & S108 & 3 & $\mathrm{~S} 18$ & 1 & S214 & 1 & S56 & 0 & $\mathrm{~S} 112$ & 0 & S169 & 0 & & \\
\hline
\end{tabular}

Table A5. Publications distributed by countries and application domain category.

\begin{tabular}{|c|c|c|c|c|c|c|}
\hline $\begin{array}{l}\text { Countries/ } \\
\text { Categories }\end{array}$ & CD1 & CD2 & CD3 & CD4 & CD5 & CD6 \\
\hline China (48) & $\begin{array}{l}\text { S58, S60, S61, S133, } \\
\text { S158, S183, S203 }\end{array}$ & $\begin{array}{l}\text { S26, S148, } \\
\text { S177, S198 }\end{array}$ & $\begin{array}{l}\text { S6, S8, S76, } \\
\text { S142, S144, } \\
\quad \text { S178 }\end{array}$ & $\begin{array}{l}\text { S15, S17, S32, S41, S45, } \\
\text { S55, S66, S81, S97, S98, } \\
\text { S101, S111, S117, S125, } \\
\text { S129, S130, S145, S146, } \\
\text { S161, S170, S186, S189, } \\
\text { S199, S209, S216 }\end{array}$ & S50 & $\begin{array}{l}\text { S34, S49, } \\
\text { S149, S154, } \\
\quad \text { S162 }\end{array}$ \\
\hline USA (38) & $\begin{array}{l}\text { S4, S93, S123, S137, } \\
\text { S151, S157, S160, S181, } \\
\text { S187, S192, S207, S219 }\end{array}$ & S122 & & $\begin{array}{c}\text { S5, S28, S29, S46, S48, S53, } \\
\text { S62, S71, S99, S102, S116, } \\
\text { S138, S155, S156, S164, } \\
\text { S201, S211 }\end{array}$ & $\begin{array}{l}\text { S16, S69, } \\
\text { S213 }\end{array}$ & $\begin{array}{l}\text { S114, S176, } \\
\text { S196, S208, } \\
\quad \text { S212 }\end{array}$ \\
\hline India (31) & $\begin{array}{c}\text { S11, S27, S31, S37, S38, } \\
\text { S57, S127, S141, } \\
\text { S171, S191 }\end{array}$ & S163 & $\begin{array}{l}\text { S47, S75, S107, } \\
\text { S108, S185 }\end{array}$ & S23, S43, S173, & $\begin{array}{l}\text { S10, S30, } \\
\text { S109, S184, } \\
\text { S194 }\end{array}$ & $\begin{array}{c}\text { S20, S33, S72, } \\
\text { S73, S86, } \\
\text { S134, S175 }\end{array}$ \\
\hline
\end{tabular}


Table A5. Cont.

\begin{tabular}{|c|c|c|c|c|c|c|}
\hline $\begin{array}{l}\text { Countries/ } \\
\text { Categories }\end{array}$ & CD1 & CD2 & CD3 & CD4 & CD5 & CD6 \\
\hline Indonesia (9) & S80, S88, S92, S205 & S82 & S143 & S124 & S90 & S166 \\
\hline Thailand (6) & S39, S64, S112 & & S63 & S165 & S135 & \\
\hline South Korea (6) & & & S121 & S54, S91, S120 & S52, S172 & \\
\hline Italy (5) & S24, S103 & & & S113 & S110 & S94 \\
\hline Bangladesh (5) & & & S152, S106 & S68, S169 & S22 & \\
\hline Canada (5) & S139 & & & S44, S83, S132, & S119 & \\
\hline Taiwan (5) & S21, S59, S126 & S35 & & & & S13 \\
\hline United Kingdom (4) & S104 & S159 & & & S79 & S9 \\
\hline Turkey (4) & S95 & S118 & S74 & & & S136 \\
\hline Australia (4) & S77, S182 & & & S215 & & S12 \\
\hline Brazil (3) & S168 & & & S1, S85 & & \\
\hline France (3) & & & & S2 & S179 & S120 \\
\hline Japan (3) & & S128 & & S3 & S195 & \\
\hline Philippines (3) & & & & S147, S153, S204 & & \\
\hline Singapore (3) & S56 & & & S7, S51 & & \\
\hline Egypt (2) & & & & & S174 & S214 \\
\hline Greece (2) & S70 & & & & & S115 \\
\hline Mexico (2) & S89 & & & S100 & & \\
\hline Pakistan (2) & S14 & & & & & S87 \\
\hline Sweden (2) & & & & S180 & S84 & \\
\hline Vietnam (2) & & & & S36, S105 & & \\
\hline Austria (1) & & & & S96 & & \\
\hline Belgium (1) & S202 & & & & & \\
\hline Denmark (1) & & & & & S131 & \\
\hline Equator (1) & S206 & & & & & \\
\hline Ethiopia (1) & S197 & & & & & \\
\hline Georgia (1) & & & & S190 & & \\
\hline Germany (1) & & & & & S19 & \\
\hline Ghana (1) & & & & & S167 & \\
\hline Honduras (1) & S140 & & & & & \\
\hline $\operatorname{Iran}(1)$ & & & & S200 & & \\
\hline Ireland (1) & $S 40$ & & & & & \\
\hline Malaysia (1) & & & & & & S67 \\
\hline New Zealand (1) & S150 & & & & & \\
\hline Nigeria (1) & & & & & & S18 \\
\hline Oman (1) & S25 & & & & & \\
\hline Romania (1) & & & & S188 & & \\
\hline Russia (1) & S218 & & & & & \\
\hline Saudi Arabia (1) & & S193 & & & & \\
\hline Spain (1) & & & & S78 & & \\
\hline Tanzania (1) & & & & & & S42 \\
\hline Tunisia (1) & & S65 & & & & \\
\hline Ukraine (1) & & & & & & S118 \\
\hline
\end{tabular}




\section{References}

1. Baldominos, A.; Puello, A.; Oğul, H.; Aşuroğlu, T.; Colomo-Palacios, R. Predicting Infections Using Computational Intelligence-A Systematic Review. IEEE Access 2020, 8, 31083-31102. [CrossRef]

2. Zhou, P. A pneumonia outbreak associated with a new coronavirus of probable bat origin. Nature 2020, 579, 270-273. [CrossRef] [PubMed]

3. Kabir, M.T. COVID-19 pandemic: From molecular pathogenesis to potential investigational therapeutics. Front. Cell Dev. Biol. 2020, 8, 616. [CrossRef]

4. Mofijur, M.; Fattah, I.R.; Alam, A.; Islam, A.S.; Ong, H.C.; Rahman, S.A.; Najafi, G.; Ahmed, S.; Uddin, A.; Mahlia, T. Impact of COVID-19 on the social, economic, environmental and energy domains: Lessons learnt from a global pandemic. Sustain. Prod. Consum. 2021, 26, 343-359. [CrossRef]

5. Chowdhury, M.A.; Shuvho, B.A.; Shahid, A.; Haque, A.M.; Kashem, M.A.; Lam, S.S.; Ong, H.C.; Uddin, A.; Mofijur, M. Prospect of biobased antiviral face mask to limit the coronavirus outbreak. Environ. Res. 2021, 192, 110294. [CrossRef]

6. Worldometer. Reported Cases and Deaths by Country, Territory, or Conveyance. Available online: https: / / www.worldometers. info/coronavirus (accessed on 9 August 2021).

7. Worldometer. Reported Coronavirus Worldwide Graphs. Available online: https://www.worldometers.info/coronavirus/ worldwide-graphs/\#case-distribution (accessed on 1 August 2021).

8. University of Puget Sound. Preventing the Spread of Infectious Diseases. Available online: https://www.pugetsound.edu/ student-life/counseling-health-and-wellness/health-topics/preventing-the-spread-of-infec (accessed on 14 April 2021).

9. World Health Organization (WHO). Considerations for Quarantine of Individuals in the Context of Containment for Coronavirus Disease (COVID-19) Interim Guidance. 19 March 2020. Available online: https://apps.who.int/iris/bitstream/handle/10665/33 1497/WHO-2019-nCoV-IHR_Quarantine-2020.2-eng.pdf (accessed on 14 April 2021).

10. Harvard Health Publishing. Preventing the Spread of the Coronavirus: Physical Distancing, Masks, and Other Preventive Measures. Harvard Medical School. 9 April 2021. Available online: https:/ /www.health.harvard.edu/diseases-and-conditions/ preventing-the-spread-of-the-coronavirus (accessed on 14 April 2021).

11. Chen, H.; Yang, B.; Pei, H.; Liu, J. Next Generation Technology for Epidemic Prevention and Control: Data-Driven Contact Tracking. IEEE Access 2019, 7, 2633-2642. [CrossRef]

12. Ahmed, N.; Michelin, R.A.; Xue, W.; Ruj, S.; Malaney, R.; Kanhere, S.S.; Seneviratne, A.; Hu, W.; Janicke, H.; Jha, S.K. A Survey of COVID-19 Contact Tracing Apps. IEEE Access 2020, 8, 134577-134601. [CrossRef]

13. Chowdhury, M.J.M.; Ferdous, M.S.; Biswas, K.; Chowdhury, N.; Muthukkumarasamy, V. COVID-19 Contact Tracing: Challenges and Future Directions. IEEE Access 2020, 8, 225703-225729. [CrossRef]

14. Hsaini, S.; Bihri, H.; Azzouzi, S.; El Hassan Charaf, M. Contact-Tracing Approaches to Fight COVID-19 Pandemic: Limits and Ethical Challenges. In Proceedings of the 2020 IEEE 2nd International Conference on Electronics, Control, Optimization and Computer Science (ICECOCS), Kenitra, Morocco, 2-3 December 2020; pp. 1-5. [CrossRef]

15. Ricci, L.; Maesa, D.D.F.; Favenza, A.; Ferro, E. Blockchains for COVID-19 Contact Tracing and Vaccine Support: A Systematic Review. IEEE Access 2021, 9, 37936-37950. [CrossRef]

16. Chamola, V.; Hassija, V.; Gupta, S.; Goyal, A.; Guizani, M.; Sikdar, B. Disaster and Pandemic Management Using Machine Learning: A Survey. IEEE Internet Things J. 2020. [CrossRef]

17. John, C.C.; Ponnusamy, V.; Krishnan Chandrasekaran, S.; Nandakumar, R. A Survey on Mathematical, Machine Learning and Deep Learning Models for COVID-19 Transmission and Diagnosis. IEEE Rev. Biomed. Eng. 2021. [CrossRef]

18. Sudana, D.; Emanuel, A.W. How Big Data in Health 4.0 Helps Prevent the Spread of Tuberculosis. In Proceedings of the 2019 2nd International Conference on Bioinformatics, Biotechnology and Biomedical Engineering (BioMIC)—Bioinformatics and Biomedical Engineering, Yogyakarta, Indonesia, 12-13 September 2019; pp. 1-6. [CrossRef]

19. Siriyasatien, P.; Chadsuthi, S.; Jampachaisri, K.; Kesorn, K. Dengue Epidemics Prediction: A Survey of the State-of-the-Art Based on Data Science Processes. IEEE Access 2018, 6, 53757-53795. [CrossRef]

20. Ikram, T.; Saeed, A.; Ayn, N.; Tahir, M.A.; Mumtaz, R. A review of the prevalent ICT techniques used for COVID-19 SOP violation detection. In Proceedings of the 2020 IEEE 17th International Conference on Smart Communities: Improving Quality of Life Using ICT, IoT and AI (HONET), Charlotte, NC, USA, 14-16 December 2020; pp. 194-198. [CrossRef]

21. Manavi, S.Y.; Nekkanti, V.; Choudhary, R.S.; Jayapandian, N. Review on Emerging Internet of Things Technologies to Fight the COVID-19. In Proceedings of the 2020 Fifth International Conference on Research in Computational Intelligence and Communication Networks (ICRCICN), Bangalore, India, 26-27 November 2020; pp. 202-208. [CrossRef]

22. Ding, X.-R.; Clifton, D.; Ji, N.; Lovell, N.H.; Bonato, P.; Chen, W.; Yu, X.; Xue, J.; Xiang, T.; Long, X.; et al. Wearable Sensing and Telehealth Technology with Potential Applications in the Coronavirus Pandemic. IEEE Rev. Biomed. Eng. 2021, 14, 48-70. [CrossRef] [PubMed]

23. Gupta, R.; Pal, S.K.; Khattar, A.; Baliyan, K. Technology Applications for Health Safety Decision Making under COVID-19 Pandemic Management. In Proceedings of the 2020 International Conference on Decision Aid Sciences and Application (DASA), Sakheer, Bahrain, 8-9 November 2020; pp. 788-793. [CrossRef]

24. Islam, M.N.; Islam, A.K.M.N. A Systematic Review of the Digital Interventions for Fighting COVID-19: The Bangladesh Perspective. IEEE Access 2020, 8, 114078-118087. [CrossRef] [PubMed] 
25. Whitelaw, S.; Mamas, M.A.; Topol, E.; Van Spall, H.G.C. Applications of digital technology in COVID-19 pandemic planning and response. Lancet Digit. Health 2020, 2, 435-440. [CrossRef]

26. Kitchenham, B.A.; Charters, S. Guidelines for Performing Systematic Literature Reviews in Software Engineering; EBSE Technical Report Version 2.3, EBSE-2017-01; Software Engineering Group, Keele University: Keele, UK; University of Durham: Durham, UK, 2007.

27. Chen, L.; Babar, M.A.; Zhang, H. Towards na evidence-based understanding of electronic data sources. In Proceedings of the 14th International Conference on Evaluation and Assessment in Software Engineering (EASE), Swindon, UK, 12-13 April 2010; pp. 135-138.

28. Chen, L.; Babar, M.A.; Cawley, C. A Status Report on the Evaluation of Variability Management Approaches. In Proceedings of the 13th International Conference on Evaluation and Assessment in Software Engineering, EASE'09, Swindon, UK, 20-21 April 2009; pp. 118-127.

29. Dyba, T.; Dingsoyr, T. Empirical Studies of Agile Software Development: A Systematic Review. Inf. Softw. Technol. 2008, 50, 833-859. [CrossRef]

30. Da Silva, R.D.; de Araújo, J.J.P.; de Paiva, F.P.; Valentim, R.A.D.M.; Coutinho, K.D.; de Paiva, J.C.; Roussanaly, A.; Boyer, A. A Big Data Architecture to a Multiple Purpose in Healthcare Surveillance: The Brazilian Syphilis Case. In Proceedings of the EATIS2020: 10th Euro American Conference on Telematics and Information Systems, Coimbra, Portugal, 13-15 May 2020; ACM: New York, NY, USA, 2020; pp. 1-6. [CrossRef]

31. Le, X.T.; Bui, M.; Cohen, J.M. A computational paradigm for the simulation of complex epidemic diseases. In Proceedings of the Seventh Symposium on Information and Communication Technology (SoICT '16), Ho Chi Minh City, Vietnam, 8-9 December 2016; Association for Computing Machinery: New York, NY, USA, 2016; pp. 36-43. [CrossRef]

32. Takemura, T.; Ashida, N.; Makimoto, K.; Kirikae, T.; Okamoto, K.; Kuroda, T.; Nagase, K.; Yoshihara, H. A development of an efficient information collecting and retrieval system using an agent technology-For infectious disease. In Proceedings of the 7th International Workshop on Enterprise Networking and Computing in Healthcare Industry (HEALTHCOM 2005), Busan, Korea, 23-25 June 2005; pp. 456-459. [CrossRef]

33. Barnes, S.; Golden, B.; Wasil, E. A dynamic patient network model of hospital-acquired infections. In Proceedings of the Winter Simulation Conference (WSC '10), Baltimore, MD, USA, 5-8 December 2010; pp. 2249-2260.

34. Bobashev, G.V.; Goedecke, D.M.; Yu, F.; Epstein, J.M. A hybrid epidemic model: Combining the advantages of agent-based and equation-based approaches. In Proceedings of the 39th Conference on Winter Simulation: 40 Years! The Best Is Yet to Come (WSC ‘07), Washington, DC, USA, 9-12 December 2007; pp. 1532-1537.

35. Han, W.; Huang, Z.; Kuerban, A.; Yan, M.; Fu, H. A Mask Detection Method for Shoppers under the Threat of COVID-19 Coronavirus. In Proceedings of the 2020 International Conference on Computer Vision, Image and Deep Learning (CVIDL), Chongqing, China, 10-12 July 2020; pp. 442-447. [CrossRef]

36. Ponnambalam, L.; Xiuju, F.; Goh, R.S.M.; Sarawgi, D. A multi-agent model for adaptive vaccination during infectious disease outbreaks. In Proceedings of the 2016 International Conference on Computing Technologies and Intelligent Data Engineering (ICCTIDE'16), Kovilpatti, India, 7-9 January 2016; pp. 1-5. [CrossRef]

37. Lin, B.; Mu, Y.; Li, C.; Duan, X. A Network for Detecting Facial Features during the COVID-19 Epidemic. In Proceedings of the 5th International Conference on Control Engineering and Artificial Intelligence (CCEAI 2021), Sanya, China, 14-16 January 2021; Association for Computing Machinery: New York, NY, USA, 2021; pp. 141-146. [CrossRef]

38. Fitzsimons, J.K.; Mantri, A.; Pisarczyk, R.; Rainforth, T.; Zhao, Z. A note on blind contact tracing at scale with applications to the COVID-19 pandemic. In Proceedings of the 15th International Conference on Availability, Reliability and Security (ARES 2020), Virtual Event, Ireland, 25-28 August 2020; ACM: New York, NY, USA, 2020; pp. 1-6. [CrossRef]

39. Kaviya, V.; Vedhashree, D.; Rani, T.P. A Novel COVID Prevention Method Using Deep Learning. In Proceedings of the 2020 International Conference on Power, Energy, Control and Transmission Systems (ICPECTS), Chennai, India, 10-11 December 2020; pp. 1-11. [CrossRef]

40. Raj, N.; Dasgotra, A.; Singh, V.K.; Mondal, S.; Sharma, A.; Pandey, J.K. A novel method of mass disinfection for the prevention of COVID-19. Int. J. Curr. Res. Rev. 2021, 3, 29-32. [CrossRef]

41. Whaiduzzaman; Hossain, R.; Shovon, A.R.; Roy, S.; Laszka, A.; Buyya, R.; Barros, A. A Privacy-Preserving Mobile and Fog Computing Framework to Trace and Prevent COVID-19 Community Transmission. IEEE J. Biomed. Health Inform. 2020, 24, 3564-3575. [CrossRef]

42. Hung, L.P.; Hsieh, N.C.; Chen, C.L. A RFID-Based Infection Prevention and Control Mechanism in Aged Care Living Residences Mobile Netw. Appl. 2021. [CrossRef]

43. Elahraf, A.; Afzal, A.; Akhtar, A.; Shafiq, B.; Vaidya, J. A Service-oriented Framework for Developing Personalized Patient Care Plans for COVID-19. In Proceedings of the DG.O'2021: The 22nd Annual International Conference on Digital Government Research (DG.O'21), Omaha, NE, USA, 9-11 June 2021; ACM: New York, NY, USA, 2021; pp. 1-8. [CrossRef]

44. Wang, R.; Ji, C.; Jiang, Z.; Wu, Y.; Yin, L.; Li, Y. A Short-Term Prediction Model at the Early Stage of the COVID-19 Pandemic Based on Multisource Urban Data. IEEE Trans. Comput. Soc. Syst. 2021. [CrossRef]

45. Khanfor, A.; Friji, H.; Ghazzai, H.; Massoud, Y. A Social IoT-Driven Pedestrian Routing Approach during Epidemic Time. In Proceedings of the 2020 IEEE Global Conference on Artificial Intelligence and Internet of Things (GCAIoT), Dubai, United Arab Emirates, 12-16 December 2020; pp. 1-6. [CrossRef] 
46. Zhou, X.; Yang, F.; Feng, Y.; Li, Q.; Tang, F.; Hu, S.; Lin, Z.; Zhang, L. A Spatial-Temporal Method to Detect Global Influenza Epidemics Using Heterogeneous Data Collected from the Internet. IEEE/ACM Trans. Comput. Biol. Bioinform. 2018, 15, 802-812. [CrossRef] [PubMed]

47. Ekpenyong, M.; Udo, I.; Uzoka, F.M.; Attai, K. A Spatio-GraphNet Model for Real-time Contact Tracing of COVID-19 Infection in Resource Limited Settings. In Proceedings of the 4th International Conference on Medical and Health Informatics (ICMHI 2020), Kamakura, Japan, 14-16 August 2020; Association for Computing Machinery: New York, NY, USA, 2020; pp. 208-217. [CrossRef]

48. Bian, S.; Zhou, B.; Bello, H.; Lukowicz, P. A Wearable Magnetic Field Based Proximity Sensing System for Monitoring COVID-19 Social Distancing. In Proceedings of the 2020 International Symposium on Wearable Computers (ISWC '20), Virtual Event, Mexico, 12-16 September 2020; ACM: New York, NY, USA, 2020; pp. 1-5. [CrossRef]

49. Iqbal, M.Z.; Faiz, M.F.I. Active Surveillance for COVID-19 Through Artificial Intelligence Using Real-Time Speech-Recognition Mobile Application. In Proceedings of the 2020 IEEE International Conference on Consumer Electronics-Taiwan (ICCE-Taiwan), Taoyuan, Taiwan, 28-30 September 2020; pp. 1-2. [CrossRef]

50. Jiang, J.-A.; Wang, J.-C.; Hsieh, C.-L.; Tseng, K.-S.; Ye, Z.-W.; Su, L.-K.; Sun, C.-H.; Wen, T.-H.; Juang, J.-Y. An Alternative Body Temperature Measurement Solution: Combination of a Highly Accurate Monitoring System and a Visualized Public Health Cloud Platform. IEEE Internet Things J. 2021, 8, 5778-5793. [CrossRef]

51. Abrar, M.M.; Islam, R.; Shanto, M.A.H. An Autonomous Delivery Robot to Prevent the Spread of Coronavirus in Product Delivery System. In Proceedings of the 2020 11th IEEE Annual Ubiquitous Computing, Electronics \& Mobile Communication Conference (UEMCON), New York, NY, USA, 28-31 October 2020; pp. 461-466. [CrossRef]

52. Kumar, M.; Singh, A.; Cherifi, H. An Efficient Immunization Strategy Using Overlapping Nodes and Its Neighborhoods. In Companion Proceedings of the Web Conference 2018 (WWW '18), Lyon, France, 23-27 April 2018; International World Wide Web Conferences Steering Committee: Geneva, Switzerland, 2018; pp. 1269-1275. [CrossRef]

53. Messina, G.; Della Camera, A.; Ferraro, P.; Amodeo, D.; Corazza, A.; Nante, N.; Cevenini, G. An Emerging Innovative UV Disinfection Technology (Part II): Virucide Activity on SARS-CoV-2. Int. J. Environ. Res. Public Health 2021, 18, 3873. [CrossRef]

54. Venusamyand, K.; Basha, R.F.K. An enhanced, contactless, IoT based operation of power appliances for COVID-19 isolation zone. J. Green Eng. 2020, 10, 4577-4583.

55. Mao, K.; Zhang, H.; Yang, Z. An integrated biosensor system with mobile health and wastewater-based epidemiology (iBMW) for COVID-19 pandemic. J. Biosens. Bioelectron. 2020, 169, 112617. [CrossRef]

56. Bilandi, N.; Verma, H.K.; Dhir, R. An Intelligent and Energy-Efficient Wireless Body Area Network to Control Coronavirus Outbreak. Arab. J. Sci. Eng. 2021. [CrossRef]

57. Lee, E.K.; Pietz, F.H.; Chen, C.H.; Liu, Y. An Interactive Web-based Decision Support System for Mass Dispensing, Emergency Preparedness, and Biosurveillance. In Proceedings of the 2017 International Conference on Digital Health (DH '17), London, UK, 2-5 July 2017; Association for Computing Machinery: New York, NY, USA, 2017; pp. 137-146. [CrossRef]

58. Deodhar, S.; Bisset, K.R.; Chen, J.; Ma, Y.; Marathe, M.V. An Interactive, Web-Based High Performance Modeling Environment for Computational Epidemiology. ACM Trans. Manag. Inf. Syst. 2014, 5, 1-27. [CrossRef] [PubMed]

59. Vishnu, S.; Jino Ramson, S.R. An Internet of Things Paradigm: Pandemic Management (incl. COVID-19). In Proceedings of the 2021 International Conference on Artificial Intelligence and Smart Systems (ICAIS), Coimbatore, India, 25-27 March 2021; pp. 1371-1375. [CrossRef]

60. Hafsiya, T.H.; Rose, B. An IoT-Cloud Based Health Monitoring Wearable Device for COVID Patients. In Proceedings of the 2021 7th International Conference on Advanced Computing and Communication Systems (ICACCS), Coimbatore, India, 19-20 March 2021; pp. 266-269. [CrossRef]

61. Tan, W.; Bian, R.; Yang, W.; Hou, Y. Analysis of 2019-nCoV epidemic situation based on modified SEIR model and DSGE algorithm. In Proceedings of the 2020 5th International Conference on Information Science, Computer Technology and Transportation (ISCTT), Shenyang, China, 13-15 November 2020; pp. 369-376. [CrossRef]

62. Gupta, R.; Bedi, M.; Goyal, P.; Wadhera, S.; Verma, V. Analysis of COVID-19 Tracking Tool in India: Case Study of Aarogya Setu Mobile Application. Digit. Gov. Res. Pract. 2020, 1, 28. [CrossRef]

63. Wan, X. Application of Semantic Location Awareness Computing Based on Data Mining in COVID-19 Prevention and Control System. J. Intell. Fuzzy Syst. 2020, 39, 8971-8980. [CrossRef]

64. Lin, W.L.; Hsieh, C.H.; Chen, T.S.; Chen, J.; Lee, J.L.; Chen, W.C. Apply IOT technology to practice a pandemic prevention body temperature measurement system: A case study of response measures for COVID-19. Int. J. Distrib. Sens. Netw. 2021. [CrossRef]

65. Tran, P.V.; Nguyen, H.T.; Tran, T.V. Approaching multi-dimensional cube for visualization-based epidemic warning systemDengue fever. In Proceedings of the 8th International Conference on Ubiquitous Information Management and Communication (ICUIMC '14), Siem Reap, Cambodia, 9-11 January 2014; Association for Computing Machinery: New York, NY, USA, 2014; pp. 1-8. [CrossRef]

66. Raj, D.; Srikanth, T.K. Assisted Telemedicine Model for Rural Healthcare Ecosystem. In Proceedings of the 13th ACM Web Science Conference 2021 (WebSci'21 Companion), Virtual Event, UK, 21-25 June 2021; ACM: New York, NY, USA, 2021; pp. 1-6. [CrossRef]

67. Akshat, A.; Nanda, V.; Singhal, A.; Jindal, S.K. AT89S52-Microcontroller Based Elevator with UV-C disinfection to prevent the transmission of COVID-19. In Proceedings of the 2020 International Conference on Interdisciplinary Cyber Physical Systems (ICPS), Chennai, India, 28-29 December 2020; pp. 25-30. [CrossRef] 
68. Jumlongkul, A. Automated AMBU Ventilator with Negative Pressure Headbox and Transporting Capsule for COVID-19 Patient Transfer. J. Front. Robot. AI 2021, 7, 221. [CrossRef]

69. Sudharsan, B.; Sundaram, D.; Breslin, J.G.; Ali, M.I. Avoid Touching Your Face: A Hand-to-face 3D Motion Dataset (COVID-away) and Trained Models for Smartwatches. In Proceedings of the 10th International Conference on the Internet of Things Companion (IoT '20 Companion), Malmö, Sweden, 6-9 October 2020; ACM: New York, NY, USA, 2020; pp. 1-9. [CrossRef]

70. Fu, Z.; Wu, Y.; Zhang, H.; Hu, Y.; Zhao, D.; Yan, R. Be Aware of the Hot Zone: A Warning System of Hazard Area Prediction to Intervene Novel Coronavirus COVID-19 Outbreak. In Proceedings of the 43rd International ACM SIGIR Conference on Research and Development in Information Retrieval (SIGIR '20), Virtual Event, China, 25-30 July 2020; ACM: New York, NY, USA, 2020; pp. 2241-2250. [CrossRef]

71. Mwamnyange, M.; Luhanga, E.; Thodge, S.R. Big Data Analytics Framework for Childhood Infectious Disease Surveillance and Response System using Modified MapReduce Algorithm A Case Study of Tanzania. Int. J. Adv. Comput. Sci. Appl. IJACSA 2021, 12. [CrossRef]

72. Singh, M.; Aujla, G.S.; Bali, R.S.; Vashisht, S.; Singh, A.; Jindal, A. Blockchain-enabled secure communication for drone delivery: A case study in COVID-like scenarios. In Proceedings of the 2nd ACM MobiCom Workshop on Drone Assisted Wireless Communications for 5G and Beyond (DroneCom '20), London, UK, 25 September 2020; Association for Computing Machinery: New York, NY, USA, 2020; pp. 25-30. [CrossRef]

73. Kielienyu, S.; Kantarci, B.; Turgut, D.; Khan, S. Bridging Predictive Analytics and Mobile Crowdsensing for Future Risk Maps of Communities Against COVID-19. In Proceedings of the 18th ACM International Symposium on Mobility Management and Wireless Access (MobiWac'20), Alicante, Spain, 16-20 November 2020; ACM: New York, NY, USA, 2020; pp. 1-9. [CrossRef]

74. Zhu, L.; Chen, P.; Dong, D.; Wang, Z. Can artificial intelligence enable the government to respond more effectively to major public health emergencies?-Taking the prevention and control of COVID-19 in China as an example. J. Socio-Econ. Plan. Sci. 2021, 101029. [CrossRef]

75. Roy, A.; Kar, B. Characterizing the Spread of COVID-19 from Human Mobility Patterns and SocioDemographic Indicators. In Proceedings of the 3rd ACM SIGSPATIAL Workshop on Advances in Resilient and Intelligent Cities (ARIC'20), Seattle, WA, USA, 3-6 November 2020; ACM: New York, NY, USA, 2020; pp. 39-48. [CrossRef]

76. Shenvi, D.R.; Shet, K. CNN Based COVID-19 Prevention System. In Proceedings of the 2021 International Conference on Artificial Intelligence and Smart Systems (ICAIS), Coimbatore, India, 25-27 March 2021; pp. 873-878. [CrossRef]

77. Deng, S.; Wang, S.; Rangwala, H.; Wang, L.; Ning, Y. Cola-GNN: Cross-location Attention based Graph Neural Networks for Long-term ILI Prediction. In Proceedings of the 29th ACM International Conference on Information and Knowledge Management (CIKM '20), Virtual Event, Ireland, 19-23 October 2020; ACM: New York, NY, USA, 2020; pp. 245-254. [CrossRef]

78. Leong, K.; Si, Y.; Biuk-Aghai, R.P.; Fong, S. Contact tracing in healthcare digital ecosystems for infectious disease control and quarantine management. In Proceedings of the 2009 3rd IEEE International Conference on Digital Ecosystems and Technologies, Istanbul, Turkey, 1-3 June 2009; pp. 306-311. [CrossRef]

79. Stojanovic, D.; Vujovic, M. Contactless and context-aware decision making for automated building access systems. In Proceedings of the Projections-Proceedings of the 26th International Conference of the Association for Computer-Aided Architectural Design Research in Asia, CAADRIA 2021, Online, Hong Kong, 29 March-1 April 2021; Volume 2, pp. 193-202.

80. Prince, A.; Chen, X.; Lun, K.C. Containing acute disease outbreak. Methods Inf. Med. 2005, 44, 603-608. [CrossRef]

81. Bairagi, A.K.; Masud, M.; Kim, D.H.; Munir, S.; Nahid, A.-A.; Abedin, S.F.; Alam, K.M.; Biswas, S.; Alshamrani, S.S.; Han, Z.; et al Controlling the Outbreak of COVID-19: A Noncooperative Game Perspective. IEEE Access 2020, 8, 215570-215581. [CrossRef]

82. Cheng, W.; Chen, F.; Cheng, X. Controlling the Spreads of Infectious Disease and Scare via Utilizing Location and Social Networking Information. In Proceedings of the 2015 Workshop on Mobile Big Data (Mobidata '15), Hangzhou, China, 21 June 2015; Association for Computing Machinery: New York, NY, USA, 2015; pp. 1-5. [CrossRef]

83. Sim, S.; Cho, M. Convergence model of AI and IoT for virus disease control system. J. Pers. Ubiquitous Comput. 2021. [CrossRef]

84. Liu, Z.; Zuo, J.; Lv, R.; Liu, S.; Wang, W. Coronavirus Epidemic (COVID-19) Prediction and Trend Analysis Based on Time Series. In Proceedings of the 2021 IEEE International Conference on Artificial Intelligence and Industrial Design (AIID), Guangzhou, China, 28-30 May 2021; pp. 35-38. [CrossRef]

85. Ashwin, V.; Menon, A.; Devagopal, A.M.; Nived, P.A.; Gopinath, A.; Gayathri, G.; Shibu, N.B.S. Cost-Effective Device for Autonomous Monitoring of the Vitals for COVID-19 Asymptomatic Patients in Home Isolation Treatment. In Advances in Computing and Network Communications. Lecture Notes in Electrical Engineering, Vol 735. Proceedings of the 4th International Conference on Computing and Network Communications, CoCoNet 2020, 14-17 October 2020; Thampi, S.M., Gelenbe, E., Atiquzzaman, M., Chaudhary, V., Li, K.C., Eds.; Springer: Singapore, 2021. [CrossRef]

86. Haritha, D.; Pranathi, M.K.; Reethika, M. COVID Detection from Chest X-rays with DeepLearning: CheXNet. In Proceedings of the 2020 5th International Conference on Computing, Communication and Security (ICCCS), Patna, India, 14-16 October 2020; pp. 1-5. [CrossRef]

87. Yan, Q.; Wang, B.; Gong, D.; Luo, C.; Zhao, W.; Shen, J.; Ai, J.; Shi, Q.; Zhang, Y.; Jin, S.; et al. COVID-19 Chest CT Image Segmentation Network by Multi-Scale Fusion and Enhancement Operations. IEEE Trans. Big Data 2021, 7, 13-24. [CrossRef] 
88. Lin, T.C.; Lee, H.C. COVID-19 Chest Radiography Images Analysis Based on Integration of Image Preprocess, Guided GradCAM, Machine Learning and Risk Management. In Proceedings of the 4th International Conference on Medical and Health Informatics (ICMHI 2020), Kamakura, Japan, 14-16 August 2020; Association for Computing Machinery: New York, NY, USA, 2020; pp. 281-288. [CrossRef]

89. Huang, H. COVID-19 CT Image Recognition Based on Multi-stage Transfer Learning. In Proceedings of the 2020 International Conference on Aviation Safety and Information Technology (ICASIT 2020), Weihai, China, 14-16 October 2020; ACM: New York, NY, USA, 2020; pp. 682-688. [CrossRef]

90. Zhou, C.; Song, J.; Zhou, S.; Zhang, Z.; Xing, J. COVID-19 Detection Based on Image Regrouping and Resnet-SVM Using Chest X-Ray Images. IEEE Access 2021, 9, 81902-81912. [CrossRef]

91. Thakur, G.; Sparks, K.; Berres, A.; Tansakul, V.; Chinthavali, S.; Whitehead, M.; Schmidt, E.; Xu, H.; Fan, J.; Spears, D.; et al. COVID-19 Joint Pandemic Modeling and Analysis Platform. In Proceedings of the 1st ACM SIGSPATIAL International Workshop on Modeling and Understanding the Spread of COVID-19 (COVID-19), Seattle, WA, USA, 3 November 2020; ACM: New York, NY, USA, 2020; pp. 1-10. [CrossRef]

92. Tangtisanon, P. COVID-19 Pandemic Prevention Mobile Application for on Campus Classroom. In Proceedings of the 2021 IEEE 6th International Conference on Computer and Communication Systems (ICCCS), Chengdu, China, 23-26 April 2021; pp. 1117-1121. [CrossRef]

93. Phankokkruad, M. COVID-19 Pneumonia Detection in Chest X-ray Images Using Transfer Learning of Convolutional Neural Networks. In Proceedings of the 2020 3rd International Conference on Data Science and Information Technology (DSIT'20), Xiamen, China, 24-26 July 2020; pp. 147-152. [CrossRef]

94. Khriji, L.; Ammari, A.; Messaoud, S.; Bouaafia, S.; Maraoui, A.; Machhout, M. COVID-19 Recognition Based on Patient's Coughing and Breathing Patterns Analysis: Deep Learning Approach. In Proceedings of the 2021 29th Conference of Open Innovations Association (FRUCT), Tampere, Finland, 12-14 May 2021; pp. 185-191. [CrossRef]

95. Zhou, T.; Zhang, Y. COVID-19 Spread Prediction Model. In Proceedings of the 2nd International Conference on Computing and Data Science (CONFCDS 2021), Stanford, CA, USA, 28-30 January 2021; ACM: New York, NY, USA, 2021; pp. 1-6. [CrossRef]

96. Rimsan, M.; Mahmood, A.K.; Umair, M.; Hassan, F. COVID-19: A Novel Framework to Globally Track Coronavirus Infected Patients using Blockchain. In Proceedings of the 2020 International Conference on Computational Intelligence (ICCI), Bandar Seri Iskandar, Malaysia, 8-9 October 2020; pp. 70-74. [CrossRef]

97. Satu, S.; Rahman, K.; Alam Rony, M.; Shovon, A.R.; Alam Adnan, J.; Howlader, K.C.; Kaiser, M.S. COVID-19: Update, Forecast and Assistant-An Interactive Web Portal to Provide Real-Time Information and Forecast COVID-19 Cases in Bangladesh. In Proceedings of the 2021 International Conference on Information and Communication Technology for Sustainable Development (ICICT4SD), Dhaka, Bangladesh, 27-28 February 2021; pp. 456-460. [CrossRef]

98. Kocsisné, G.S.; Attila, K. COVID-19's Telemedicine Platform. In Information Science and Applications; Lecture Notes in Electrical Engineering; Springer: Singapore, 2021; Volume 739. [CrossRef]

99. Tsoumalis, G.; Bampos, Z.; Papazoglou, A.; Iakovakis, D.; Hadjidimitriou, S.; Apostolidis, G.; Charisis, V.; Jelinek, H.; Khandoker, A.; Khalaf, K.; et al. CovidSense: A Smartphone-based Initiative for Fighting COVID-19 Spreading. In Proceedings of the 9th International Conference on Software Development and Technologies for Enhancing Accessibility and Fighting Info-exclusion (DSAI 2020), Online, Portugal, 2-4 December 2020; Association for Computing Machinery: New York, NY, USA, 2020; pp. 87-92. [CrossRef]

100. Cisneros, B.; Ye, J.; Park, C.H.; Kim, Y. CoviReader: Using IOTA and QR Code Technology to Control Epidemic Diseases across the US. In Proceedings of the 2021 IEEE 11th Annual Computing and Communication Workshop and Conference (CCWC), Virtual, 27-30 January 2021; pp. 610-618. [CrossRef]

101. Das Mohapatra, S.; Nayak, S.C.; Parida, S.; Panigrahi, C.R.; Pati, B. COVTrac: COVID-19 Tracker and Social Distancing App. In Progress in Advanced Computing and Intelligent Engineering. Advances in Intelligent Systems and Computing; Panigrahi, C.R., Pati, B., Pattanayak, B.K., Amic, S., Li, K.C., Eds.; Springer: Singapore, 2021; Volume 1299. [CrossRef]

102. Saxena, T.; Anuragi, P.; Shinde, G.; Yadav, N.; Digalwar, M. COWAR: An Android Based Mobile Application to Help Citizens and COVID-19 Warriors. In Proceedings of the 2020 IEEE 4th Conference on Information \& Communication Technology (CICT), Chennai, India, 3-5 December 2020; pp. 1-6. [CrossRef]

103. Cerit, B.; Bayir, R. Deep learning based mask detection in smart home entries during the epidemic process. Int. Arch. Photogramm. Remote. Sens. Spat. Inf. Sci. 2020, 44, 159-163. [CrossRef]

104. Jeny, J.R.V.; Shraddha, B.; Ashritha, B.; Sai, D.S.; Naveen, M. Deep Learning Framework for Face Mask Detection. In Proceedings of the 2021 th International Conference on Trends in Electronics and Informatics (ICOEI), Tirunelveli, India, 3-5 June 2021; pp. 1705-1712. [CrossRef]

105. Mao, P.; Hao, P.; Xin, Y. Deep Learning Implementation of Facemask Detection. In Proceedings of the 2nd International Conference on Computing and Data Science (CONFCDS 2021), Stanford, CA, USA, 28-30 January 2021; ACM: New York, NY, USA, 2021; pp. 1-4. [CrossRef]

106. Herbert, J.; Horsham, C.; Ford, H.; Wall, A.; Hacker, E. Deployment of a smart handwashing station in a school setting during the COVID-19 pandemic: Field study. JMIR Public Health Surveill. 2020, 6, e22305. [CrossRef]

107. Albusac, J.; Castro-Schez, J.J.; Castro-Garcia, M.; Perez-Flores, J.C.; Canales-Vazquez, J. Design and Evaluation of a System for Decentralized Management of Solidarity Actions during the COVID-19 Crisis. Appl. Sci. 2020, 10, 8064. [CrossRef] 
108. Verbelen, Y.; Kaluvan, S.; Haller, U.; Boardman, M.; Scott, T.B. Design and Implementation of a Social Distancing and Contact Tracing Wearable. In Proceedings of the 2020 6th IEEE Congress on Information Science and Technology (CiSt), Agadir, Essaouira, Morocco, 5-12 June 2020; pp. 466-471. [CrossRef]

109. Arief, U.M.; Subiyanto, S.; Andrasto, T.; Sukamta, S.; Sulistyawan, V.N.; Sarwono, E.; Alfian, A.A.; Wicaksono, P.; Amelia, P.N.; Putra, A.D.H. Design of hexacopter UAV system for disinfectant spraying. IOP Conf. Ser. Earth Environ. Sci. 2020, 700, 012023. [CrossRef]

110. Li, X.; Wang, S. Design of Infectious Disease Prevention and Control Platform Based on Big Data Analysis of Location Information. In Proceedings of the 2020 4th International Conference on Electronic Information Technology and Computer Engineering (EITCE 2020), Xiamen, China, 6-8 November 2020; Association for Computing Machinery: New York, NY, USA, 2020; pp. 1-5. [CrossRef]

111. Putra, D.D.; Febriyanto, M.; Nadra, M.M.; Shalannanda, W.; Firzal, E.R.; Munir, A. Design of Smart-Gate Based on Artificial Intelligence Possibly for COVID-19 Early Prevention at Public Area. In Proceedings of the 2020 14th International Conference on Telecommunication Systems, Services and Applications (TSSA), Bandung, Indonesia, 4-5 November 2020; pp. 1-4. [CrossRef]

112. Lee, B.; Lee, M.; Mogk, J.; Goldstein, R.; Bibliowicz, J.; Tessier, A. Designing a Multi Agent Occupant Simulation System to Support Facility Planning and Analysis for COVID19. In Proceedings of the Designing Interactive Systems Conference 2021 (DIS '21), Virtual Event, USA, 28 June-2 July 2021; ACM: New York, NY, USA, 2021; pp. 1-16. [CrossRef]

113. Zetterholm, M.; Elm, P.; Salavati, S. Designing for pandemics-A design concept based on technology mediated nudging for health behavior change. In Proceedings of the 54th Hawaii International Conference on System Sciences, Kauai, HI, USA, 4-8 January 2021; pp. 3474-3483. [CrossRef]

114. Souza, R.C.S.N.P.; Assunção, R.M.; Neill, D.B.; Meira, W. Detecting Spatial Clusters of Disease Infection Risk Using Sparsely Sampled Social Media Mobility Patterns. In Proceedings of the 27th ACM SIGSPATIAL International Conference on Advances in Geographic Information Systems (SIGSPATIAL '19), Chicago, IL, USA, 5-8 November 2019; Association for Computing Machinery: New York, NY, USA, 2019; pp. 359-368. [CrossRef]

115. Kumar, R.N.V.; Arun, M.; Baraneetharan, E.; Prakash, S.J.J.; Kanchana, A.; Prabu, S. Detection and monitoring of the asymptotic COVID-19 patients using IoT devices and sensors. Int. J. Pervasive Comput. Commun. 2020. [CrossRef]

116. Ashraf, M.U.; Hannan, A.; Cheema, S.M.; Ali, Z.; Jambi, K.M.; Alofi, A. Detection and Tracking Contagion using IoT-Edge Technologies: Confronting COVID-19 Pandemic. In Proceedings of the 2020 International Conference on Electrical Communication and Computer Engineering (ICECCE), Istanbul, Turkey, 12-13 June 2020; pp. 1-6. [CrossRef]

117. Umri, B.K.; Wafa Akhyari, M.; Kusrini, K. Detection of COVID-19 in Chest X-ray Image using CLAHE and Convolutional Neural Network. In Proceedings of the 2020 2nd International Conference on Cybernetics and Intelligent System (ICORIS), Manado, Indonesia, 27-28 October 2020; pp. 1-5. [CrossRef]

118. López, J.H.; Romo, S.; Molina, D.C.; Hernández, G..; Cureño, .B.G.; Acosta, M.A.; Gaxiola, C.A.A.; Félix, M.J.S.; Galván, T.G. Detection of SARS-CoV-2 in the air of two hospitals in Hermosillo, Sonora, México, utilizing a low-cost environmental monitoring system. Int. J. Infect. Dis. 2021, 102, 478-482. [CrossRef]

119. Somaldo, P.; Ferdiansyah, F.A.; Jati, G.; Jatmiko, W. Developing Smart COVID-19 Social Distancing Surveillance Drone using YOLO Implemented in Robot Operating System simulation environment. In Proceedings of the 2020 IEEE 8th R10 Humanitarian Technology Conference (R10-HTC), Kuching, Malaysia, 1-3 December 2020; pp. 1-6. [CrossRef]

120. Jung, H.J.; Jung, G.S.; Kim, Y.; Khan, N.T.; Kim, Y.H.; Kim, Y.B.; Park, J.S. Development and appplication of agent-bsed disease spread simulation model: The case of suwon, Korea. In Proceedings of the 2017 Winter Simulation Conference (WSC '17), Las Vegas, NV, USA, 3-6 December 2017; pp. 1-11.

121. Zaeni, I.A.E.; Sendari, S.; bin Mahamad, A.K. Development of The Personnel Monitoring System Using Mobile Application and Real-Time Database during the COVID19 Pandemic. In Proceedings of the 2020 3rd International Seminar on Research of Information Technology and Intelligent Systems (ISRITI), Yogyakarta, Indonesia, 10-11 December 2020; pp. 371-376. [CrossRef]

122. Lian, W.; Wen, L.; Zhou, Q.; Zhu, W.; Duan, W.; Xiao, X.; Mhungu, F.; Huang, W.; Li, C.; Cheng, W.; et al. Digital health technologies respond to the COVID-19 pandemic in a tertiary hospital in China: Development and usability study. J. Med. Internet Res. 2020, 22, e24505. [CrossRef]

123. Cencetti, G.; Santin, G.; Longa, A.; Pigani, E.; Barrat, A.; Cattuto, C.; Lehmann, S.; Salathe, M.; Lepri, B. Digital proximity tracing on empirical contact networks for pandemic control. Nat. Commun. 2021, 12, 1655. [CrossRef] [PubMed]

124. Karel, F.B. Disinfection of Klebsiella pneumoniae using ultrasonic systems. J. Environ. Biol. 2015, 37, $1013-1019$.

125. Schneckenreither, G.; Popper, N. Dynamic multiplex social network models on multiple time scales for simulating contact formation and patterns in epidemic spread. In Proceedings of the 2017 Winter Simulation Conference (WSC '17), Las Vegas, NV, USA, 3-6 December 2017; pp. 1-12.

126. Nie, Q.; Liu, Y.; Zhang, D.; Jiang, H. Dynamical SEIR Model with Information Entropy Using COVID-19 as a Case Study. IEEE Trans. Comput. Soc. Syst. 2021, 8, 946-954. [CrossRef]

127. Douhan, W.; Qinneng, X. Economic Evaluation of Quarantine: A Case Study of COVID-19 Pandemic in Belgium. In Proceedings of the 2020 5th International Conference on Intelligent Informatics and Biomedical Sciences (ICIIBMS), Okinawa, Japan, 18-20 November 2020; pp. 99-102. [CrossRef]

128. Dibble, C. Effective real-time allocation of pandemic interventions. In Proceedings of the Winter Simulation Conference (WSC '10), Baltimore, MD, USA, 5-8 December 2010; pp. 2211-2220. 
129. Ramos, M.; Sánchez, J.; Muñoz, V.; Romero, J.R.M.; Cruz, D.V.; López, A.L.; Ramos, F. E-health: Agent-based models to simulate behavior of individuals during an epidemic outbreak. In Proceedings of the 19th Annual International Conference on Digital Government Research: Governance in the Data Age (DG.O '18), Delft, The Netherlands, 30 May-1 June 2018; Association for Computing Machinery: New York, NY, USA, 2018; pp. 1-10. [CrossRef]

130. Wang, Z.; Xia, C.; Chen, Z.; Chen, G. Epidemic Propagation with Positive and Negative Preventive Information in Multiplex Networks. IEEE Trans. Cybern. 2021, 51, 1454-1462. [CrossRef]

131. Barrett, C.L.; Bisset, K.R.; Eubank, S.G.; Feng, X.; Marathe, M.V. EpiSimdemics: An efficient algorithm for simulating the spread of infectious disease over large realistic social networks. In Proceedings of the $2008 \mathrm{ACM} / \mathrm{IEEE}$ conference on Supercomputing (SC ‘08), Austin, TX, USA, 15-21 November 2008; pp. 1-12.

132. Comito, C.; Forestiero, A.; Papuzzo, G. Exploiting Social Media to enhance Clinical Decision Support. In Proceedings of the IEEE/WIC/ACM International Conference on Web Intelligence-Companion Volume (WI '19 Companion), Thessaloniki, Greece, 14-17 October 2019; Association for Computing Machinery: New York, NY, USA, 2019; pp. 244-249. [CrossRef]

133. Brown, C.; Chauhan, J.; Grammenos, A.; Han, J.; Hasthanasombat, A.; Spathis, D.; Xia, T.; Cicuta, P.; Mascolo, C. Exploring Automatic Diagnosis of COVID-19 from Crowdsourced Respiratory Sound Data. In Proceedings of the 26th ACM SIGKDD Conference on Knowledge Discovery and Data Mining (KDD '20), Virtual Event, CA, USA, 23-27 August 2020; ACM: San Diego, CA, USA, 2020; pp. 3474-3484. [CrossRef]

134. Nguyen, M.T.; Nguyen, T.T. Extraction of disease events for a real-time monitoring system. In Proceedings of the Fourth Symposium on Information and Communication Technology (SoICT '13), Danang, Vietnam, 5-6 December 2013; Association for Computing Machinery: New York, NY, USA, 2013; pp. 139-147. [CrossRef]

135. Shamrat, F.M.J.M.; Chakraborty, S.; Billah, M.M.; Jubair, M.A.; Islam, M.S.; Ranjan, R. Face Mask Detection using Convolutional Neural Network (CNN) to reduce the spread of COVID-19. In Proceedings of the 20215 th International Conference on Trends in Electronics and Informatics (ICOEI), Tirunelveli, India, 3-5 June 2021; pp. 1231-1237. [CrossRef]

136. Kodali, R.K.; Dhanekula, R. Face Mask Detection Using Deep Learning. In Proceedings of the 2021 International Conference on Computer Communication and Informatics (ICCCI), Pattaya, Thailand, 10-12 March 2021; pp. 1-5. [CrossRef]

137. Singh, S.; Ahuja, U.; Kumar, M.; Kumar, K.; Sachdeva, M. Face mask detection using YOLOv3 and faster R-CNN models: COVID-19 environment. Multimed. Tools Appl. 2021, 80, 19753-19768. [CrossRef] [PubMed]

138. Sethi, K.; Kaul, S.; Patel, I.; Sujatha, R. FaceLock Homes: A Contactless Smart Home Security System to Prevent COVID Transmission. In Proceedings of the 2021 Sixth International Conference on Wireless Communications, Signal Processing and Networking (WiSPNET), Chennai, India, 25-27 March 2021; pp. 75-79. [CrossRef]

139. Piombino, P.; Committeri, U.; Norino, G.; Vaira, L.A.; Troise, S.; Maglitto, F.; Mariniello, D.; De Riu, G.; Califano, L. Facing COVID-19 pandemic: Development of custom-made face mask with rapid prototyping system. J. Infect. Dev. Ctries. 2021, 15, 51-57. [CrossRef] [PubMed]

140. Xu, Q.; Su, Z.; Zhang, K.; Yu, S. Fast Containment of Infectious Diseases with E-healthcare Mobile Social Internet of Things. IEEE Internet Things J. 2021. [CrossRef]

141. Kongmanee, J.; Thanapattheerakul, T. Fine-Tuning A Lightweight Convolutional Neural Networks for COVID-19 Diagnosis. In Proceedings of the CSBio '20: Proceedings of the Eleventh International Conference on Computational Systems-Biology and Bioinformatics (CSBio2020), Bangkok, Thailand, 19-21 November 2020; Association for Computing Machinery: New York, NY, USA, 2020; pp. 101-103. [CrossRef]

142. Baldassi, F.; Cenciarelli, O.; Malizia, A.; Gaudio, P. First prototype of the infectious diseases seeker (IDS) software for prompt identification of infectious diseases. J. Epidemiol. Glob. Health 2020, 10, 367-377. [CrossRef]

143. Hossain, F.A.; Lover, A.A.; Corey, G.A.; Reich, N.G.; Rahman, T. FluSense: A Contactless Syndromic Surveillance Platform for Influenza-Like Illness in Hospital Waiting Areas. Proc. ACM Interact. Mob. Wearable Ubiquitous Technol. 2020, 4, 1-28. [CrossRef]

144. Chloros, D.; Ringas, D. Fluspot: Seasonal flu tracking app exploiting wearable IoT device for symptoms monitoring. In Proceedings of the SEEDA-CECNSM 2020 - 5th South-East Europe Design Automation, Computer Engineering, Computer Networks and Social Media Conference, SEEDA-CECNSM 2020, Virtual, 25-27 September 2020. [CrossRef]

145. Zhang, Q.; Perra, N.; Perrotta, D.; Tizzoni, M.; Paolotti, D.; Vespignani, A. Forecasting Seasonal Influenza Fusing Digital Indicators and a Mechanistic Disease Model. In Proceedings of the 26th International Conference on World Wide Web (WWW ‘17), Perth, Australia, 3-7 April 2017; pp. 311-319. [CrossRef]

146. Peng, S.; Bai, L.; Xiong, L.; Qu, Q.; Xie, X.; Wang, S. GeoAI-based Epidemic Control with Geo-Social Data Sharing on Blockchain. In Proceedings of the 2020 IEEE International Conference on E-health Networking, Application \& Services (HEALTHCOM), Shenzhen, China, 1-2 March 2021; pp. 1-6. [CrossRef]

147. Cetin, A.E.; Kocer, Z.A.; Topkaya, S.N.; Yazici, Z.A. Handheld plasmonic biosensor for virus detection in field-settings. Sens. Actuators B Chem. 2021, 344, 130301. [CrossRef] [PubMed]

148. Ndulue, C.; Orji, R. Heuristic Evaluation of an Africancentric Mobile Persuasive Game for Promoting Safety Measures against COVID-19. In Proceedings of the 3rd African Human-Computer Interaction Conference (AfriCHI 2021), Maputo, Mozambique, 8-12 March 2021; ACM: New York, NY, USA, 2021. [CrossRef] 
149. Kim, M.; Kang, J.; Kim, D.; Song, H.; Min, H.; Nam, Y.; Park, D.; Lee, J.G. Hi-COVIDNet: Deep Learning Approach to Predict Inbound COVID-19 Patients and Case Study in South Korea. In Proceedings of the 26th ACM SIGKDD Conference on Knowledge Discovery and Data Mining (KDD '20), Virtual Event, CA, USA, 23-27 August 2020; ACM: New York, NY, USA, 2020; pp. 3466-3473. [CrossRef]

150. Vu, A.Q.N.; Park, J.; Joo, K.; Thi, T.V.T.; Tran, T.T.; Choi, J. Human Face Recognition and Temperature Measurement Based on Deep Learning for COVID-19 Quarantine Checkpoint. In Proceedings of the 4th International Conference on Future Networks and Distributed Systems (ICFNDS) (ICFNDS'20), St. Petersburg, Russia, 26-27 November 2020; ACM: New York, NY, USA, 2020; pp. 1-6. [CrossRef]

151. Deligiannidis, L. Human Temperature Scanning from a Distance. In Proceedings of the 2020 International Conference on Computational Science and Computational Intelligence (CSCI), Las Vegas, NV, USA, 16-18 December 2020; pp. 1704-1705. [CrossRef]

152. Ilapakurti, A.; Vuppalapati, J.S.; Kedari, S.; Kedari, S.; Chauhan, C.; Vuppalapati, C. iDispenser-Big Data Enabled Intelligent Dispenser. In Proceedings of the 2017 IEEE Third International Conference on Big Data Computing Service and Applications (BigDataService), Redwood City, CA, USA, 6-9 April 2017; pp. 124-130. [CrossRef]

153. Pramudyo, R.W.; Susilo, R.A.; Aprilia, D.E. Improving infectious diseases prevention system: The case study of Departement of Health Sragen. In Proceedings of the 2015 International Conference on Information Technology Systems and Innovation (ICITSI), Bandung, Indonesia, 16-19 November 2015; pp. 1-6. [CrossRef]

154. Mei, S.; Zhu, Y.; Qiu, X.; Zhou, X.; Zu, Z.; Boukhanovsky, A.V.; Sloot, P.M. Individual Decision Making Can Drive Epidemics: A Fuzzy Cognitive Map Study. IEEE Trans. Fuzzy Syst. 2014, 22, 264-273. [CrossRef]

155. Ho, Y.H.; Li, P.E.; Chen, L.J.; Liu, Y.L. Indoor air quality monitoring system for proactive control of respiratory infectious diseases: Poster abstract. In Proceedings of the 18th Conference on Embedded Networked Sensor Systems (SenSys '20), Virtual Event, Japan, 16-19 November 2020; Association for Computing Machinery: New York, NY, USA, 2020; pp. 693-694. [CrossRef]

156. Srividya, K.; Nagaraj, S.; Puviyarasi, B.; Vani, S. Infection Prevention and Control using UV-Disinfectant Bot for COVID. In Proceedings of the 2021 2nd International Conference for Emerging Technology (INCET), Belagavi, India, 21-23 May 2021; pp. 1-5. [CrossRef]

157. Negishi, T.; Sun, G.; Sato, S.; Liu, H.; Matsui, T.; Abe, S.; Nishimura, H.; Kirimoto, T. Infection Screening System Using Thermography and CCD Camera with Good Stability and Swiftness for Non-contact Vital-Signs Measurement by Feature Matching and MUSIC Algorithm. In Proceedings of the 2019 41st Annual International Conference of the IEEE Engineering in Medicine and Biology Society (EMBC), Berlin, Germany, 23-27 July 2019; pp. 3183-3186. [CrossRef]

158. Feng, S.; Jin, Z. Infectious Diseases Spreading on an Adaptive Metapopulation Network. IEEE Access 2020, 8, 153425-153435. [CrossRef]

159. Wang, J.; Wang, X.; Wu, J. Inferring Metapopulation Propagation Network for Intra-city Epidemic Control and Prevention. In Proceedings of the 24th ACM SIGKDD International Conference on Knowledge Discovery \& Data Mining (KDD ‘18), London UK, 19-23 August 2018; Association for Computing Machinery: New York, NY, USA, 2018; pp. 830-838. [CrossRef]

160. Nikolov, I.; Madsen, C. Initial development of "Infection defender": A children's educational game for pandemic prevention measurements. In Proceedings of the 16th International Joint Conference on Computer Vision, Imaging and Computer Graphics Theory and Applications, VISIGRAPP 2021, Vienna, Austria, 8-10 February 2021; Volume 1, pp. 253-260. [CrossRef]

161. Charfeddine, M.; Montreuil, B. Integrated agent-oriented modeling and simulation of population and healthcare delivery network: Application to COPD chronic disease in a Canadian region. In Proceedings of the Winter Simulation Conference (WSC '10), Baltimore, MD, USA, 5-8 December 2010; pp. 2327-2339.

162. Henan, L.; Tiangang, L.; Yuefei, W. Intelligent Lighting System Design Based on UV LED Technology with the Functions of Air Sterilization, Disinfection, Purification and Mosquito Control. In Proceedings of the 2020 17th China International Forum on Solid State Lighting \& 2020 International Forum on Wide Bandgap Semiconductors China (SSLChina: IFWS), Shenzhen, China, 23-25 November 2020; pp. 117-122. [CrossRef]

163. Sathyaseelan, M.P.; Chakravarthi, M.K.; Sathyaseelan, A.P.; Sudipta, S. IoT based COVID De-Escalation System using Bluetooth Low Level Energy. In Proceedings of the 2021 6th International Conference on Inventive Computation Technologies (ICICT), Coimbatore, India, 20-22 January 2021; pp. 174-177. [CrossRef]

164. Saraubon, K.; Limthanmaphon, B. IoT Telemonitoring System for COVID-19 Quarantine. TEM J. 2021, 10, 105-112. [CrossRef]

165. Savaşc1, S.S.; Cicioğlu, M.; Çalhan, A. IoT-based GPS assisted surveillance system with inter-WBAN geographic routing for pandemic situations. J. Biomed. Inform. 2021, 116, 103731. [CrossRef]

166. Dhakal, P.; Damacharla, P.; Javaid, A.Y.; Vege, H.K.; Devabhaktuni, V.K. IVACS: Intelligent Voice Assistant for Coronavirus Disease (COVID-19) Self-Assessment. In Proceedings of the 2020 International Conference on Artificial Intelligence \& Modern Assistive Technology (ICAIMAT), Riyadh, Saudi Arabia, 24-26 November 2020; pp. 1-6. [CrossRef]

167. Zhao, Y.; Zhou, C.C. Link Analysis to Discover Insights from Structured and Unstructured Data on COVID-19. In Proceedings of the 11th ACM International Conference on Bioinformatics, Computational Biology and Health Informatics (BCB '20), Virtual Event, USA, 21-24 September 2020; ACM: New York, NY, USA, 2020; pp. 1-8. [CrossRef]

168. Kirkpatrick, A.W.; McKee, J.L.; Conly, J.M. Longitudinal remotely mentored self-performed lung ultrasound surveillance of paucisymptomatic COVID-19 patients at risk of disease progression. Ultrasound. J. 2021, 13, 27. [CrossRef] 
169. Gabrie, T.; Carrasco, A.M.; Avila, J.L.O. Low-cost Robot Assistance Design for Health Area to Help Prevent COVID19 in Honduras. In Proceedings of the 2020 6th International Conference on Robotics and Artificial Intelligence (ICRAI 2020), Singapore, 20-22 November 2020; ACM: New York, NY, USA, 2020. [CrossRef]

170. Vangipuram, S.K.; Appusamy, R. Machine learning framework for COVID-19 diagnosis. In Proceedings of the 3rd International Conference on Data Science, E-Learning and Information Systems, DATA 2021, Petra, Jordan, 5-7 April 2021; pp. 18-25. [CrossRef]

171. Wang, C.; Bu, L.; Xiao, H.; Qin, K. Mask Detection and Epidemic Prevention System. J. Phys. Conf. Ser. 2020, $1894,012019$. [CrossRef]

172. Pramita, M.D.; Kurniawan, B.; Utama, N.P. Mask Wearing Classification using CNN. In Proceedings of the 20207 th International Conference on Advance Informatics: Concepts, Theory and Applications (ICAICTA), Tokoname, Japan, 8-9 September 2020; pp. 1-4. [CrossRef]

173. Xu, M.; Wang, H.; Yang, S.; Li, R. Mask wearing detection method based on SSD-Mask algorithm. In Proceedings of the 2020 International Conference on Computer Science and Management Technology (ICCSMT), Shanghai, China, 20-22 November 2020; pp. 138-143. [CrossRef]

174. Kang, J.; Huang, N.; Liu, X. MAS-SEIR-II Simulation on COVID-19 in China. In Proceedings of the 2020 International Conference on Big Data in Management (ICBDM 2020), Manchester, UK, 15-17 May 2020; Association for Computing Machinery: New York, NY, USA, 2020; pp. 113-117. [CrossRef]

175. Hu, A.; Min, L.; Su, Y.; Kuang, Y. Mathematical analysis of an SIR network model with imperfect vaccination and varying size of population. In Proceedings of the 8th International Conference on Computer Modeling and Simulation (ICCMS '17), Canberra, Australia, 20-23 January 2017; Association for Computing Machinery: New York, NY, USA, 2017; pp. 7-13. [CrossRef]

176. Montalan, J.R.; Estuar, M.R.J.; Teknomo, K.; Gardon, R.W. Measles Metapopulation Modeling using Ideal Flow of Transportation Networks. In Proceedings of the 2nd International Conference on Software Engineering and Information Management (ICSIM 2019), Bali, Indonesia, 10-13 January 2019; Association for Computing Machinery: New York, NY, USA, 2019; pp. 147-151. [CrossRef]

177. Yang, Q.; on behalf of the Expert Committee of Medical Imaging Engineering and Technology Branch of the Chinese Society of Biomedical Engineering; Xu, H.; Tang, X.; Hu, C.; Wang, P.; Wáng, Y.X.J.; Wang, Y.; Ma, G.; Zhang, B. Medical imaging engineering and technology branch of the Chinese society of biomedical engineering expert consensus on the application of emergency mobile cabin CT. Quant. Imaging Med. Surg. 2020, 10, 2191-2208. [CrossRef]

178. Chen, H.; Yang, B.; Liu, J.; Zhou, X.N.; Yu, P.S. Mining Spatiotemporal Diffusion Network: A New Framework of Active Surveillance Planning. IEEE Access 2019, 7, 108458-108473. [CrossRef]

179. Cesario, M.; Lundon, M.; Luz, S.; Masoodian, M.; Rogers, B. Mobile support for diagnosis of communicable diseases in remote locations. In Proceedings of the 13th International Conference of the NZ Chapter of the ACM's Special Interest Group on Human-Computer Interaction (CHINZ ‘12), Dunedin, New Zealand, 2-3 July 2012; Association for Computing Machinery: New York, NY, USA, 2012; pp. 25-28. [CrossRef]

180. Dell, N.; Borriello, G. Mobile tools for point-of-care diagnostics in the developing world. In Proceedings of the 3rd ACM Symposium on Computing for Development (ACM DEV ‘13), Bangalore, India, 11-12 January 2013; Association for Computing Machinery: New York, NY, USA, 2013; pp. 1-10. [CrossRef]

181. Dey, S.K.; Howlader, A.; Deb, C. MobileNet Mask: A Multi-phase Face Mask Detection Model to Prevent Person-To-Person Transmission of SARS-CoV-2. In Proceedings of the International Conference on Trends in Computational and Cognitive Engineering. Advances in Intelligent Systems and Computing; Kaiser, M.S., Bandyopadhyay, A., Mahmud, M., Ray, K., Eds.; Springer: Singapore, 2021; Volume 1309. [CrossRef]

182. Egwolf, B.; Nicanor, A.O.P. Mobility-guided modeling of the COVID-19 pandemic in Metro Manila. Philipp. J. Sci. 2020, 149, 857-868.

183. Yang, B.; Guo, H.; Yang, Y.; Shi, B.; Zhou, X.; Liu, J. Modeling and mining spatiotemporal patterns of infection risk from heterogeneous data for active surveillance planning. In Proceedings of the 28th AAAI Conference on Artificial Intelligence, AAAI 2014, 26th Innovative Applications of Artificial Intelligence Conference, IAAI 2014 and the 5th Symposium on Educational Advances in Artificial Intelligence, EAAI 2014, Québec City, QC, Canada, 27-31 July 2014; AAAI Press: Palo Alto, CA, USA, 2014; Volume 1, pp. 493-499.

184. Tuarob, S.; Tucker, C.S.; Salathe, M.; Ram, N. Modeling Individual-Level Infection Dynamics Using Social Network Information. In Proceedings of the 24th ACM International on Conference on Information and Knowledge Management (CIKM '15), Melbourne, Australia, 18-23 October 2015; Association for Computing Machinery: New York, NY, USA, 2015; pp. 1501-1510. [CrossRef]

185. Worth, T.; Uzsoy, R.; Samoff, E.; Meyer, A.M.; Maillard, J.M.; Wendelboe, A.M. Modelling the response of a public health department to infectious disease. In Proceedings of the Winter Simulation Conference (WSC '10), Baltimore, MD, USA, 5-8 December 2010; pp. 2185-2198.

186. Clingan, C.A.; Dittakavi, M.; Rozwadowski, M.; Gilley, K.N.; Cislo, C.R.; Barabas, J.; Sandford, E.; Olesnavich, M.; Flora, C.; Tyler, J.; et al. Monitoring health care workers at risk for COVID-19 using wearable sensors and smartphone technology: Protocol for an observational mHealth study. JMIR Res. Protoc. 2021, 10, e29562. [CrossRef]

187. Yan, R.; Liao, W.; Cui, J.; Zhang, H.; Hu, Y.; Zhao, D. Multilingual COVID-QA: Learning towards Global Information Sharing via Web Question Answering in Multiple Languages. In Proceedings of the Web Conference 2021 (WWW '21), Ljubljana, Slovenia, 19-23 April 2021; ACM: New York, NY, USA, 2021; pp. 1-11. [CrossRef] 
188. Xu, Y.; Yang-Turner, F.; Volk, D.; Crook, D. NanoSPC: A scalable, portable, cloud compatible viral nanopore metagenomic data processing pipeline. Nucleic Acids Res. 2020, 48, W366-W371. [CrossRef] [PubMed]

189. Jones, K.; Munoz, B.; Rineer, J.; Bobashev, G.; Hilscher, R.; Rhea, S. On calibrating a microsimulation of patient movement through a healthcare network. In Proceedings of the Winter Simulation Conference (WSC '19), National Harbor, MD, USA, 8-12 December 2019; pp. 205-214. [CrossRef]

190. Sang, Z.; Qiu, Z.; Kong, Q.; Zou, Y. Optimal control strategy for an multi-regional epidemic model. In Proceedings of the 10th World Congress on Intelligent Control and Automation, Beijing, China, 6-8 July 2012; pp. 5007-5012. [CrossRef]

191. Peng, Z.; Xu, C.; Wang, H.; Huang, J.; Xu, J.; Chu, X. P2B-Trace: Privacy-Preserving Blockchain-based Contact Tracing to Combat Pandemics. In Proceedings of the 2021 International Conference on Management of Data (SIGMOD '21), Virtual Event, China, 20-25 June 2021; ACM: New York, NY, USA, 2021; pp. 1-5. [CrossRef]

192. Dhull, R.; Chava, D.; Kumar, D.V.; Prasad, K.M.; Samudrala, G.; Bhargav, M.V. Pandemic Stabilizer using Smartwatch. In Proceedings of the 2020 International Conference on Decision Aid Sciences and Application (DASA), Sakheer, Bahrain, 8-9 November 2020; pp. 860-866. [CrossRef]

193. Chunduri, S.; Ghaffar, M.; Lahijani, M.S.; Srinivasan, A.; Namilae, S. Parallel low discrepancy parameter sweep for public health policy. In Proceedings of the 18th IEEE/ACM International Symposium on Cluster, Cloud and Grid Computing (CCGrid '18), Washington District of Columbia, Washington, DC, USA, 1-4 May 2018; pp. 291-300. [CrossRef]

194. Susumpow, P.; Pansuwan, P.; Sajda, N.; Crawley, A.W. Participatory disease detection through digital volunteerism: How the doctorme application aims to capture data for faster disease detection in Thailand. In Proceedings of the 23rd International Conference on World Wide Web (WWW '14 Companion), Seoul, Korea, 7-11 April 2014; Association for Computing Machinery: New York, NY, USA, 2014; pp. 663-666. [CrossRef]

195. Utomo, F.S.; Maulana Baihaqi, W.; Mutiara, D.A.; Hermanto, N.; Widianto, R.A. People Under Surveillance Tracker Prototype Development with Bluetooth Low Energy to Suppress the COVID-19 Spread. In Proceedings of the 2020 2nd International Conference on Cybernetics and Intelligent System (ICORIS), Manado, Indonesia, 27-28 October 2020; pp. 1-6. [CrossRef]

196. Okyere, I.; Chuku, E.O.; Ekumah, B.; Angnuureng, D.B.; Boakye-Appiah, J.K.; Mills, D.J.; Babanawo, R.; Asare, N.K.; Aheto, D.W.; Crawford, B. Physical distancing and risk of COVID-19 in small-scale fisheries: A remote sensing assessment in coastal Ghana. Sci. Rep. 2020, 10, 22407. [CrossRef] [PubMed]

197. Mascarenhas, L.A.B.; Machado, B.A.S.; Rodrigues, L.d.A.P.; Hodel, K.V.S.; Santos, A.B.; Neves, P.R.F.; Andrade, L.P.C.D.S.; Soares, M.B.; de Andrade, J.B.; Badaró, R. Potential application of novel technology developed for instant decontamination of personal protective equipment before the doffing step. PLoS ONE 2021, 16, e0250854. [CrossRef]

198. Leon, M.I.; Iqbal, M.I.; Azim, S.M.; Al Mamun, K.A. Predicting COVID-19 infections and deaths in Bangladesh using Machine Learning Algorithms. In Proceedings of the 2021 International Conference on Information and Communication Technology for Sustainable Development (ICICT4SD), Dhaka, Bangladesh, 27-28 February 2021; pp. 70-75. [CrossRef]

199. Ye, Y.; Ding, Y. Prediction on COVID-19 via Logit Model for the Five Worst-Affected Countries in Global. In Proceedings of the 2nd International Conference on Computing and Data Science (CONFCDS 2021), Stanford, CA, USA, 28-30 January 2021; ACM: New York, NY, USA, 2021. [CrossRef]

200. Ahamad, M.K.; Bharti, A.K. Prevention from COVID-19 in India: Fuzzy Logic Approach. In Proceedings of the 2021 International Conference on Advance Computing and Innovative Technologies in Engineering (ICACITE), Greater Noida, India, 4-5 March 2021; pp. 421-426. [CrossRef]

201. Yoo, Y.; Suh, J.; Lee, Y.; Kang, S.; Kim, B.; Bahk, S. Privacy-preserving People Counting with Channel State Information. In Proceedings of the 2020 International Conference on Information and Communication Technology Convergence (ICTC), Jeju, Korea, 21-23 October 2020; pp. 753-755. [CrossRef]

202. Wazid, M.; Bera, B.; Mitra, A.; Das, A.K.; Ali, R. Private Blockchain-Envisioned Security Framework for AI-Enabled IoT-Based Drone-Aided Healthcare Services. In Proceedings of the Workshop on Drone Assisted Wireless Communications for 5G and Beyond (DroneCom'20), London, UK, 25 September 2020; ACM: New York, NY, USA, 2020; pp. 37-42. [CrossRef]

203. Ahmed, M.K.; Afifi, M.; Uskoković, V. Protecting healthcare workers during COVID-19 pandemic with nanotechnology: A protocol for a new device from Egypt. J. Infect. Public Health 2020, 13, 1243-1246. [CrossRef]

204. Duggal, S.; Jain, A. Proximity tracing method to reduce community spread of COVID 19. Int. J. Emerg. Technol. 2020, 11, 853-857.

205. Kassaye, S.G.; Spence, A.B.; Lau, E.; Bridgeland, D.M.; Cederholm, J.; Dimolitsas, S.; Smart, J. Rapid Deployment of a Free, Privacy-Assured COVID-19 Symptom Tracker for Public Safety During Reopening: System Development and Feasibility Study. JMIR Public Health Surveill. 2020, 6, e19399. [CrossRef] [PubMed]

206. Rao, L. Realization of Temperature Measurement by Passive Terahertz Imaging. In Proceedings of the 2020 13th UK-Europe-China Workshop on Millimetre-Waves and Terahertz Technologies (UCMMT), Tianjin, China, 29 August-1 September 2020; pp. 1-3. [CrossRef]

207. Kong, X.; Wang, K.; Wang, S.; Wang, X.; Jiang, X.; Guo, Y.; Shen, G.; Chen, X.; Ni, Q. Real-time Mask Identification for COVID-19: An Edge Computing-based Deep Learning Framework. IEEE Internet Things J. 2021. [CrossRef]

208. Minder, E.; Sombret, M.; Chardonnet, J.R.; Merienne, F. Rebirth-20—Relive After the COVID-19 and Keep Preventing Against it. In Proceedings of the 2021 IEEE Conference on Virtual Reality and 3D User Interfaces Abstracts and Workshops (VRW), Lisbon, Portugal, 27 March-1 April 2021; pp. 673-674. [CrossRef] 
209. Yakovyna, V.; Shakhovska, N.; Shakhovska, K.; Campos, J. Recommendation rules mining for reducing the spread of COVID-19 cases. In Proceedings of the 3rd International Conference on Informatics and Data-Driven Medicine, IDDM 2020, Växjö, Sweden, 19-21 November 2020; Volume 2753, pp. 219-229.

210. Steinhubl, S.R.; Marriott, M.P.; Wegerich, S.W. Remote sensing of vital signs: A wearable, wireless "band-aid" sensor withpersonalized analytics for improved Ebola patient care and worker safety. Glob. Health Sci. Pract. 2015, 3, 516-519. [CrossRef]

211. Khamis, A.; Kusy, B.; Chou, C.T.; McLaws, M.L.; Hu, W. RFWash: A Weakly Supervised Tracking of Hand Hygiene Technique. In Proceedings of the 18th ACM Conference on Embedded Networked Sensor Systems (SenSys '20), Virtual Event, Japan, 16-19 November 2020; ACM: New York, NY, USA, 2020; pp. 1-13. [CrossRef]

212. Yu, R.Z.; Li, Y.Q.; Peng, C.Z.; Ye, R.Z.; He, Q. Role of 5G-powered remote robotic ultrasound during the COVID-19 outbreak: Insights from two cases. Eur. Rev. Med. Pharmacol. Sci. 2020, 24, 7796-7800. [CrossRef]

213. Gupta, S.; Kapil, R.; Kanahasabai, G.; Joshi, S.S.; Joshi, A.S. SD-Measure: A Social Distancing Detector. In Proceedings of the 2020 12th International Conference on Computational Intelligence and Communication Networks (CICN), Bhimtal, India, 25-26 September 2020; pp. 306-311. [CrossRef]

214. Krishnan, R.S.; Kannan, A.; Manikandan, G.; KB, S.S.; Sankar, V.K.; Narayanan, K.L. Secured College Bus Management System using IoT for COVID-19 Pandemic Situation. In Proceedings of the 2021 Third International Conference on Intelligent Communication Technologies and Virtual Mobile Networks (ICICV), Tirunelveli, India, 4-6 February 2021; pp. $376-382$. [CrossRef]

215. Wang, S.; Li, Q.; Hou, J.; Jiang, J. Security Control Components for Epidemic Prevention Donation Management Blockchain. In Proceedings of the 2020 ACM Conference BSCI ‘20: 2nd International Symposium on Blockchain and Secure Critical Infrastructure Proceedings, Taipei, Taiwan, 5 October 2020; ACM: New York, NY, USA, 2020; pp. 73-84. [CrossRef]

216. Kraft, K.; Smart, W.D. Seeing is Comforting: Effects of Teleoperator Visibility in Robot-Mediated Health Care. In Proceedings of the Eleventh ACM/IEEE International Conference on Human Robot Interaction (HRI '16), Christchurch, New Zealand, 7-10 March 2016; pp. 11-18.

217. Vezeteu, P.V.; Năstac, D.I. Simulating the Evolution of Infectious Agents through Human Interaction. In Proceedings of the 2020 IEEE 26th International Symposium for Design and Technology in Electronic Packaging (SIITME), Pitesti, Romania, 21-24 October 2020; pp. 43-46. [CrossRef]

218. Ge, J.; Zhang, L.; Chen, Z.; Chen, G.; Peng, J. Simulation Analysis of Epidemic Trend for COVID-19 Based on SEIRS Model. In Proceedings of the 2020 IEEE 19th International Conference on Cognitive Informatics \& Cognitive Computing (ICCI*CC), Beijing, China, 26-28 September 2020; pp. 158-161. [CrossRef]

219. Andradóttir, S.; Chiu, W.; Goldsman, D.; Lee, M.L.; Tsui, K.L.; Fisman, D.N.; Sander, B.; Nizam, A. Simulation of strategies for containing pandemic influenza. In Proceedings of the Winter Simulation Conference (WSC '10), Baltimore, MD, USA, 5-8 December 2010; pp. 2221-2229.

220. Pandya, S.; Sur, A.; Kotecha, K. Smart epidemic tunnel: IoT-based sensor-fusion assistive technology for COVID-19 disinfection. Int. J. Pervasive Comput. Commun. 2020. [CrossRef]

221. Miller, E.; Banerjee, N.; Zhu, T. Smart homes that detect sneeze, cough, and face touching. J. Smart Health 2021, $19,100170$. [CrossRef] [PubMed]

222. Khayyat, M.; Munshi, R. SmartGate system: Automating the detection and control of COVID-19. In Proceedings of the 4th International Conference on Future Networks and Distributed Systems, ICFNDS 2020, St.Petersburg, Russia, 26-27 November 2020. [CrossRef]

223. Kumar, S.; Gautam, V.; Kumar, A.; Kumari, P. Social Distancing using Bluetooth Low Energy to Prevent the Spread of COVID-19. In Proceedings of the 2021 11th International Conference on Cloud Computing, Data Science \& Engineering (Confluence), Noida, India, 28-29 January 2021; pp. 563-567. [CrossRef]

224. Oransirikul, T.; Takada, H. Social Distancing Warning System at Public Transportation by Analyzing Wi-Fi Signal from Mobile Devices. In Proceedings of the 2020 ACM International Joint Conference on Pervasive and Ubiquitous Computing and Proceedings of the 2020 ACM International Symposium on Wearable Computers (UbiComp/ISWC '20 Adjunct), Virtual Event, Mexico, 12-16 September 2020; ACM: New York, NY, USA, 2020; pp. 267-271. [CrossRef]

225. Biri, A.; Jackson, N.; Thiele, L.; Pannuto, P.; Dutta, P. SociTrack: Infrastructure-Free Interaction Tracking through Mobile Sensor Networks. In Proceedings of the 26th Annual International Conference on Mobile Computing and Networking (MobiCom '20), London, UK, 21-25 September 2020; ACM: New York, NY, USA, 2020; pp. 1-14. [CrossRef]

226. Rajakumar, K.; Reda, H.S.; Gebregergs Tesfay, K.; Meles, M. Solar Power based Intelligent System for Hand wash cum Dryer to Conflict the Outbreak of COVID-19. In Proceedings of the 2020 3rd International Conference on Intelligent Sustainable Systems (ICISS), Thoothukudi, India, 3-5 December 2020; pp. 1398-1403. [CrossRef]

227. Evans, K.D.; Yang, Q.; Liu, Y.; Ye, R.; Peng, C. Sonography of the Lungs: Diagnosis and Surveillance of Patients with COVID-19. J. Diagn. Med Sonogr. 2020, 36, 370-376. [CrossRef]

228. Zhiming, N.; Song, Q. System design of safety road network in urban morphology prevention during COVID-19 based on digital simulation technology. In Proceedings of the 2020 2nd International Conference on Big Data Engineering, BDE 2020, Shanghai, China, 29-31 May 2020; pp. 131-137. [CrossRef] 
229. Jadidi, M.M.; Moslemi, P.; Jamshidiha, S.; Masroori, I.; Mohammadi, A.; Pourahmadi, V. Targeted Vaccination for COVID-19 Using Mobile Communication Networks. In Proceedings of the 2020 11th International Conference on Information and Knowledge Technology (IKT), Tehran, Iran, 22-23 December 2020; pp. 93-97. [CrossRef]

230. Wang, L.; Chen, J.; Marathe, M. TDEFSI: Theory-guided Deep Learning-based Epidemic Forecasting with Synthetic Information. ACM Trans. Spat. Algorithms Syst. 2020, 6, 1-39. [CrossRef]

231. Sivaraman, M.; Virues-Ortega, J.; Roeyers, H. Telehealth mask wearing training for children with autism during the COVID-19 pandemic. J. Appl. Behav. Anal. 2021, 54, 70-86. [CrossRef] [PubMed]

232. Ren, X.; Zhai, Y.; Song, X.; Wang, Z.; Dou, D.; Li, Y. The Application of Mobile Telehealth System to Facilitate Patient Information Presentation and Case Discussion. Telemed. e-Health 2020, 26, 725-733. [CrossRef]

233. Alado, D.B.; Plata, I.T.; Bartolome, B.B. The development of the geographical information system (GIS)-based mapping of infectious diseases using spatial data analysis. Int. J. Adv. Trends Comput. Sci. Eng. 2019, 8, 3577-3583. [CrossRef]

234. Andrasto, T.; Arief, U.M.; Sukamta, S.; Sulistyawan, V.N.; Sarwono, E.; Alfian, A.A.; Wicaksono, P.; Amelia, P.N.; Putra, A.D.H. The effectiveness of disinfectant spraying based on drone technology. IOP Conf. Ser. Earth Environ. Sci. 2021, 700, 012012. [CrossRef]

235. Freire, J.D.; Montenegro, J.R.; Mejia, H.A.; Guzman, F.P.; Bustamante, C.E.; Velastegui, R.X.; Guachi, L.D.L.A. The Impact of Histogram Equalization and Color Mapping on ResNet-34's Overall Performance for COVID-19 Detection. In Proceedings of the 2021 4th International Conference on Data Storage and Data Engineering (DSDE '21), Barcelona, Spain, 18-20 February 2021; ACM: New York, NY, USA, 2021; pp. 1-7. [CrossRef]

236. Tresenriter, M.A.; Holdaway, J.A.; Killeen, J.A.; Chan, T.A.; Dameff, C. The Implementation of an Emergency Medicine Telehealth System during a Pandemic. J. Emerg. Med. 2021, 60, 548-553. [CrossRef]

237. Lan, R.; Lieberman, M.D.; Samet, H. The picture of health: Map-based, collaborative spatio-temporal disease tracking. In Proceedings of the First ACM SIGSPATIAL International Workshop on Use of GIS in Public Health (HealthGIS '12), Redondo Beach, CA, USA, 6 November 2012; Association for Computing Machinery: New York, NY, USA, 2012; pp. 27-35. [CrossRef]

238. Guo, R.; CHEN, B.; Yang, M.; LI, Z. The Study of Colleges Students Returning to Campus under the Epidemic Situation Based on GIS. In Proceedings of the EMGIS'20: Emergency Management Using GIS, Seattle, WA, USA, 3-6 November 2020; ACM: New York, NY, USA, 2020; pp. 1-6. [CrossRef]

239. Lunz, D.; Batt, G.; Ruess, J. To quarantine, or not to quarantine: A theoretical framework for disease control via contact tracing. J. Epidemics 2021, 34, 100428. [CrossRef] [PubMed]

240. Kasaie, P.; Kelton, W.D.; Vaghefi, A.; Naini, S.G.R.J. Toward optimal resource-allocation for control of epidemics: An agent-basedsimulation approach. In Proceedings of the Winter Simulation Conference (WSC '10), Baltimore, MD, USA, 5-8 December 2010; pp. 2237-2248.

241. Qi, F.; Du, F. Tracking and visualization of space-time activities for a micro-scale flu transmission study. Int. J. Health Geogr. 2013, 12, 6. [CrossRef] [PubMed]

242. Ju, W.; Ayalon, S.Y.; Mandel, I.; Saldarini, F.; Friedman, N.; Sibi, S.; Pereira, J.D.Z.; Ortiz, J. Tracking Urban Mobility and Occupancy under Social Distancing Policy. Digit. Gov. Res. Pract. 2020, 1, 32. [CrossRef]

243. Elmesalawy, M.M.; Salama, A.I.; Anany, M.G. Tracy: Smartphone-based Contact Tracing Solution that Supports Self-investigation to Limit the Spread of COVID-19. In Proceedings of the 2020 2nd Novel Intelligent and Leading Emerging Sciences Conference (NILES), Giza, Egypt, 24-26 October 2020; pp. 623-628. [CrossRef]

244. Péron, M.; Bartlett, P.L.; Becker, K.H.; Helmstedt, K.; Chadès, I. Two Approximate Dynamic Programming Algorithms for Managing Complete SIS Networks. In Proceedings of the 1st ACM SIGCAS Conference on Computing and Sustainable Societies (COMPASS '18), Menlo Park, San Jose, CA, USA, 20-22 June 2018; Association for Computing Machinery: New York, NY, USA, 2018; pp. 1-10. [CrossRef]

245. Hao, Q.; Chen, L.; Xu, F.; Li, Y. Understanding the Urban Pandemic Spreading of COVID-19 with Real World Mobility Data. In Proceedings of the 26th ACM SIGKDD Conference on Knowledge Discovery \& Data Mining (KDD’20), Virtual Event, USA, 23-27 August 2020; ACM: New York, NY, USA, 2020; pp. 3485-3492. [CrossRef]

246. Shcherbak, V.; Gryshchenko, I.; Ganushchak-Yefimenko, L.; Nifatova, O.; Tkachuk, V.; Kostiuk, T.; Hotra, V. Using a sharingplatform to prevent a new outbreak of COVID-19 pandemic in rural areas. Glob. J. Environ. Sci. Manag. 2021, 7, 155-170. [CrossRef]

247. Knyazkov, M.M.; Polyakov, A.V.; Usov, V.M. Using machine vision for functionality expansion of mini robots decontaminating medical personnel premises in conditions of COVID-19 epidemic. Int. Arch. Photogramm. Remote Sens. Spat. Inf. Sci. 2021, 54, 143-147. [CrossRef]

248. Herman, T.; Pemmaraju, S.V.; Segre, A.M.; Polgreen, P.M.; Curtis, D.E.; Fries, J.; Hlady, C.; Severson, M. Wireless applications for hospital epidemiology. In Proceedings of the 1st ACM International Workshop on Medical-Grade Wireless Networks (WiMD ‘09), New Orleans, LA, USA, 18 May 2009; Association for Computing Machinery: New York, NY, USA, 2009; pp. 45-50. [CrossRef] 